\title{
De Limburgse arbeidmarkt 1999-2004
}

Citation for published version (APA):

Diephuis, B. J., van Eijs, P. W. L. J., de Grip, A., Nekkers, G. J. A., \& Sanders, J. M. A. F. (2000). De Limburgse arbeidmarkt 1999-2004: Statistische bijlage. Researchcentrum voor Onderwijs en Arbeidsmarkt, Faculteit der Economische Wetenschappen. ROA Reports No. 4B https://doi.org/10.26481/umarep.200004B

Document status and date:

Published: 01/01/2000

DOI:

10.26481/umarep.200004B

Document Version:

Publisher's PDF, also known as Version of record

\section{Please check the document version of this publication:}

- A submitted manuscript is the version of the article upon submission and before peer-review. There can be important differences between the submitted version and the official published version of record.

People interested in the research are advised to contact the author for the final version of the publication, or visit the DOI to the publisher's website.

- The final author version and the galley proof are versions of the publication after peer review.

- The final published version features the final layout of the paper including the volume, issue and page numbers.

Link to publication

\footnotetext{
General rights rights.

- You may freely distribute the URL identifying the publication in the public portal. please follow below link for the End User Agreement:

www.umlib.nl/taverne-license

Take down policy

If you believe that this document breaches copyright please contact us at:

repository@maastrichtuniversity.nl

providing details and we will investigate your claim.
}

Copyright and moral rights for the publications made accessible in the public portal are retained by the authors and/or other copyright owners and it is a condition of accessing publications that users recognise and abide by the legal requirements associated with these

- Users may download and print one copy of any publication from the public portal for the purpose of private study or research.

- You may not further distribute the material or use it for any profit-making activity or commercial gain

If the publication is distributed under the terms of Article $25 \mathrm{fa}$ of the Dutch Copyright Act, indicated by the "Taverne" license above, 


\section{Statistische Bijlage \\ De Limburgse arbeidsmarkt 1999-2004}

ROA-R-2000/4B

Researchcentrum voor Onderwijs en Arbeidsmarkt

Faculteit der Economische Wetenschappen en Bedrijfskunde Universiteit Maastricht

Maastricht, maart 2000 
Niets uit deze uitgave mag worden verveelvoudigd en/of openbaar gemaakt door middel van druk, fotokopie, microfilm, of op welke wijze ook, zonder voorafgaande schriftelijke toestemming van de directeur van het Researchcentrum voor Onderwijs en Arbeidsmarkt. In geval van overname van het datamateriaal moet telkens duidelijk als bron worden vermeld: "Researchcentrum voor Onderwijs en Arbeidsmarkt" of "ROA". Van publicaties waarin gebruik wordt gemaakt van gegevens uit deze Statistische Bijlage ontvangen wij gaarne een exemplaar.

Hoewel de grootst mogelijke zorg is besteed aan de inhoud van dit rapport, kan het ROA in generlei opzicht verantwoordelijkheid op zich nemen voor eventuele onvolledigheden of onjuistheden. 


\section{Inhoud}

Bladzijde

Voorwoord

1 De werkgelegenheidsstructuur in Limburg

Tabellen

1.1 Aantal werkenden per bedrijfssector, Limburg, gemiddelde 1997-1998 1

1.2 Aantal werkenden per bedrijfssector, Zuid-Limburg, gemiddelde 1997-1998 3

1.3 Aantal werkenden per bedrijfssector, Noord- en Midden-Limburg, gemiddelde 1997-1998

1.4 Belangrijkste opleidingsniveaus van de werkenden per bedrijfssector, Limburg, gemiddelde 1997-1998

1.5a Percentage jongeren (15-29 jaar) per bedrijfssector, Limburg, gemiddelde 1997-1998

1.5b Percentage ouderen (50-64 jaar) per bedrijfssector, Limburg, gemiddelde 1997-1998

1.6 Percentage vrouwen per bedrijfssector. Limburg, gemiddelde 1997-1998

1.7 Percentage flexibel werk per bedrijfssector, Limburg, gemiddelde 1997-1998

1.8 Percentage deeltijdwerk per bedrijfssector, Limburg, gemiddelde 1997-1998

1.9 Percentage zelfstandigen per bedrijfssector, Limburg, gemiddelde 1997-1998

1.10 Aantal werkenden per beroepsgroep, Limburg, gemiddelde 1997-1998

1.11 Aantal werkenden per beroepssegment, Zuid-Limburg. gemiddelde 1997-1998

1.12 Aantal werkenden per beroepssegment, Noord-en Midden-Limburg, gemiddelde 1997-1998

1.13 Belangrijkste opleidingsniveaus van de werkenden per beroepssegment, Limburg. gemiddelde 1997-1998

1 14a Percentage jongeren (15-29 jaar) per beroepssegment, Limburg. gemiddelde 1997-1998

$114 \mathrm{~b}$ Percentage ouderen (50-64 jaar) per beroepssegment, Limburg, gemiddelde 1997-1998

1.15 Percentage vrouwen per beroepssegment. Limburg, gemiddelde 1997-1998 20

1.16 Percentage flexibel werk per beroepssegment, Limburg. gemiddelde 1997-1998 21

117 Percentage deeltijdwerk per beroepssegment, Limburg. gemiddelde 1997-1998 22

1.18 Percentage zelfstandigen per beroepssegment, Limburg. gemiddelde 1997-1998 23

1.19 Aantal werkenden per opleidingstype, Limburg. gemiddelde 1997-1998 24

1.20 Aantal werkenden per oplerdingssector, Zuid-Limburg, gemiddelde 1997-1998 25

1.21 Aantal werkenden per opleidingssector, Noord- en Midden-Limburg, gemiddelde 1997-1998

1.22 Arbeidsmarktpositie potentiële beroepsbevolking naar opleidingstype, Limburg, gemiddelde 1997-1998

1.23a Percentage jongeren (15-29 jaar) per opleidingssector, Limburg, gemiddelde 1997-1998

1.23b Percentage ouderen (50-64 jaar) per opleidingssector, Limburg, gemiddelde 1997-1998 
1.24 Percentage vrouwen per opleidingssector, Limburg, gemiddelde 1997-1998

1.25 Percentage flexibel werk per opleidingssector, Limburg. gemiddelde 1997-1998

1.26 Percentage deelfijdwerk per opleidingssector, Limburg, gemiddelde 1997-1998

127 Percentage zelfstandigen per opleidingssector, Limburg, gemiddelde 1997-1998

\section{Actuele discrepanties op de Limburgse arbeidsmarkt}

\section{Tabellen}

2.1 Openstaande vacatures per bedrijfssector, Limburg, april 1999

2.2 Openstaande vacatures per beroepssegment, Limburg, april 1999

2.3 Openstaande vacatures per opleidingssector, Limburg, april 1999

2.4 Niet-werkende werkzoekenden per beroepssegment, Limburg, april 1999

2.5 Niet-werkende werkzoekenden per beroepssegment en bemiddelingsfase, Limburg, april 1999

2.6 Kenmerken niet-werkende werkzoekenden per beroepssegment, Limburg, april 1999

2.7 Niet-werkende werkzoekenden per opleidingssector, Limburg, april 1999

2.8 Niet-werkende werkzoekenden per opleidingssector en bemiddelingsfase, Limburg, april 1999

2.9 Kenmerken niet-werkende werkzoekenden per opleidingssector, Limburg, april 1999

2.10 Discrepanties per bedrijfssector, Limburg, april 1999

2.11 Discrepanties per beroepssegment. Limburg, april 1999

2.12 Discrepanties per opleidingssector, Limburg, april 1999

3 De Limburgse arbeidsmarkt in 2000

\section{Tabellen}

31 Verwachte uitbreidingsvraag per bedrijfssector, Limburg, 2000

3.2 Verwachte uitbreidingsvraag per beroepsgroep, Limburg, 2000

3.3 Verwachte vervangingsvraag per beroepsgroep. Limburg, 2000

3.4 Verwachte baanopeningen per beroepsgroep, Limburg, 2000

3.5 Verwachte arbeidsmarktinstroom van schoolverlaters naar beroepsgroep. Limburg, 2000

3.6 Indicator Toekomstige Arbeidsmarktpositie naar Beroep (ITAB) en Indicator Toekomstige Knelpunten in de personeelsvoorziening naar Beroep (ITKB), Lumburg. 2000

3.7 Venwachte uitbreidingsvraag per opleidingstype, Limburg, 2000

3.8 Verwachte vervangingsvraag per opleidingstype, Limburg, 2000

3.10 Verwachte arbeidsmarktinstroom van schoolverlaters per opleidingstype, Limburg, 2000

3.11 Indicator Toekomstige Arbeidsmarktperspectieven (ITA) en Indicator Toekomstige Knelpunten in de Personeelsvoorziening (ITKP) naar opleiding, Limburg, 2000 


\section{De Limburgse arbeidsmarkt tot 2004}

\section{Tabellen}

4.1 Verwachte uitbreidingsvraag per bedrijfssector, Limburg, 1999-2004 75

4.2 Verwachte uitbreidingsvraag per beroepsgroep, Limburg, 1999-2004 76

4.3 Venwachte vervangingsvraag per beroepsgroep, Limburg, 1999-2004 79

4.4 Verwachte baanopeningen per beroepsgroep, Limburg, 1999-2004 82

4.5 Verwachte uitbreidingsvraag per opleidingstype. Limburg, 1999-2004 85

4.6 Verwachte vervangingsvraag per opleidingstype, Limburg, 1999-2004 87

4.7 Verwachte baanopeningen per opleidingstype, Limburg, 1999-2004 89

4.8 Verwachte arbeidsmarktinstroom van schoolverlaters per opleidingstype, Limburg, 1999-2004

4.9 Indicator Toekomstige Arbeidsmarktperspectieven (ITA) en Indicator Toekomstige Knelpunten in de Personeelsvoorziening (ITKP) naar opleiding, Limburg, 1999-2004 


\section{Voorwoord}

Deze Statistische Bijlage bij het rapport De Limburgse arbeidsmarkt 1999-2004 geeft een systematisch overzicht van de verwachte arbeidsmarktontwikkelingen en de actuele arbeidsmarktgegevens die ten grondslag liggen aan het hoofdrapport. Op basis van de in hel kader van RAIL gegenereerde en verzamelde kwantitatieve informatie wordt een zo volledig mogelijk beeld gegeven, verbijzonderd naar 13 bedrijfssectoren, 127 beroepsklassen en 113 opleidingstypen. Daarbij wordt gebruik gemaakt van de vanuit het informatiesysteem Onderwijs-Arbeidsmarkt van het ROA gegenereerde gegevens over de actuele werkgelegenheidsstructuur en de op korte en middellange termijn verwachte arbeidsmarktontwikkelingen. Deze arbeidsmarktinformatie wordt aangevuld met informatie over de niet-werkende werkzoekenden en de openstaande vacatures. Deze informatie is voor een belangrijk deel gebaseerd op het Primair Gemeenschappelijk Informatiesysteem van Arbeidsvoorziening Limburg. Daarnaast is gebruik gemaakt van de CBS-vacature-enquête. Het hoofdrapport De Limburgse arbeidsmarkt 1999-2004 geeft het kader aan waarin de tabellen in deze Statistische Bijlage moeten worden geplaatst.

Deze Statistische Bijlage bestaat uit vier delen. In de eerste twee delen staat de actuele arbeidsmarktsituatie centraal. In het eerste deel wordt een beeld geschetst van de werkgelegenheidsstructuur in de provincie Limburg. Er wordt achtereenvolgens informatie gepresenteerd over de persoons- en functiekenmerken van de werkzame beroepsbevolking in Limburg naar bedrijfssector, beroepsgroep, opleidingstype en subregio. Tevens wordt telkens een vergelijking met de landelijke of provinciale structuur gegeven.

In het tweede deel staan de actuele discrepanties centraal. Ten eerste wordt aandacht geschonken aan de openstaande vacatures. Er wordt informatie gepresenteerd over het aantal openstaande vacatures, de vacaturegraad en het percentage langdurig openstaande vacatures naar bedrijfssector, beroepssegment en opleidingssector'. Verder wordt er informatie gegeven over de niet-werkende werkzoekenden op de Limburgse arbeidsmarkt. Er wordt informatie gepresenteerd over het aantal niet-werkende werkzoekenden, het percentage langdurig werkzoekenden, de persoonskenmerken en de bemiddelbaarheid van de niet-werkende werkzoekenden naar beroepssegment en opleidingssector. Het tweede deel eindigt met een confrontatie van de aantallen openstaande vacatures en niet-werkende werkzoekenden. Dit maakt het mogelijk de kwantitatieve en kwalitatieve discrepanties op de Limburgse arbeidsmarkt in beeld te brengen. Hiervoor worden twee indicatoren gepresenteerd. De indicator voor de arbeidsmarktkrapte naar bedrijfssector, beroepssegment of opleidingssector geeft de verhouding tussen het aantal openstaande vacatures en het aantal direct bemiddelbare werkzoekenden weer. Wanneer de indicator voor de arbeidsmarktkrapte groter is dan een, is er sprake van een tekort. Wanneer de indicator daarentegen kleiner is dan éen, dan is er sprake van (enige) ruimte op het betreffende arbeidsmarktsegment. De knelpuntsindicator naar beroepssegment of opleidingssector geeft aan in hoeverre een tekort aan direct inzetbaar aanbod een kwantitatief of een kwalitatief karakter heeft. De indicator geeft de verhouding weer tussen het aantal openstaande vacatures dat niet door direct inzetbare werkzoekenden kan worden ingevuld en het aantal niet-werkende werkzoekenden met een wat grotere afstand tot de arbeidsmarkt. Naarmate deze verhouding groter wordt, heeft het tekort een meer kwantitatief karakter; het aantal niet-werkende werkzoekenden schiet eenvoudigweg tekort om aan de openstaande

1. Achterin het hoofdrapport De Limburgse arbeidsmarkt 1999-2004 worden de gehanteerde centrale begrippen gedefinieerd. 
De in de delen drie en vier gepresenteerde tabellen geven een beeld van de te verwachten toekomstige ontwikkelingen op de Limburgse arbeidsmarkt naar beroepsgroep en opleidingstype. In deel drie worden de prognoses voor de korte termijn (d.w.z. voor 2000) gepresenteerd. terwijl in deel vier een overzicht wordt gegeven van de prognoses voor de middellange termijn (tot 2004). De prognoses hebben zowel betrekking op de vraagzijde als op de aanbodzijde van de arbeidsmarkt.

Aan de vraagzijde wordt een onderscheid gemaakt tussen de uitbreidingsvraag en de vervangingsvraag, die tezamen de baanopeningen voor nieuwkomers op de arbeidsmarkt vormen. De Indicator Toekomstige Arbeidsmarktperspectieven (ITA) en de Indicator Toekomstige Arbeidsmarktperspectieven naar Beroep (ITAB) geven de verhouding tussen vraag en aanbod weer. Daarbij moet worden bedacht dat een aanbodoverschot van mensen met een bepaaide opleidingsachtergrond of beroep niet per se tot werkloosheid van de betrokkenen hoeft te leiden. Een gebrekkige aansluiting tussen vraag en aanbod kan zich ook manifesteren in een hogere kans op werk buiten het eigen vakgebied of beneden het gevolgde opleidingsniveau, een lagere beloning, meer kans op een tijdelijk contract, etc. De Indicator Toekomstige Knelpunten in de Personeelsvoorziening (ITKP) en de Indicator Toekomstige Knelpunten in de Personeelsvoorziening naar Beroep (ITKB) bezien de implicaties van de verhouding tussen vraag en aanbod vanuit het gezichtspunt van de werkgever. Ook hierbij moet bedacht worden dat een aanbodtekort niet per se tot openstaande vacatures behoeft te leiden, maar ook aanpassingsprocessen op gang kan brengen.

De prognoses voor de perspectieven en knelpunten naar beroepsgroep hebben alleen betrekking op de elementaire, lagere en middelbare beroepen, terwijl de prognoses voor de perspectieven en knelpunten naar opleidingstype alleen betrekking hebben op het Basisonderwijs, de VMBO-opleidingen en de opleidingen op MBO-niveau. Voor de hogere beroepen en opleidingen heeft de arbeidsmarkt immers doorgaans een meer landelijk karakter. Voor de bedrijfssectoren en hogere beroepen en opleidingen worden alleen prognoses voor de uitbreidings- en vervangingsuraag en de daaruit resulterende baanopeningen gepresenteerd. Het is belangrijk op te merken dat dit aantal baanopeningen op zichzelf geen informatie geeft over de verwachte perspectieven en knelpunten, aangezien alleen de vraagzijde wordt belicht en geen confrontatie met de verwachte stromen aan de aanbodzijde van de arbeidsmarkt wordt gemaakt.

In deel vier is tevens informatie opgenomen over de structurele positie van opleidingen op de arbeidsmarkt. Het betreft hier de conjunctuurgevoeligheid van de werkgelegenheid en de uitwijkmogelijkheden op de arbeidsmarkt. Deze indicatoren hebben tot doel het perspectief in een breder kader te plaatsen. De prognoses van vraag en aanbod zijn uiteraard altijd aan onzekerheid onderhevig. Bovendien zal een schoolverlater doorgaans een lange tijd op de arbeidsmarkt vertoeven. De structurele kenmerken beogen daarom een indicatie te geven van de risico's die men op een bepaald arbeidsmarktsegment loopt. Zo geeft de conjunctuurgevoeligheid aan in welke mate de werkgelegenheid voor het betreffende opleidingstype aan schommelingen onderhevig is, terwijl de uitwijkmogelijkheden aangeven in welke mate de werkenden afhankelijk zijn van de werkgelegenheidsontwikkelingen in één beroep of juist uit kunnen wijken naar meerdere beroepsgroepen.

In de meeste tabellen wordt ook een kwalitatieve typering gegeven van de gepresenteerde informatie. Bij de actuele arbeidsmarktinformatie wordt tevens een indicatie gegeven van de trend in de afgelopen jaren. Bij de informatie over beroepsgroepen en opleidingstypen gaat het 
hierbij in principe om de ontwikkeling in de periode 1993-1998. De informatie over de trendmatige ontwikkeling heeft meestal betrekking op de ontwikkeling van het aandeel van de desbetreffende categorie. Alleen bij de tabellen 1.1, 1.10 en 1.19 gaat het om de ontwikkeling van het aantal werkenden.

De arbeidsmarktgegevens met betrekking tot de werkzame en niet-werkzame bevolking in het eerste deel zijn afkomstig uit de Enquête Beroepsbevolking (EBB) van het Centraal Bureau voor de Statistiek (CBS). Om de robuustheid van de informatie te vergroten, hebben de gepresenteerde gegevens telkens betrekking op het gemiddelde van de jaren 1997 en 1998 . Om de herkenbaarheid van individuele respondenten te voorkomen, heeft het CBS de restrictie gesteld dat bij het publiceren van tweejaarlijkse gemiddelden alleen cijfers over categorieën mogen worden gepresenteerd die betrekking hebben op minimaal 2.500 personen. In deel twee heeft het ROA, in het licht van de betrouwbaarheid van de informatie, de aantallen openstaande vacatures en niet-werkende werkzoekenden afgerond op 25-tallen. Bovendien is er een ondergrens van 25 gehanteerd. In de delen drie en vier is een ondergrens van 2.000 personen gehanteerd. Wanneer er in een beroepsgroep of opleidingstype minder dan 2.000 mensen werkzaam zijn, worden alleen kwalitatieve typeringen van de verwachte ontwikkelingen gepresenteerd.

De informatie naar bedrijfssector is gebaseerd op Standaard Bedriffsindeling 1993 (SB|'93) van het CBS. De informatie naar beroepsgroep is gebaseerd op de Standaard Beroepsclassificatie 1992 (SBC'92) van het CBS. Hierbij is de 3-digitcode van het CBS gebruikt, waarbij code 471 is uitgesplitst in Bakkers en slagers en Procesoperators. Bovendien is bij de elementaire beroepen een uitsplitsing gemaakt naar zes beroepsgroepen. Tevens is afgeweken van de door het CBS gehanteerde namen. In plaats daarvan worden kortere beroepsnamen gebruikt. Voor de informatie naar opleidingstype is door het ROA een eigen classificatie ontwikkeld waarin opleidingen geclusterd zijn die in hoge mate hetzelfde beroependomein kennen. Deze classificatie is overigens wel gekoppeld aan de Standaard Onderwijs Indeling (SOI) van het CBS. In deze Statistische Bijlage wordt overigens gebruik gemaakt van een opleidingenclassificatie waarin de naamgeving aansluit bij de nieuwe classificatiestructuur. In de begrippenlijst achterin het hoofdrapport De Limburgse arbeidsmarkt 1999-2004 wordt een relatie gelegd tussen de oude kwalificatiestructuur en de bijbehorende benamingen en de nieuwe kwalificatiestructuur en de bijbehorende opleidingsaanduidingen zoals die zijn geformuleerd in de Wet Educatie en Beroepsonderwijs (WEB). 
Tabel 1.1

Aantal werkenden per bedrijfssector, Limburg, gemiddelde 1997-1998

Bedrififssector

aantal Limburg t.o.v. trend

Nederland

$1993-1996$

Landbouw en visserij

15.500

Tuinbouw

Veehouderij

7.000

8.000

hoog

constant

Akkerbouw, bosbouw en visserij

gemuddeld

sterk dalend

Voeding

9.500

Vlees-en visverwerking

Overige voedingingsproducten

Drank en tabaksproducten

Chemie

16.000

Basıschemie

Eindproducten chemie

Kunststofverwerking

$\begin{array}{rll}10.000 & \text { erg hoog } & \text { stijgend } \\ 4.500 & \text { erg hoog } & \text { constant }\end{array}$

Metaal en elektrotechniek

44.500

Basismetaal

2.500

Metaalproducten

11.000

6.500

Machine-industrie

Elektrotechniek

15.000

Transportmiddelen

9.500

erg hoog

erg hoog

gemiddeld

erg hoog

erg hoog

sterk dalend

constant

36.500

Textiel

Hout- en bouwmaterialen

4.000

23.000

3.500

erg hoog

erg hoog

stijgend

Papier

Grafische industrie

5.500

erg hoog

laag

5.000

gemiddeld

sterk dalend constant sterk dalend dalend stijgend

Energie

34000

Boun

Exploitatie van onroerend goed

31.000

gemiddeld

stijgend

3.000

gemidideld

stijgend

Handel en reparatie

62.500

laag

stijgend

Transport en communicatie

26.500

Scheep-en luchtvaart

Weg-en railvervoer

Communicatie

19.000

gemiddeld

constant

7.500

gemiddeld

sterk stijgend

Bank-en verzekeringswezen

15.000

Bankwezen

Verzekeringswezen

7.500

laag

gemiddeld

sterk stijgend

stijgend 
Tabel 1.1 (vervolg)

Aantal werkenden per bedrijfssector, Limburg, gemiddelde 1997-1998

Bedriffssector

aantal Limburg t.o.v. trend

Nederland 1993-1998

Horeca en zakelijke dienstvertening

Horeca

Zakelijke dienstverlening

Overige commerciele dienstverlening

Kwartaire diensten

Gezondsheidszorg

Overige kwartaire diensten

Overheid en onderwijs

Onderwijs

Overheid

Totaal
58.000

$\begin{array}{lll}14.000 & \text { hoog } & \text { stijgend } \\ 33.500 & \text { laag } & \text { stijgend } \\ 10.500 & \text { gemiddeld } & \text { stijgend }\end{array}$

69.500

63.500 gemiddeld stijgend

6.000 zeer laag constant

61.500

27.000 gemiddeld

34.500

gemiddeld

constant

stijgend

Bron: CBS/ROA 
Tabel 1.2

Aantal werkenden per bedrijtssector, Zuid-Limburg, gemiddelde 1997-1998

Bedrijfsector

aantal

Zuid-Limburg L.O.V.

Limburg totaal

Landbouw en visserij

2.500

4.500

erg laag

Voeding

12.000

Chemie

28.500

Metaal en elektrotechniek

11.500

Overige industrie

2.500

gemiddeld

Energie

18.000

Bouw en onroerend goed

29.500

Handel

14.500

communicatie

10.000

erg hoog

Bank-en verzekeringswezen

37.000

laag

gemiddeld

gemiddeld

gemiddeld

gemiddeld

Horeca, reparatie en zakelijke dienstverlening

41.000

gemidideld

Kwartaire diensten

38.500

hoog

hoog

Overheid en onderwijs

256.500

Totaal

hoog

hoog

\section{Bron: CBS/ROA}

Toelichting:

De tabellen 1.2 en 1.3 gaan uit van de oude bedrijfssectorindeling zoals deze ook werd gebruikt in Do Limburgse arbeidsmarkt 1998-2002. Dit is een andere bedrijfssectorindeling dan die in tabel 1.1. De gewijzigde classificatie, waarbij een aantal beroepen van sector wisselt, heeft gevolgen voor de sectoren: Metaal en elektrotechniek. Overige industrie. Handel. Horeca, reparatie en zakelijke dienstverlening alsmede Kwartaire diensten. De verschuivingen hebben tot gevolg dat subregionale optellingen niet in alle gevallen overeenkomen met de Limburgse totalen in tabel 1.1. Voor sectoren waarin geen classificatie-verandering heeft plaatsgevonden, geldt dat afwijkingen van het total te wijten zijn aan de afronding van gepresenteerde aantallen. 
Tabel 13

Aantal werkenden per bedrififssector, Noord- en Midden-Limburg, gemiddelde 1997-1998

Bedriffssector

aantal

Noord-en

Midden-Limburg

to.v. Limburg totaa

Landbouw en visserij
Voeding
Chemie
Metaal en elektrotechniek
Overige industrie
Energie
Bouw en onroerend goed
Handel
Transport en communicatie
Bank- en verzekeringswezen
Horeca, reparatie en zakelijke dienstverlening
Kwartaire diensten
Overheid en onderwijs

Totaal

$\begin{aligned} 13.000 & \text { erg hoog } \\ 5.000 & \text { gemiddeld } \\ 4.000 & \text { erg laag } \\ 30.000 & \text { hoog } \\ 10.000 & \text { gemiddeld } \\ 2.500 & \text { gemiddeld } \\ 15.500 & \text { gemiddeld } \\ 26.000 & \text { gemiddeld } \\ 12.000 & \text { gemiddeld } \\ 4.500 & \text { laag } \\ 23.500 & \text { laag } \\ 30.000 & \text { laag } \\ 21.500 & \text { laag }\end{aligned}$

201.500

\section{Bron: CBS/ROA}

Toelichting:

De tabellen 1.2 en 1.3 gaan uit van de oude bedrijssectorindeling zoals deze ook werd gebruikt in De Limburgse arbeidsmarkt 1998-2002. Dit is een andere bedrijissectorindeling dan die in tabel 11 . De gewijzigde classificatie, waarbij een aantal beroepen van sector wisselt, heeft gevolgen voor de sectoren: Metaal en elektrotechniek, Overige industrie, Handel. Horeca, reparatıe en zakelijke dienstverlening alsmede Kwartaire diensten. De verschuivingen hebben tot gevolg dat subregionale optellingen niet in alle gevallen overeenkomen met de Limburgse totalen in tabel 1.1. Voor sectoren waarin geen classificatieverandering heeft plaatsgevonden, geldt dat afwijkingen van het totaal te wijten zijn aan de afronding van gepresenteerde aantallen. 
Tabel 14

Belangrijkste opleidingsniveaus van de werkenden per bedrifssector, Limburg, gemiddelde 1997-1998

Bedrijfssector $\quad \% \quad$ trend 1993-1998

Landbouw en visserij

MMBO

HAVONWOIMBO

Voeding

VMBO

HAVOMNO/MBO

28

52

Chemie

VMBO

HAVONWO/MBO

19

55

Metaal en elektrotechniek

Basisonderwijs
VMBO
HAVO MWO/MBO
HBO

Overige industrie

Basisonderwijs

VMBO

HAVONWO/MBO

$\mathrm{HBO}$

10

29

45

12

36

49

dalend

constant

constant

sterk stijgend

sterk stijgend

stijgend

sterk stijgend

dalend

constant

constant

stijgend

dalend

dalend

sterk stijgend

Energie

HAVONWO/MBO

47

dalend

Bouw en onroerend goed

Basisonderwijs

$\checkmark M B O$

HAVOMWO/MBO

sterk dalend

constant

stijgend

Handel en reparatie

Basisonderwils
VMBO
HAVONWO/MBO
HBO

stijgend

dalend

constant

constant

Transport en communicatie

Basisonderwijs
VMBO
HAVOMWO/MBO
HBO

sterk dalend

dalend

stijgend

stijgend 
Tabel 1.4 (vervolg)

Belangrijkste opleidingsniveaus van de werkenden per bedrijfssector. Limburg, gemiddelde 1997-1998

Bedrijissector $\quad \%{ }^{\circ} \quad$ trend 1993-1998

Bank- en verzekeringswezen
HAVONWO/MBO
60
constant
HBO
19
dalend

Horeca en zakelijke dienstveriening

\author{
Basisonderwijs \\ VMBO \\ HAVOMWOIMBO \\ HBO \\ WO
}

$\begin{aligned} 8 & \text { sterk dalend } \\ 20 & \text { stiggend } \\ 44 & \text { dalend } \\ 19 & \text { constant } \\ 8 & \text { dalend }\end{aligned}$

Kwartaire diensten

VMBO
HAVONWOMBO
HBO
WO

sterk dalend

constant

constant

stijgend

Overheid en onderwijs

$\begin{array}{lll}\text { VMBO } & 12 & \text { constant } \\ \text { HAVONWOIMBO } & 35 & \text { constant } \\ \text { HBO } & 36 & \text { dalend } \\ \text { WO } & 15 & \text { stijgend }\end{array}$

Totaal

Basisonderwijs

VMBO

HAVO/WWO/MBO

$\mathrm{HBO}$

WO

$\begin{aligned} 8 & \text { constant } \\ 22 & \text { dalend } \\ 46 & \text { constant } \\ 16 & \text { constant } \\ 6 & \text { stijgend }\end{aligned}$

Bron: CBSIROA 
Tabel $1.5 a$

Percentage jongeren (15-29 jaar) per bedrijfssector. Limburg, gemiddelde 1997-1998

\begin{tabular}{|c|c|c|c|c|}
\hline Bedrififssector & $\%$ & typering & $\begin{array}{l}\text { Limburg t.o.v. } \\
\text { Nederland }\end{array}$ & $\begin{array}{l}\text { trend } \\
1993-1998\end{array}$ \\
\hline $\begin{array}{l}\text { Landbouw en visserij } \\
\text { Voeding } \\
\text { Chemie } \\
\text { Metaal en elektrotechniek } \\
\text { Overige industrie } \\
\text { Energie } \\
\text { Bouw en onroerend goed } \\
\text { Handel en reparatie } \\
\text { Transport en communicatie } \\
\text { Bank- en verzekeringswezen } \\
\text { Horeca en zakelije dienstverlening } \\
\text { Kwartaire diensten } \\
\text { Overheid en onderwijs }\end{array}$ & $\begin{array}{r}22 \\
32 \\
19 \\
29 \\
18 \\
- \\
22 \\
36 \\
22 \\
27 \\
32 \\
24 \\
13\end{array}$ & $\begin{array}{l}\text { laag } \\
\text { hoog } \\
\text { laag } \\
\text { gemiddeld } \\
\text { laag } \\
\text { laag } \\
\text { erg hoog } \\
\text { laag } \\
\text { gemiddeld } \\
\text { hoog } \\
\text { gemiddeld } \\
\text { erg laag }\end{array}$ & $\begin{array}{l}\text { laag } \\
\text { gemiddeld } \\
\text { laag } \\
\text { hoog } \\
\text { laag } \\
\text { - } \\
\text { laag } \\
\text { gemiddeld } \\
\text { laag } \\
\text { gemiddeld } \\
\text { gemiddeld } \\
\text { gemiddeld } \\
\text { laag }\end{array}$ & $\begin{array}{l}\text { sterk dalend } \\
\text { sterk dalend } \\
\text { dalend } \\
\text { sterk datend } \\
\text { dalend } \\
\text { onbekend } \\
\text { constant } \\
\text { dalend } \\
\text { dalend } \\
\text { sterk stijgend } \\
\text { constant } \\
\text { stijgend } \\
\text { stijgend }\end{array}$ \\
\hline Totaal & 25 & - & * & constant \\
\hline
\end{tabular}

Bron: CBS/ROA 
Tabel $1.5 b$

Percentage ouderen (50-64 jaar) per bedrijfssector, Limburg. gemiddelde 1997-1998

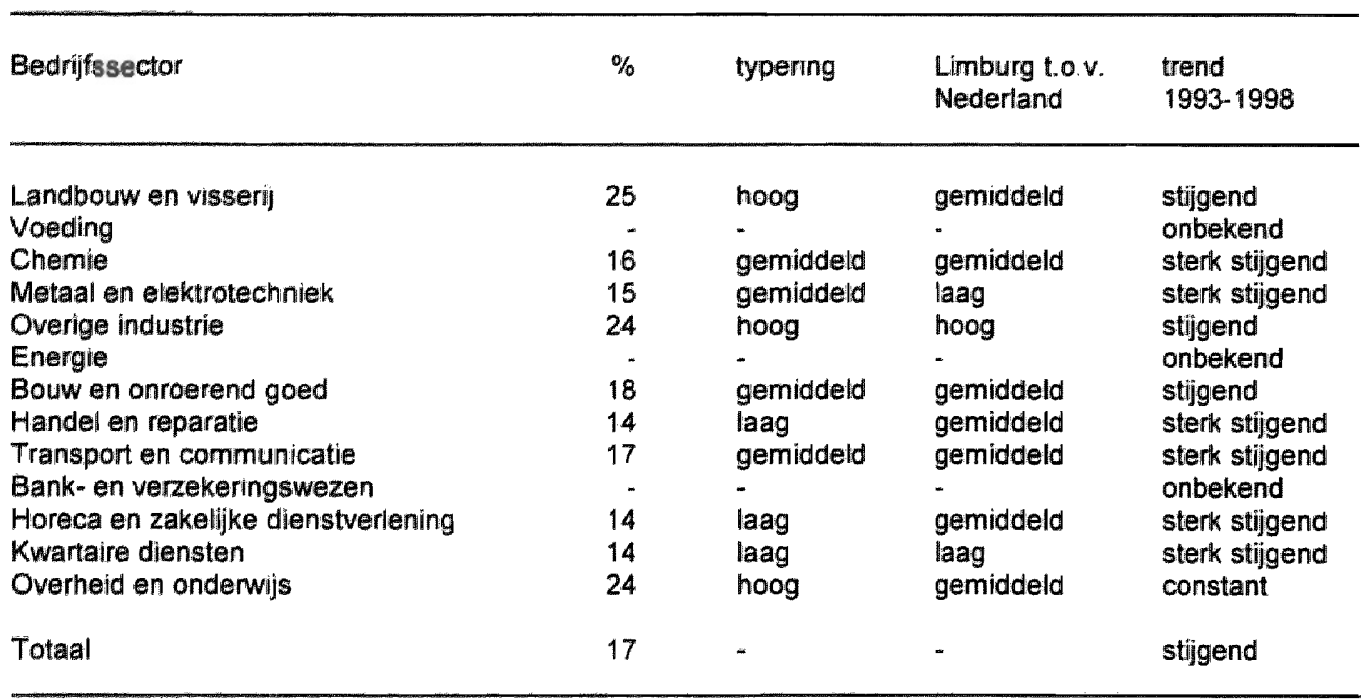

Bron: CBS/ROA 
Tabel 1.6

Percentage vrouwen per bedrijfssector, Limburg, gemiddelde 1997-1998

\begin{tabular}{|c|c|c|c|c|}
\hline Bedriffssector & $\%$ & typering & $\begin{array}{l}\text { Limburg to.v. } \\
\text { Nederland }\end{array}$ & $\begin{array}{l}\text { trend } \\
1993-1998\end{array}$ \\
\hline $\begin{array}{l}\text { Landbouw en visserij } \\
\text { Voeding } \\
\text { Chemie } \\
\text { Metaal en elektrotechniek } \\
\text { Overige industrie } \\
\text { Energie } \\
\text { Bouw en onroerend goed } \\
\text { Handel en reparatie } \\
\text { Transport en communicatie } \\
\text { Bank- en verzekeringswezen } \\
\text { Horeca en zakelijke dienstverlening } \\
\text { Kwartaire diensten } \\
\text { Overheid en onderwijs }\end{array}$ & $\begin{array}{r}34 \\
32 \\
13 \\
21 \\
12 \\
45 \\
20 \\
50 \\
46 \\
75 \\
37\end{array}$ & $\begin{array}{l}\text { gemiddeld } \\
\text { gemiddeld } \\
- \\
\text { laag } \\
\text { gemiddeld } \\
\text { laag } \\
\text { hoog } \\
\text { laag } \\
\text { hoog } \\
\text { hoog } \\
\text { erg hoog } \\
\text { gemiddeld }\end{array}$ & $\begin{array}{l}\text { erg hoog } \\
\text { gemiddeld } \\
\text { gemiddeld } \\
\text { laag } \\
\text { hoog } \\
\text { hoog } \\
\text { laag } \\
\text { hoog } \\
\text { gemiddeld } \\
\text { gemiddeld } \\
\text { gemiddeld }\end{array}$ & $\begin{array}{l}\text { constant } \\
\text { stijgend } \\
\text { onbekend } \\
\text { constant } \\
\text { stijgend } \\
\text { onbekend } \\
\text { sterk stijgend } \\
\text { constant } \\
\text { constant } \\
\text { stijgend } \\
\text { stijgend } \\
\text { constant } \\
\text { stijgend }\end{array}$ \\
\hline Totaal & 37 & - & - & constant \\
\hline
\end{tabular}

Bron: CBS/ROA 
Tabel 1.7

Percentage flexibel werk per bedrifíssector, Limburg, gemiddelde 1997-1998

\begin{tabular}{|c|c|c|c|c|}
\hline Bedriffssector & $\%$ & typering & $\begin{array}{l}\text { Limburg to.v } \\
\text { Nederland }\end{array}$ & $\begin{array}{l}\text { trend } \\
1993-1998\end{array}$ \\
\hline $\begin{array}{l}\text { Landbouw en visserij } \\
\text { Voeding } \\
\text { Chemie } \\
\text { Metaal en elektrotechniek } \\
\text { Overige industrie } \\
\text { Energie } \\
\text { Bouw en onroerend goed } \\
\text { Handel en reparatie } \\
\text { Transport en communicatie } \\
\text { Bank- en verzekerngswezen } \\
\text { Horeca en zakelijke dienstverlening } \\
\text { Kwartaire diensten } \\
\text { Overheid en onderwijs }\end{array}$ & $\begin{array}{r}16 \\
- \\
8 \\
8 \\
- \\
8 \\
8 \\
11 \\
- \\
11 \\
8 \\
5\end{array}$ & $\begin{array}{l}\text { hoog } \\
\text { - } \\
\text { gemiddeld } \\
\text { gemiddeld } \\
\text { - } \\
\text { - } \\
\text { gemiddeld } \\
\text { gemiddeld } \\
\text { gemiddeld } \\
\text { gemiddeld } \\
\text { erg laag }\end{array}$ & $\begin{array}{l}\text { erg hoog } \\
- \\
\text { gemiddeld } \\
\text { hoog } \\
- \\
\text { - } \\
\text { laag } \\
\text { hoog } \\
\text { - } \\
\text { gemiddeld } \\
\text { laag } \\
\text { laag }\end{array}$ & $\begin{array}{l}\text { sterk stijgend } \\
\text { onbekend } \\
\text { onbekend } \\
\text { sterk dalend } \\
\text { dalend } \\
\text { onbekend } \\
\text { onbekend } \\
\text { stijgend } \\
\text { constant } \\
\text { onbekend } \\
\text { stijgend } \\
\text { stijgend } \\
\text { sterk stijgend }\end{array}$ \\
\hline Totaal & 8 & - & - & constant \\
\hline
\end{tabular}

Bron: CBS/ROA 
Tabel 1.8

Percentage deeltijdwerk per bedrijtssector, Limburg, gemiddelde 1997-1998

\begin{tabular}{|c|c|c|c|c|}
\hline Bedrijfssector & $\%$ & typering & $\begin{array}{l}\text { Limburg t o.v. } \\
\text { Nederland }\end{array}$ & $\begin{array}{l}\text { trend } \\
1993-1998\end{array}$ \\
\hline $\begin{array}{l}\text { Landbouw en visserij } \\
\text { Voeding } \\
\text { Chemie } \\
\text { Metaal en elektrotechniek } \\
\text { Overige industrie } \\
\text { Energie } \\
\text { Bouw en onroerend goed } \\
\text { Handel en reparatie } \\
\text { Transport en communicatie } \\
\text { Bank- en verzekeringswezen } \\
\text { Horeca en zakelijke dienstverlening } \\
\text { Kwartaire diensten } \\
\text { Overheid en onderwijs }\end{array}$ & $\begin{array}{r}34 \\
- \\
- \\
8 \\
14 \\
- \\
9 \\
33 \\
17 \\
23 \\
37 \\
57 \\
22\end{array}$ & $\begin{array}{l}\text { hoog } \\
\text { - } \\
\text { laag } \\
\text { gemiddeld } \\
\text { - } \\
\text { laag } \\
\text { hoog } \\
\text { gemiddeld } \\
\text { gemiddeld } \\
\text { hoog } \\
\text { erg hoog } \\
\text { gemiddeld }\end{array}$ & $\begin{array}{l}\text { erg hoog } \\
\text { laag } \\
\text { laag } \\
\text { gemiddeld } \\
\text { hoog } \\
\text { gemiddeld } \\
\text { hoog } \\
\text { hoog } \\
\text { gemiddeld } \\
\text { laag }\end{array}$ & $\begin{array}{l}\text { stijgend } \\
\text { onbekend } \\
\text { onbekend } \\
\text { sterk stijgend } \\
\text { sterk stijgend } \\
\text { onbekend } \\
\text { sterk stijgend } \\
\text { stijgend } \\
\text { dalend } \\
\text { sterk stijgend } \\
\text { sterk stijgend } \\
\text { constant } \\
\text { constant }\end{array}$ \\
\hline Totaal & 27 & - & - & stijgend \\
\hline
\end{tabular}

Bron: CBS/ROA 
Percentage zelfstandigen per bedriffssector. Limburg, gemiddeide 1997-1998

\begin{tabular}{|c|c|c|c|c|}
\hline Bedrijfssector & $\%$ & typering & $\begin{array}{l}\text { Limburg to.v. } \\
\text { Nederland }\end{array}$ & $\begin{array}{l}\text { trend } \\
1993-1998\end{array}$ \\
\hline $\begin{array}{l}\text { Landbouw en visserij } \\
\text { Voeding } \\
\text { Chemie } \\
\text { Metaal en elektrotechniek } \\
\text { Overige industre } \\
\text { Energie } \\
\text { Bouw en onroerend goed } \\
\text { Handel en reparatie } \\
\text { Transport en communicatie } \\
\text { Bank- en verzekeringswezen } \\
\text { Horeca en zakelijke dienstverlening } \\
\text { Kwartaire diensten } \\
\text { Overheid en onderwijs }\end{array}$ & $\begin{array}{r}56 \\
- \\
- \\
- \\
12 \\
18 \\
- \\
21 \\
6 \\
-\end{array}$ & $\begin{array}{l}\text { erg hoog } \\
- \\
- \\
- \\
\text { - } \\
\text { homiddeld } \\
- \\
\text { hoog } \\
\text { gemiddeld } \\
-\end{array}$ & $\begin{array}{l}\text { gemiddeld } \\
- \\
- \\
- \\
- \\
\text { laag } \\
\text { hoog } \\
- \\
\text { hoog } \\
\text { laag } \\
-\end{array}$ & $\begin{array}{l}\text { constant } \\
\text { onbekend } \\
\text { onbekend } \\
\text { onbekend } \\
\text { onbekend } \\
\text { onbekend } \\
\text { dalend } \\
\text { constant } \\
\text { onbekend } \\
\text { onbekend } \\
\text { sterk dalend } \\
\text { sterk stijgend } \\
\text { onbekend }\end{array}$ \\
\hline Totaal & 11 & - & - & stijgend \\
\hline
\end{tabular}

Bron: CBS/ROA 
Tabel 1.10

Aantal werkenden per beroepsgroep. Limburg, gemiddelle $1997-1998$

Beroepsgroep

Leraar basisonderwijs

Docenten talen en expressie

Agrarische arbeiders

Agrarische bedrijfshoofiden

Productiemedewerkers

Concièrges

Bouwrakkers

Aannemers en installateurs

Weg-en waterbouwkundige vakkrachten

Metaalarbeiders

Bankwerkers en lassers

Assembleurs

Monteurs

Elektromonteurs

Mechanisch operators

Procesoperators

Confectie-arbeiders

Laders en lossers

Chauffeurs

Verplegenden en doktersassistenten

Therapeuten en verpleegkundigen

Artsen

Apothekersassistenten en medisch laboranten

Kantoorhulpen, inpakkers en colporteurs

Productieplanners

Receptionisten en administratieve employés

Boekhouders en secretaresses

Assistent accountants

Accountants

Commercieel employés

Commercieel medewerkers

Jurıdisch en fiscaal medewerkers

Juristen

Leidinggevenden

Managers

Programmeurs

Systeemanalisten

Activiteitenbegeleiders en medewerkers arbeidsbemiddeling

Medewerkers sociaal-cultureel werk en personeel en arbeid

Vakkenvullers

Interieurverzorgers

Verkopers

Winkeliers

Hulpkrachten horeca en verzorging

Ziekenverzorgenden

Verzorgend personeel

Bedrijfshoofden horeca

Aspirant politieagenten, soldaten en beveiligingshulpkrachten

Politieagenten, onderofficieren en bevelligingsemployés

Totaal

aantal

Limburg t.o.v.

Nederland

trend

1993-1998

gemiddeld

gemideld

gemiddeld

gemiddeld

hoog

gemiddeld

hoog

gemiddeld

hoog

hoog

hoog

erg hoog

hoog

hoog

gemiddeid

erg hoog

erg hoog

laag

hoog

gemiddeld

gemiddeld

laag

hoog

gemiddeld

laag

gemiddeld

gemiddeld

laag

gemiddeld

laag

laag

hoog

erg laag

gemidideld

gemiddeld

laag

erg laag

laag

4.000

6.000

2.500

12.500

19000

10.000

11.500

5.000

14.500

3.000

2.500

3.500

463.500 stijgend

sterk stijgend

constant

constant

dalend

constant

constant

dalend

constant

constant

stijgend

sterk stijgend

constant

constant

dalend

constant

dalend

stijgend

stijgend

constant

constant

sterk stijgend

constant

sterk stijgend

stijgend

constant

stijgend

stijgend

sterk stijgend

sterk stiigend

stijgend

stijgend

constant

constant

sterk sttjgend

sterk stijgend

sterk stijgend

sterk stijgend

constant

stijgend

constant

stijgend

dalend

constant

stijgend

dalend

dalend

constant

constant

constant 
Tabel 1.11

Aantal werkenden per beroepssegment, Zuid-Limburg, gemiddelde 1997-1998

Beroepssegment
Elementaire beroepen

Lagere niet-specialistische beroepen

Lagere docenten sportvakken

Lagere agrarische beroepen

Lagere wiskundige, natuurwetenschappelijke beroepen

Lagere technische beroepen

Lagere transportberoepen

Lagere (para)medische beroepen

Lagere administratieve, commerciële beroepen e.d.

Lagere beveiligingsberoepen

Lagere verzorgende beroepen

Middelbare docenten transport- en sportvakiken

Middelbare agrarische beroepen

Middelbare wiskundige, natuurwetenschappelijke beroepen

Middelbare technische beroepen

Middlelbare transportberoepen e.d.

Middelbare (para)medische beroepen

Middelbare administratieve, commerciële beroepen e.d.

Middelbare juridische, bestuurlijke beveiligingsberoepen

Middelbare taalkundige, culturele beroepen

Middelbare beroepen m.b.t. gedrag en maatschappij

Middelbare verzorgende beroepen e.d.

Hogere pedagogische beroepen

Hogere landbouwkundige beroepen

Hogere wiskundige, natuurwetenschappelijke beroepen

Hogere technische beroepen

Hogere transportberoepen

Hogere (para)medische beroepen

Hogere administratieve, commerciële, economische beroepen

Hogere juridische, bestuurlijke, beveiligingsberoepen

Hogere taalkundige, culturele beroepen

Hogere beroepen m.b.t. gedrag en maatschappij e.d.

Hogere verzorgende beroepen

Managers (HBO werk- en denkniveau)

Wetenschappelijke pedagogische beroepen

Wetenschappelijke landbouwkundige beroepen

Wetensch. wiskundige, natuurwetenschappelijke beroepen

Wetenschappelijke technische beroepen

Wetenschappelijke (para)medische beroepen e.d

Wetenschappelijke economische, admınistratieve beroepen e.d.

Wetenschappelijke jurıdische, bestuurlijke beroepen

Wetenschappelijke beroepen m.b.t gedrag en maatschappı

Managers (wetenschappelijk werk- en denkniveau)

Totaal aantal

19.000

Zuid-Limburg to. .

Limburg totaal

gemiddeld

-

erg laag

2.500

gemiddeld

23.500

10000

gemiddeld

22.000

hoog

7.500 hoog

$32.500 \quad$ hoog

$10.000 \quad$ gemiddeld

35.000 gemiddeld

4.500 hoog$$
\text { - }
$$

2.500

9.000

8.500

gemiddeld

gemiddeld

gemiddeld

$3000 \quad-5$

5.000

15.500

gemiddeld

gemiddeld

4.000

gemiddeld

-

4.000 hoog

- -

$2.500 \quad$ hoog

3.000 hoog

2.500 gemiddeld

-

$4000 \quad$ gemiddeld

Bron: CBS/ROA

Toelichting:

Het verschil tussen de subregionale optelling in de tabellen 1.11 en 1.12 en het totaal voor Limburg in tabel 2.10 houdt verband met de afronding van gepresenteerde aantallen. 
Tabel 1.12

Aantal werkenden per beroepssegment, Noord-en Midden-Limburg, gemiddelde 1997-1998

Beroepssegment

aantal

Noord-en Midden-

Limburg t.o.w.

Limburg totaa

Elementaire beroepen

Lagere niet-specialistische beroepen

Lagere docenten sportvakken

Lagere agrarische beroepen

Lagere wiskundige, natuurwetenschappelijke beroepen

Lagere technische beroepen

Lagere transportberoepen

Lagere (para)medische beroepen

Lagere administratieve, commerciële beroepen e.d.

Lagere beveiligingsberoepen

Lagere verzorgende beroepen

Middelbare docenten transport- en sportvakken

Middelbare agrarische beroepen

Middelbare wiskundige, natuurwetenschappelijke beroepen

Middelbare technische beroepen

Middelbare transportberoepen e.d.

Middelbare (para)medische beroepen

Middelbare administratieve, commerciële beroepen e.d.

Middelbare juridische, bestuurlijke beveiligingsberoepen

Middelbare taalkundige, culturele beroepen

Middelbare beroepen m.b.t. gedrag en maatschappij

Middelbare verzorgende beroepen e.d.

Hogere pedagogische beroepen

Hogere landbouwkundige beroepen

Hogere wiskundige, natuurwetenschappelijke beroepen

Hogere technische beroepen

Hogere transportberoepen

Hogere (para)medische beroepen

Hogere administratieve, commerciêle, economische beroepen

Hogere juridische, bestuurlijke, beveiligingsberoepen

Hogere taalkundige, culturele beroepen

Hogere beroepen m.b.t. gedrag en maatschappij e.d.

Hogere verzorgende beroepen

Managers (HBO werk- en denkniveau)

Wetenschappelijke pedagogische beroepen

Wetenschappelijke landbouwkundige beroepen

Wetensch. wiskundige, natuurwetenschappelijke beroepen

Wetenschappelijke technische beroepen

Wetenschappelijke (para)medische beroepen e.d.

Wetenschappelijke economische, administratieve beroepen e.d

Wetenschappelijke juridische. bestuurlijke beroepen

Wetenschappelijke beroepen $m \cdot b t$. gedrag en maatschappi

Managers (wetenschappelijk werk-en denkniveau)
15.500

gemiddeld

erg hoog

5.000

20.000

9.500

15.000

$5.500^{\circ}$

7.000

26.000

7.000

28.500

8.000
7.000

3.000

3.500

11500

gemiddeld

gemiddeld

laag

laag

erg hoog

laag

gemiddeld

gemiddeld

gemiddeld

gemiddeld

-

gemiddeld

-

gemiddeld

gemiddeld

-

gemiddeld

-

-

$-$

$-$

-

-

3.000

gemiddeld

Totaal

201.500

Bron: CBS/ROA

Toelichting:

Het verschil tussen de subregionale optelling in de tabellen 1.11 en 112 en het totaal voor Limburg in tabel 2.10 houdt verband met de afronding van gepresenteerde aantallen. 


\section{Elementaire beroepen}

Basisonderwijs

VMBO

HAVONWO/MBO

Lagere agrarische beroepen

VMBO

HAVOMWO/MBO

Lagere technische beroepen

Basisonderwijs

VMBO

HAVONWO/MBO

Lagere transportberoepen

Basisonderwijs

VMBO

HAVONWO/MBO
Basisonderwijs

VMBO

HAVONWO/MBO

Lagere verzorgende beroepen

VMBO

HAVONWO/MBO

Middelbare agrarische beroepen

VMBO

HAVONWO/MBO constant

constant

stijgend

Middelbare technische beroepen

Basisonderwijs

VMBO

HAVONWOMMOO

Middelbare (para)medische beroepen

HAVONWO/MBO

Middelbare administratieve, commerciële beroepen e.d.

\section{VMBO \\ HAVONWO/MBO \\ $\mathrm{HBO}$}

Middelbare juridische, bestuurlijke beveiligingsberoepen 
Tabel 1.13 (vervolg)

Belangrijkste opleidingsniveaus van de werkenden per beroepssegment, Limburg, gemiddelde 1997-1998

Beroepssegment

$\%$

trend $1993-1998$

Middelbare beroepen m.b.t. gedrag en maatschappij

HAVONWOMBO

constant

Middelbare verzorgende beroepen e.d.

HAVOMMOIMBO

81

constant

Hogere pedagogische beroepen

$\mathrm{HBO}$

86

constant

Hogere technische beroepen

HBO

62

stijgend

Hogere (para)medische beroepen

$\mathrm{HBO}$

77

constant

Hogere administratieve, commerciële beroepen e.d.

HAVONWOIMBO

dalend

$\mathrm{HBO}$

constant

constant

Hogere beroepen m.b.t. gedrag en maatschappij

HBO

constant

Wetenschappelijke pedagogische beroepen

WO

constant

Wetenschappelijke (para)medische beroepen e.d.

WO

constant

Wetenschappelijke economische, adm. beroepen e.d.

Wo

60

stijgend

Totaal

$\begin{array}{lrl}\text { Basisonderwijs } & 8 & \text { constant } \\ \text { VMBO } & 22 & \text { constant } \\ \text { HAVONWO/MBO } & 46 & \text { constant } \\ \text { HBO } & 16 & \text { stijgend } \\ \text { WO } & 6 & \text { constant }\end{array}$

Bron: CBS/ROA 
Tabel 1.14a

Percentage jongeren (15-29 jaar) per beroepssegment, Limburg, gemiddelde 1997-1998

\begin{tabular}{|c|c|c|c|c|}
\hline Beroepssegment & $\%$ & typering & $\begin{array}{l}\text { Limburg to.v. } \\
\text { Nederland }\end{array}$ & $\begin{array}{l}\text { trend } \\
1993-1998\end{array}$ \\
\hline $\begin{array}{l}\text { Elementarre beroepen } \\
\text { Lagere technische beroepen } \\
\text { Lagere transportberoepen } \\
\text { Lagere adm., commerciele beroepen e.d. } \\
\text { Lagere verzorgende beroepen } \\
\text { Middelbare technische beroepen } \\
\text { Middelbare (para)medische beroepen } \\
\text { Middelbare adm., commerciele beroepen e.d. } \\
\text { Middelbare verzorgende beroepen e.d. } \\
\text { Hogere adm., commerciele beroepen e.d. }\end{array}$ & $\begin{array}{l}32 \\
26 \\
21 \\
34 \\
35 \\
23 \\
34 \\
25 \\
37 \\
19\end{array}$ & $\begin{array}{l}\text { hoog } \\
\text { gemiddeld } \\
\text { gemiddeld } \\
\text { hoog } \\
\text { hoog } \\
\text { gemiddeld } \\
\text { hoog } \\
\text { gemiddeld } \\
\text { hoog } \\
\text { gemiddeld }\end{array}$ & $\begin{array}{l}\text { gemiddeld } \\
\text { laag } \\
\text { laag } \\
\text { laag } \\
\text { laag } \\
\text { laag } \\
\text { gemiddeld } \\
\text { laag } \\
\text { gemiddeld } \\
\text { laag }\end{array}$ & $\begin{array}{l}\text { constant } \\
\text { constant } \\
\text { constant } \\
\text { constant } \\
\text { dalend } \\
\text { constant } \\
\text { dalend } \\
\text { constant } \\
\text { dalend }\end{array}$ \\
\hline Totaal & 25 & - &. & constant \\
\hline
\end{tabular}

Bron: CBSIROA 
Percentage ouderen (50-64 jaar) per beroepssegment, Limburg, gemiddelde 1997-1998

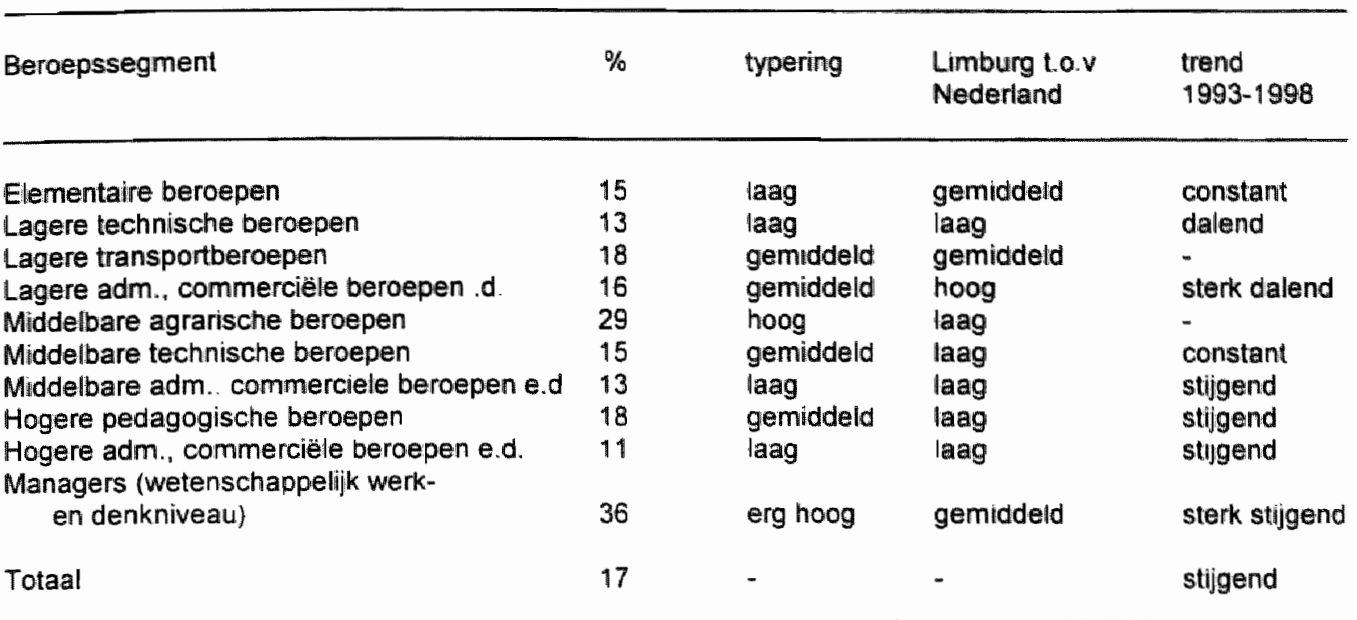


Percentage wrouwen per beroepssegment, Limburg. gemiddelde 1997-1998

\begin{tabular}{|c|c|c|c|c|}
\hline Beroepssegment & $\%$ & typering & $\begin{array}{l}\text { Limburg to.v. } \\
\text { Nederiand }\end{array}$ & $\begin{array}{l}\text { trend } \\
1993-1998\end{array}$ \\
\hline $\begin{array}{l}\text { Elementaire beroepen } \\
\text { Lagere agrarische beroepen } \\
\text { Lagere technische beroepen } \\
\text { Lagere adm., commerciele beroepen e.d. } \\
\text { Lagere verzorgende beroepen } \\
\text { Middelbare technische beroepen } \\
\text { Middelbare (para)medische beroepen } \\
\text { Middelbare adm., commerciële beroepen } \\
\text { Middelbare beroepen m.b.t. gedrag } \\
\text { en maatschappij } \\
\text { Middelbare verzorgende beroepen e.d. } \\
\text { Hogere pedagogische beroepen } \\
\text { Hogere (para)medische beroepen } \\
\text { Hogere administratieve, commerciële, } \\
\text { economische beroepen } \\
\text { Hogere beroepen m.b.t. gedrag } \\
\text { en maatschappij e.d. }\end{array}$ & $\begin{array}{r}50 \\
32 \\
12 \\
76 \\
74 \\
4 \\
87 \\
49 \\
\\
66 \\
75 \\
56 \\
73 \\
21 \\
\\
56\end{array}$ & $\begin{array}{l}\text { hoog } \\
\text { gemiddeld } \\
\text { laag } \\
\text { erg hoog } \\
\text { erg hoog } \\
\text { erg laag } \\
\text { erg hoog } \\
\text { hoog } \\
\text { hoog } \\
\text { erg hoog } \\
\text { hoog } \\
\text { erg hoog } \\
\text { gemiddeld } \\
\text { hoog }\end{array}$ & $\begin{array}{l}\text { hoog } \\
\text { hoog } \\
\text { gemiddeld } \\
\text { gemiddeld } \\
\text { gemiddeld } \\
\text { gemiddeld } \\
\text { gemiddeld } \\
\text { gemiddeld } \\
\text { gemiddeld } \\
\text { gemiddeld } \\
\text { gemiddeld } \\
\text { gemiddeld } \\
\text { laag } \\
\text { gemiddeld }\end{array}$ & $\begin{array}{l}\text { stijgend } \\
\text { dalend } \\
\text { sterk dalend } \\
\text { sterk dalend } \\
\text { constant } \\
\text { sterk dalend } \\
\text { sterk dalend } \\
\text { sterk dalend } \\
\text { stijgend } \\
\text { constant } \\
\text { constant } \\
\text { stijgend }\end{array}$ \\
\hline
\end{tabular}

Bron: CBS/ROA 
Tabel 1.16

Percentage flexibel werk per beroepssegment, Limburg, gemiddelde 1997-1998

Beroepssegment

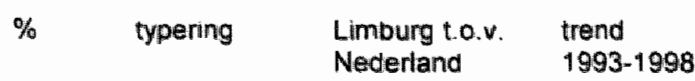

$\begin{array}{lllll}\text { Elementaire beroepen } & 23 & \text { erg hoog } & \text { laag } & \text { stijgend } \\ \text { Lagere technische beroepen } & 10 & \text { gemiddeld } & \text { erg laag } & \text { stijgend } \\ \text { Lagere transportberoepen } & 13 & \text { erg hoog } & \text { laag } & \text { constant } \\ \text { Lagere adm., commerciele beroepen e.d. } & 14 & \text { erg hoog } & \text { laag } & \text { constant } \\ \text { Lagere verzorgende beroepen } & 19 & \text { erg laag } & \text { erg laag } & \text { dalend } \\ \text { Middelbare technische beroepen } & 5 & \text { gemiddeld } & \text { erg laag } & \text { constant } \\ \text { Middelbare adm., commerciěle beroepen } & 4 & \text { gemiddeld } & \text { erg laag } & \text { sterk dalend } \\ \text { Totaal } & 8 & & & \end{array}$

Bron. CBS/ROA 
Tabel 1.17

Percentage deeltijolwerk per beroepssegment, Limburg, gemiddelde 1997-1998

\begin{tabular}{|c|c|c|c|c|}
\hline Beroepssegment & $\%$ & typering & $\begin{array}{l}\text { Limburg t.o.v. } \\
\text { Nederland }\end{array}$ & $\begin{array}{l}\text { trend } \\
1993-1998\end{array}$ \\
\hline $\begin{array}{l}\text { Elementaire beroepen } \\
\text { Lagere technische beroepen } \\
\text { Lagere transportberoepen } \\
\text { Lagere adm., commerciële beroepen e.d. } \\
\text { Lagere verzorgende beroepen } \\
\text { Middelbare technische beroepen } \\
\text { Middelbare (para)medische beroepen } \\
\text { Middelbare adm., commerciele beroepen } \\
\text { Middelbare verzorgende beroepen e.d. } \\
\text { Hogere pedagogische beroepen } \\
\text { Hogere (para)medische beroepen } \\
\text { Hogere administratieve, commerciele. } \\
\text { economische beroepen e.d. }\end{array}$ & $\begin{array}{r}47 \\
9 \\
15 \\
57 \\
69 \\
5 \\
60 \\
25 \\
57 \\
27 \\
50\end{array}$ & $\begin{array}{l}\text { hoog } \\
\text { laag } \\
\text { gemiddeld } \\
\text { erg hoog } \\
\text { erg hoog } \\
\text { erg laag } \\
\text { erg hoog } \\
\text { gemiddeld } \\
\text { erg hoog } \\
\text { gemiddeld } \\
\text { gemiddeld } \\
\text { laag }\end{array}$ & $\begin{array}{l}\text { gemiddeld } \\
\text { laag } \\
\text { hoog } \\
\text { gemiddeld } \\
\text { gemiddeld } \\
\text { laag } \\
\text { gemiddeld } \\
\text { gemiddeld } \\
\text { gemiddeld } \\
\text { laag } \\
\text { gemiddeld } \\
\text { laag }\end{array}$ & $\begin{array}{l}\text { stijgend } \\
\text { constant } \\
- \\
\text { stijgend } \\
\text { dalend } \\
\text { constant } \\
\text { constant } \\
\text { constant } \\
\text { stijgend } \\
\text { constant } \\
\text { constant }\end{array}$ \\
\hline Totaal & 27 & - & - & stijgend \\
\hline
\end{tabular}

Bron: CBS/ROA 


\section{Tabel 1.18}

Percentage zelfstandigen per beroepssegment, Limburg, gemiddelde 1997-1998

\begin{tabular}{|c|c|c|c|c|}
\hline Beroepssegment & $\%$ & typering & $\begin{array}{l}\text { Limburg } \text { l.o.v. } \\
\text { Nederland }\end{array}$ & $\begin{array}{l}\text { trend } \\
1993-1998\end{array}$ \\
\hline Lagere technische beroepen & 6 & gemiddeld & erg laag & constant \\
\hline Lagere verzorgende beroepen & 19 & erg laag & erg laiag & constant \\
\hline Middelbare agrarische beroepen & 88 & erg noog & erg hoog & - \\
\hline Middelbare technische beroepen & 10 & gemiddeld & hoog & stijgend \\
\hline Middelbare adm., commerciële beroepen & 12 & hoog & erg hoog & sterk dalend \\
\hline Middelbare verzorgende beroepen e.d. & 17 & hoog & gemiddeld & dalend \\
\hline economische beroepen e.d. & 19 & gemiddeld & erg laag & dalend \\
\hline Totaal & 11 & - & - & clalend \\
\hline
\end{tabular}

Bron: CBS/ROA 
Aantal werkenden per opleidingstype, Lumburg, gemıddelde 1997-1998

Opleidingstype

aantal

39.000

Basisonderwijs

VMBO theorie

VMBO landbouw en natuurlijke omgeving

VMBO bouwtechniek

VMBO mechanische techniek

VMBO motorvoertuigentechniek

VMBO elektrotechniek

VMBO techniek overig

VMBO administratie. handel en textiel

VMBO verzorging

HAVOMWO

MBO landbouw en veeteelt

MBO bouw

$\mathrm{MBO}$ installatietechniek

MBO werktuigbouw en mechanische techniek

MBO motorvoertuigentechniek

MBO elektrotechniek

MBO procestechniek

$M B O$ vervoer

MBO techniek overig

$M B O$ verpleging

MBO sociaal-cultureel

$M B O$ verzorging

MBO uiterlijke verzorging

MBO horeca

MBO beweging en therapie

MBO administratie

MBO handel

MBO secretariaat

MBO bedrijfskunde

MBO automatisering

MBO geld, bank en belastingen

MBO openbare orde en veiligheid

HBO lerarenopleiding basisonderwijs

HBO laboratorium

HBO werktulgbouwkunde

HBO elektrotechniek

HBO informatica

$\mathrm{HBO}$ verpleegkunde

HBO (fysio)theraple

HBO accountancy en bedriffseconomie

HBO commerciele economie

$\mathrm{HBO}$ bedrijfskunde

HBO maatschappelijk werk en hulpverlening

HBO uitvoerende en beeldende kunsten

WO wiskunde en natuurwetenschappen

WO (dier)geneeskunde

WO econom(etr)ie

WO rechten en bestuurskunde

WO sociale wetenschappen
30.000

3.500

10.500

11.500

3.500

4.500

6.500

9.000

17000

22.500

7.500

9.000

2.500

12.000

6.500

13.000

4000

3.000

4.000

10.500

4.500

18.000

4.500

6.500

2.500

23.500

18.000

7.000

3.500

2.500

2.500

7.000

11.500

2500

3000

2500

3000

3.500

3.000

4.500

3.000

4.500

4.500

3.000

3.500

3.000

2.500

3.000

3.500
Limburg t.o.v. trend Nederland

1993-1998

\section{hoog}

gemiddeld

laag

hoog

hoog

hoog

hoog

zeer hoog

gemiddeld

hoog

gemiddeld

gemiddeld

laag

hoog

noog

hoog

hoog

zeer hoog

laag

zeer hoog

hoog

laag

hoog

gemiddeld

hoog

hoog

hoog

laag

laag

gemiddeld

gemiddeld

hoog

gemiddeld

gemiddeld

gemiddeld

hoog

laag

hoog

gerniddeld

gemiddeld

gemiddeld

laag

gemiddeld

laag

gemiddeld

laag

gemiddeld

laag

zeer laag

zeer laag constant

constant

sterk dalend

constant

dalend

dalend

constant

stijgend

daiend

dalend

stijgend

constant

dalend

constant

dalend

sterk stijgend

stijgend

constant

constant

sterk stijgend

stijgend

stijgend

constant

dalend

stijgend

sterk stijgend

stijgend

constant

constant

stijgend

sterk stijgend

constant

stijgend

stijgend

dalend

stijgend

stijgend

stijgend

constant

stijgend

stijgend

sterk stijgend

sterk stijgend

constant

stijgend

constant

sterk stijgend

sterk stijgend

stijgend

constant

Totaal

463.500

Bron: CBS/ROA 
aantal

23.500

17.000

Basisondenwijs

VMBO Theorie

VMBO Landbouw en natuurlijke omgeving

VMBO Techniek

VMBO Economie

VMBO Verzorging

VMBO Openbare orde en veiligheid

HAVONWO

MBO Landbouw en natuurlijke omgeving

MBO Techniek

MBO Dienstverlening en gezondheidszorg

MBO Economie

$\mathrm{MBO}$ Openbare orde en veiligheid

HBO Onderwijs en tolk en vertaler

HBO Landbouw

HBO Techniek

HBO Paramedisch

HBO Economie

HBO Sociaal-cultureel

HBO Kunst

HBO Openbare orde en veiligheid

WO Letteren en theologie

WO Landbouw en milieukunde

WO Techniek

WO Medisch

WO Economie

WO Sociaal-cultureel

wo Kunst
Zuid-Limburg t.o.v. Limburg totaal.

Totaal

21.500

6.000

8.000

13.000

2.500

34.000

26.500

33.000

4.500

12.000

9.500

4500

10.000

5500

$\begin{aligned}- & - \\ - & - \\ - & - \\ 4.000 & \text { hoog } \\ 3.000 & \text { erg hoog } \\ 5.500 & \text { hoog } \\ 3.500 & \text { hoog } \\ - & -\end{aligned}$

Bron: CBS/ROA 
Tabed 1.21

Aantal werkenden per opleidingssector. Noord-en Midden-Limburg, gemıddelde 1997-1998

Opleidingssector

aantal

Noord-en Midden-Limburg

t.o.v. Limburg totaal

Basisonderwijs

VMBO theorie

15.500

12.500

2.500

VMBO Landbouw en natuurlijke omgeving

21.000

VMBO Techniek

VMBO Economie

3.500

VMBO Verzorging

9.000

VMBO Openbare orde en veiligherd

HAVONWO

9.500

MBO Landbouw en natuurlijke omgeving

MBO Techniek

6.000

MBO Dienstverlening en gezondheidszorg

29.000

23.000

MBO Economie

MBO Openbare orde en veiligheid

26.500

$\mathrm{HBO}$ Onderwijs en tolk en vertaler

3.000

HBO Landbouw

10.000

HBO Techniek

$6.500^{\circ}$

HBO Paramedisch

3.500

HBO Economie

6.500

HBO Sociaal-cultureel

2.500

laag

gemiddeld

erg hoog

gemiddeld

laag

gemiddeld

HBO Kunst

HBO Openbare orde en veiligheid

WO Letteren en theologie

WO Landbouw en millieukunde

WO Techniek

WO Medisch

WO Economie

WO Sociaal-cultureel

WO Kunst

Totaal

laag

erg hoog

gemiddeld

gemiddeld

laag

gemiddeld

gemiddeld

gemiddeld

gemiddeld

laag

laag

Bron: CBS/ROA

201.500 
Tabel 1.22

Arbeidsmarktpositie potentiêle beroepsbevolking naar opleidingstype, Limburg, gemiddelde 1997-1998

Opleidingstype $\quad \%$ werkzaam $\%$ werkloos $\begin{gathered}\% \text { niet- } \\ \text { participerend }\end{gathered}$

\begin{tabular}{|c|c|c|c|c|}
\hline BASISONDERWIJS & 40 & 5 & 55 & 100.500 \\
\hline Basisonderwijs & 40 & 5 & 55 & 100.500 \\
\hline VMBO & 57 & 3 & 40 & 182.000 \\
\hline $\begin{array}{l}\text { VMBO Theorie } \\
\text { VMBO theorie }\end{array}$ & 56 & 6 & 38 & 49.500 \\
\hline $\begin{array}{l}\text { VMBO Landbouw en natuurlijke omgeving } \\
\text { VMBO tandbouw en natuurlijke omgeving }\end{array}$ & 74 & $\cdot$ & - & 5.000 \\
\hline $\begin{array}{l}\text { VMBO Techniek } \\
\text { VMBO bouwtechniek } \\
\text { VMBO mechanische techniek } \\
\text { VMBO motorvoertuigentechniek } \\
\text { VMBO elektrotechniek }\end{array}$ & $\begin{array}{l}81 \\
74 \\
85 \\
79\end{array}$ & $\begin{array}{l}- \\
- \\
-\end{array}$ & 20 & $\begin{array}{r}12.500 \\
15.000 \\
4.000 \\
6.000\end{array}$ \\
\hline $\begin{array}{l}\text { VMBO Economie } \\
\text { VMBO administratie, handel en textiel }\end{array}$ & 48 & - & 45 & 19000 \\
\hline $\begin{array}{l}\text { VMBO Verzorging } \\
\text { VMBO verzorging }\end{array}$ & 33 & - & 62 & 50.500 \\
\hline HAVONWO, MBO & 75 & 2 & 23 & 279.000 \\
\hline $\begin{array}{l}\text { HAVONWO } \\
\text { HAVONWO }\end{array}$ & 68 & - & 26 & 28.500 \\
\hline $\begin{array}{l}\text { MBO Landbouw en natuurlijke omgeving } \\
\text { MBO landbouw en veeteelt }\end{array}$ & 84 & - & - & 9.000 \\
\hline $\begin{array}{l}\text { MBO Techniek } \\
\text { MBO bouw } \\
\text { MBO werktuigbouw en mechanische techniek } \\
\text { MBO motorvoertuigentechniek } \\
\text { MBO elektrotechniek } \\
\text { MBO procestechniek } \\
\text { MBO vervoer }\end{array}$ & $\begin{array}{l}82 \\
84 \\
94 \\
87 \\
94 \\
81\end{array}$ & $\begin{array}{l}- \\
- \\
- \\
-\end{array}$ & $\begin{array}{l}- \\
- \\
- \\
-\end{array}$ & $\begin{array}{r}10.500 \\
14000 \\
7.000 \\
14500 \\
4500 \\
3500\end{array}$ \\
\hline $\begin{array}{l}\text { MBO Dienstverlening en gezondheidszorg } \\
\text { MBO verpleging } \\
\text { MBO sociaal-cultureel } \\
\text { MBO verzorging } \\
\text { MBO uiterlijke verzorging } \\
\text { MBO horeca } \\
\text { MBO beweging en therapie }\end{array}$ & $\begin{array}{l}69 \\
68 \\
60 \\
52 \\
70 \\
74\end{array}$ & $\begin{array}{l}- \\
- \\
-\end{array}$ & $\begin{array}{r}30 \\
35 \\
41 \\
- \\
-\end{array}$ & $\begin{array}{r}15.000 \\
6.000 \\
30.500 \\
8.500 \\
9.000 \\
3.500\end{array}$ \\
\hline $\begin{array}{l}\text { MBO Economie } \\
\text { MBO administratie } \\
\text { MBO handel } \\
\text { MBO secretariaat } \\
\text { MBO bedrijfskunde } \\
\text { MBO automatisering } \\
\text { MBO geld, bank en belastingen }\end{array}$ & $\begin{array}{l}81 \\
65 \\
71 \\
91 \\
88 \\
89\end{array}$ & $\begin{array}{l}- \\
- \\
-\end{array}$ & $\begin{array}{r}16 \\
31 \\
- \\
- \\
-\end{array}$ & $\begin{array}{r}28.500 \\
27.500 \\
9.500 \\
4.000 \\
3.000 \\
3.000\end{array}$ \\
\hline
\end{tabular}


Tabol 122 (vervolg)

Arbeidsmarktpositie potentiële beroepsbevolking naar opleidingstype. Limburg, gemiddelde 1997-1998

Opleidingstype

$\%$ werkzaam

$\%$ werkloos

$\%$ niet-

totaa! participerend

MBO Openbare orde en vestigheid

MBO openbare orde en veiligheid

83

80

72

$\mathrm{HBO}$ lerarenopleiding basisonderwijs.

HBO Techniek

HBO laboratorium

$\mathrm{HBO}$ werktuigbouwkunde

HBO informatica

HBO Paramedisch

$H B O$ verpleegkunde

$\mathrm{HBO}$ (fysio)therapie

HBO Economie

HBO accountancy en bedrijfseconomie

$\mathrm{HBO}$ commerciéle economie

HBO bedrijfskunde

HBO Sociaal-cultureel

HBO maatschappelijk werk en hulpverlening

HBO Kunst

$\mathrm{HBO}$ uitvoerende en beeldende kunsten

wo

WO Techniek

WO wiskunde en natuurwetenschappen

WO Medisch

WO (dier)geneeskunde

WO Economie

WO econom(etr)ie

WO rechten en bestuurskunde

WO Sociaal-cultureel

WO sociale wetenschappen

Totaal

Bron CBS/ROA
80

82

98

92

89

91

92

88

78

79

87

92

94

86

91

79

66

3
8500

2

$18 \quad 97.000$

$23 \quad 15.500$

3.500

4.000

3.000

4.000

3.500

4.500

3.500

5.000

5.500

3.500

30.500

4.000

3.500

3.000

3.000

4.500

95.500 
Tabel 1.23a

Percentage jongeren (15-29 jaar) per opleidingssector, Limburg, gemiddelde 1997-1998

\begin{tabular}{lclll}
\hline Opleidingssector & $\%$ & typering & $\begin{array}{l}\text { Limburg t.0.v. } \\
\text { Nederland }\end{array}$ & $\begin{array}{l}\text { trend } \\
1993-1998\end{array}$ \\
& & & & \\
Basisonderwijs & 20 & gemiddeld & gemiddeld & stijgend \\
VMBO theorie & 29 & gemiddeld & laag & dalend \\
VMBO techniek & 7 & erg laag & erg laag & constant \\
VMBO verzorging & 21 & gemiddeld & gemiddeld & dalend \\
HAVONMO & 33 & gemiddeld & laag & constant \\
MBO techniek & 11 & erg laag & erg laag & dalend \\
MBO dienstverlening en gezondheidszorg & 19 & laag & erg laag & constant \\
MBO economie & 23 & gemiddeld & laag & dialend \\
Totaal & & & &
\end{tabular}

Bron: CBS/ROA 
Tabel $1.23 b$

Percentage ouderen (50-64) per opleidingssector, Lumburg, gemiddelde 1997-1998

\begin{tabular}{|c|c|c|c|c|}
\hline Opleidingssector & $\%$ & typering & $\begin{array}{l}\text { Limburg to.v. } \\
\text { Nederland }\end{array}$ & $\begin{array}{l}\text { trend } \\
1993-1998\end{array}$ \\
\hline $\begin{array}{l}\text { Basisonderwjs } \\
\text { VMBO theorie } \\
\text { VMBO techniek } \\
\text { VMBO verzorging } \\
\text { MBO techniek } \\
\text { MBO dienstverlening en gezondheidszorg } \\
\text { MBO economie } \\
\text { HBO onderwijs en tolk en vertaler } \\
\text { HBO techniek }\end{array}$ & $\begin{array}{r}25 \\
21 \\
18 \\
21 \\
18 \\
8 \\
13 \\
26 \\
20\end{array}$ & $\begin{array}{l}\text { hoog } \\
\text { hoog } \\
\text { gemiddeld } \\
\text { hoog } \\
\text { gemiddeld } \\
\text { erg laag } \\
\text { laag } \\
\text { erg hoog } \\
\text { gemiddeld }\end{array}$ & $\begin{array}{l}\text { gemiddeld } \\
\text { hoog } \\
\text { hoog } \\
\text { gemiddeld } \\
\text { gemiddeld } \\
\text { laag } \\
\text { laag } \\
\text { gemiddeld } \\
\text { gemiddeld }\end{array}$ & $\begin{array}{l}\text { constant } \\
\text { stijgend } \\
\text { stijgend } \\
\text { stijgend } \\
\text { stijgend } \\
\text { stijgend } \\
\text { constant } \\
\text { sterk stijgend } \\
\text { sterk stijgend }\end{array}$ \\
\hline Totaal & 17 & - & - & stijgend \\
\hline
\end{tabular}

Bron: CBS/ROA 
Tabel 1.24

Percentage vrouwen per opleidingssector, Limburg. gemiddelde 1997-1998

\begin{tabular}{|c|c|c|c|c|}
\hline Opleidingssector & $\%$ & typering & $\begin{array}{l}\text { Limburg t.o.w. } \\
\text { Nederland }\end{array}$ & $\begin{array}{l}\text { trend } \\
1993-1998\end{array}$ \\
\hline Basisonderwijs & 30 & gemiddeld & gemiddeld & constant \\
\hline VMBO theorie & 47 & gemiddeld & gemiddeld & constant \\
\hline VMBO economie & 64 & hoog & gemiddeld & constant \\
\hline VMBO verzorging & 96 & erg hoog & gemiddeld & constant \\
\hline HAVONWO & 49 & gemiddeld & gemiddeld & constant \\
\hline MBO dienstverlenıng en gezondheidszorg & 71 & hoog & laag & constant \\
\hline MBO economie & 43 & gemiddeld & gemiddeld & constant \\
\hline $\mathrm{HBO}$ onderwils en tolk en vertaler & 68 & hoog & hoog & constant \\
\hline Totaal & 37 & - & - & constant \\
\hline
\end{tabular}

Bron: CBS/ROA 
Tabel 1.25

Percentage flexibel werk per opleidingssector, Limburg, gemiddelde 1997-1998

\begin{tabular}{|c|c|c|c|c|}
\hline Opleidingssector & $\%$ & typering & $\begin{array}{l}\text { Limbuig to.v. } \\
\text { Nederland }\end{array}$ & $\begin{array}{l}\text { trend } \\
1993-1998\end{array}$ \\
\hline Basisonderwij]s & 13 & hoog & gemiddeld & constant \\
\hline VMBO theorie & 17 & erg hoog & gemiddeld & constant \\
\hline VMBO verzorging & 20 & erg hoog & hoog & stijgend \\
\hline HAVONMO & 18. & erg hoog & laag & constant \\
\hline MBO dienstverlening en gezondheidszorg & 6 & gemiddeld & erg laag & constant \\
\hline Totaa: & 8 & - & - & constant \\
\hline
\end{tabular}

Bron: CBS/ROA 
Tabel 1.26

Percentage deeltijdwerk per opleidingssector, Limburg, gemiddelde 1997-1998

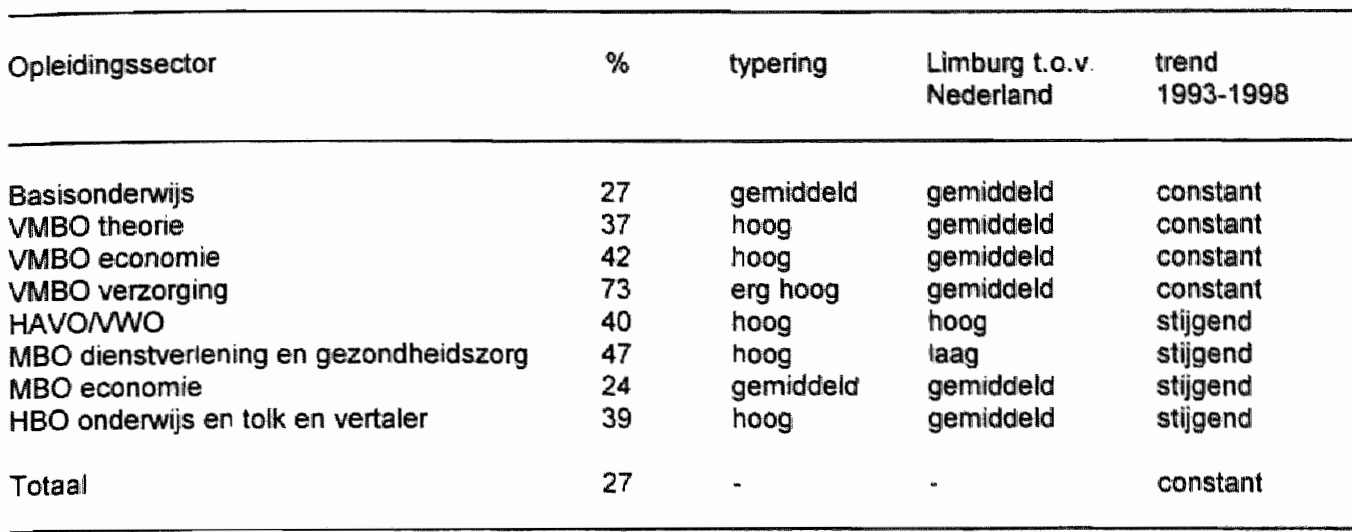

Bron: CBS/ROA 
Tabel 1.27

Percentage zelfstandigen per opleidingssector, Limburg, gemiddelde 1997-1998

\begin{tabular}{|c|c|c|c|c|}
\hline Opleidingssector & $\%$ & typering & $\begin{array}{l}\text { Limburg to.y. } \\
\text { Nederland }\end{array}$ & $\begin{array}{l}\text { trend } \\
1993-1998\end{array}$ \\
\hline $\begin{array}{l}\text { Basisonderwijs } \\
\text { VMBO theorie } \\
\text { VMBO verzorging } \\
\text { HAVOMWO } \\
\text { MBO landbouw en natuurlijke omgeving } \\
\text { MBO economie }\end{array}$ & $\begin{array}{r}9 \\
10 \\
15 \\
11 \\
47 \\
8\end{array}$ & $\begin{array}{l}\text { gemiddeld } \\
\text { gemiddeld } \\
\text { hoog } \\
\text { gemidideld } \\
\text { erg hoog } \\
\text { gemiddeld }\end{array}$ & $\begin{array}{l}\text { laag } \\
\text { hoog } \\
\text { hoog } \\
\text { gemiddeld } \\
\text { hoog } \\
\text { erg laag }\end{array}$ & $\begin{array}{l}\text { constant } \\
\text { constant } \\
\text { constant } \\
\text { constant } \\
\text { constant } \\
\text { constant }\end{array}$ \\
\hline Tolatal & 11 & - & - & constant \\
\hline
\end{tabular}

Bron. CBS/ROA 
Tabel 2.1

Openstaande vacatures per bedrijfssector, Limburg, april 1999

\begin{tabular}{|c|c|c|c|c|}
\hline Bedrifssector & aantal & $\begin{array}{l}\text { typering } \\
\text { vacature- } \\
\text { graad }\end{array}$ & $\begin{array}{l}\% \text { langdurig } \\
\text { openstaand }\end{array}$ & typering \\
\hline Landbouw en visserij & 575 & noog & 5 & zeer laag \\
\hline Voeding & 200 & gemiddeld & 18 & laag \\
\hline Chemie & 150 & laag & 19 & laag \\
\hline Metaal en elektrotechniek & 1.225 & gemiddeld & 39 & hoog \\
\hline Overige industrie & 375 & laag & 28 & gemiddeld \\
\hline Energie & 25 & zeer laag & - & - \\
\hline Bouw en onroerend goed & 1.100 & gemiddeld & 26 & gemiddeld \\
\hline Handel & 2.300 & gemiddeld & 22 & laag \\
\hline Transport en communicatie & 1.175 & hoog & 33 & gemiddeld \\
\hline $\begin{array}{l}\text { Bank-en verzekeringswezen } \\
\text { Horeca, reparatie en zakeliike }\end{array}$ & 400 & gemiddeld & 32 & gemiddeld \\
\hline dienstverlening & 4.625 & hoog & 32 & gemiddeld \\
\hline Kwartaire diensten & 1.525 & zeer hoog & 36 & hoog \\
\hline Overheid en onderwijs & 475 & laag & 49 & zeer hoog \\
\hline Totaal & 14.300 & & 34 & gemiddeld \\
\hline
\end{tabular}

Bron: Arbeidsvoorziening/CBS/ROA 
Tabel 2.2

Openstaande vacatures per beroepssegment, Limburg, april 1999

Beroepssegment aantal

typering

vacature-

$\%$ langdurig

openstaand

typering

graad

Elementaire beroepen

Lagere niet-specialistische beroepen

Lagere docenten sportvakken

Lagere agrarische beroepen

Lagere wiskundige, natuurwet. beroepen

Lagere technische beroepen

Lagere transportberoepen

Lagere (para)medische beroepen

Lagere administratieve, commerciële beroepen

Lagere beveiligıngsberoepen

Lagere verzorgende beroepen

Middelbare docenten transport-, sportvakken

Middelbare agrarische beroepen

Middelbare wiskundige. natuunwet. beroepen

Middebare technische beroepen

Middelbare transportberoepen e.c.

Middelbare (para)medische beroepen

Middelbare administratieve, commerciële beroepen e.d.

Middelbare juridische, bestuurlijke, bevelligingsberoepen

Middelbare taalkundige. culturele beroepen

Middelbare beroepen m.b.t. gedrag en maatschappij

Middelbare verzorgende beroepen e.d.

Hogere pedagogische beroepen

Hogere landbouwkundige beroepen

Hogere wiskundige, natuurwetenschappelijke beroepen

Hogere technische beroepen

Hogere transportberoepen

Hogere (para)medische beroepen

Hogere administratieve. commerciêle. ec beroepen

Hogere juridische, bestuurlijke, beveiligingsberoepen

Hogere taalkundige, culturele beroepen

Hogere beroepen m.b t gedirag en maatschappij

Hogere verzorgende beroepen

Managers (HBO werk- en denkniveau) e.d

$$
\begin{array}{r}
2.050 \\
- \\
- \\
200 \\
1.625 \\
875 \\
175 \\
2.025 \\
275 \\
1.725
\end{array}
$$

hoog

-

175

275

gemiddeld

gemiddeld

gemiddeld

*

gemiddeld

zeer hoog

$\begin{aligned} 100 & \text { laag } \\ - & - \\ 1275 & \text { laag } \\ 75 & \text { laag } \\ 225 & \\ & \\ 1.475 & \text { laag } \\ - & - \\ 25 & - \\ 200 & \text { gemiddeld } \\ 325 & \text { laag }\end{aligned}$

325 gemiddeld

$\begin{aligned} 75 & - \\ - & - \\ 100 & - \\ 250 & \text { gemiddeld }\end{aligned}$

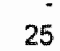

75

100

14.300 laag

-

zeer laag

gemiddeld

gemiddeld

zeer hoog

zeer laag

hoog

laag

hoog

-

gemiddeld

gemiddeld

hoog

37 gemiddeld

$-$

54 hoog

29 gemiddeld

25 laag

25 laag

- -

92 zeer hoog

gemuddeld

laag

-

gemiddeld

gemiddeld

31

Bron. Arbeldsvoorziening/CBS/ROA 
Tabel 2.3

Openstaande vacatures per opleidingssector, Limburg, apnl 1999

\begin{tabular}{|c|c|c|c|c|}
\hline Opleidingssector & aantal & $\begin{array}{l}\text { typering } \\
\text { vacature- } \\
\text { graad }\end{array}$ & $\begin{array}{l}\% \text { langdurig } \\
\text { openstaand }\end{array}$ & typering \\
\hline Basisonderwijs & 175 & zeer laag & - & - \\
\hline VMBO Theorie & 725 & gemiddeld & 24 & laag \\
\hline VMBO Landbouw en natuurlijke omgeving & 125 & hoog & 37 & gemiddeld \\
\hline VMBO Techniek & 2.500 & zeer hoog & 25 & laag \\
\hline VMBO Economie & 75 & laag & - & - \\
\hline VMBO Verzorging & 550 & hoog & 44 & hoog \\
\hline VMBO Openbare orde en veiligheid & 75 & & 54 & hoog \\
\hline VMBO Totaal & 4.475 & hoog & 30 & gemiddeld \\
\hline HAVOMWO & 300 & laag & 29 & gemiddeld \\
\hline MBO Landbouw en natuurlijke omgeving & 125 & laag & 39 & gemiddeld \\
\hline MBO Techniek & 1.150 & gemiddeld & 37 & gemiddeld \\
\hline MBO Dienstverlening en gezondheidszorg & 800 & laag & 33 & gemiddeld \\
\hline MBO Economie & 2.175 & hoog & 19 & zeer laag \\
\hline MBO Openbare orde en veiligheid & - &. & . & $-x$ intal \\
\hline MBO Totaal & 4.925 & gemiddeld & 27 & gemiddeld \\
\hline HBO Onderwijs en tolk en vertaler & 325 & gemiddeld & 39 & gemiddeld \\
\hline HBO Landbouw & 25 & - & - & - \\
\hline HBO Techniek & 375 & hoog & 54 & hoog \\
\hline HBO Paramedisch & 150 & gemiddeld & 39 & gemiddeld \\
\hline HBO Economie & 300 & gemiddeld & 41 & gemiddeld \\
\hline HBO Sociaal-cultureel & 100 & gemiddeld & 29 & gemiddeld \\
\hline HBO kunst & - & - & - & - \\
\hline HBO Openbare orde en veiligheid & . & - & - & - \\
\hline HBO Totaal & 1.625 & gemiddeld & 39 & gemiddeld \\
\hline Totaal & 14.300 & & 31 & \\
\hline
\end{tabular}

Bron Arbeidsvoorziening/CBS/ROA 
Tabel 2.4

Niet-werkende werkzoekenden per beroepssegment. Limburg. april 1999

Beroepssegment

aantal typenng $\quad \%$ langdurig
$\%$ beroeps-
zevolking

typering

Elementaire beroepen

Lagere niet-specialistische beroepen

Lagere docenten sportvakken

Lagere agrarische beroepen

Lagere wiskundige, natulunwet. beroepen

Lagere technische beroepen

Lagere transportberoepen

Lagere (para)medische beroepen

Lagere adm., commerciele beroepen e.d.

Lagere beveiligungsberoepen

Lagere verzorgende beroepen

Middelbare docenten transport-, sportvakken

Middelbare agrarische beroepen

Middelbare wiskundige, natuurwet. beroepen

Middelbare technische beroepen

Middelbare transportberoepen e.d.

Middelbare (para)medische beroepen

Middelbare adm., commerciéle beroepen e.d

Middelbare juridische, bestuurlijke, bev. beroepen

Middelbare taalkundige, culturele beroepen

Middelbare beroepen m.b.t. gedrag en maatsch

Middelbare verzorgende beroepen e.d.

Hogere pedagogische beroepen

Hogere landbouwkundige beroepen

Hogere wiskundige, natuurwet. beroepen

Hogere technische beroepen

Hogere transportberoepen

Hogere (para)medische beroepen

Hogere acm. commerciele, ec. beroepen

Hogere juridische, bestuurlijke. bev. beroepen

Hogere taalkundige, culturele beroepen

Hogere beroepen m.b.t gedrag en maatschappij

Hogere verzorgende beroepen

Managers (HBO werk - en denkniveau) e.d.

Wetenschappelijke pedagogische beroepen

Wetenschappelike landbouwkundige beroepen

Wetenschappelijke wisk. natuurwet. beroepen

Wetenschappelike technische beroepen

Wetenschappelijke (para)medische beroepen e.d

Wetenschappelijke ec. adm. beroepen e.d

Wetenschappelijke juridische, bestuurlijke beroepen

Wet. beroepen m.b.t. gedrag en maatschappi

Managers (wetenschappelijk werk-en denkniveau)

Totaal

Bron: Arbeidsvoorziening/ROA

\begin{tabular}{|c|c|c|c|}
\hline 10.900 & zeer hoog & 63 & hoog \\
\hline - & - & - & - \\
\hline- & - & - & - \\
\hline 225 & laag & 55 & gemiddeld \\
\hline- & - & - & - \\
\hline 2.725 & gemiddeld & 39 & zeer laag \\
\hline 2.275 & hoog & 49 & gemiddeld \\
\hline 525 & - & 61 & hoog \\
\hline 2.625 & gemiddeld & 56 & gemiddeld \\
\hline 275 & - & 61 & noog \\
\hline 2.250 & zeer hoog & 51 & gemiddeld \\
\hline- & - & - & - \\
\hline 325 & gemiddeld & 46 & laag \\
\hline 75 & - & 39 & zeer laag \\
\hline 1.900 & gemiddeld & 48 & gemiddeld \\
\hline 225 & * & 47 & laag \\
\hline 500 & gemiddeld & 57 & gemiddeld \\
\hline 3.950 & gemiddeld & 54 & gemiddeld \\
\hline- & - & - & - \\
\hline 25 & - & - & - \\
\hline 300 & gemiddeld & 54 & gemiddeld \\
\hline 800 & gemiddeld & 55 & gemiddeld \\
\hline 625 & gemiddeld & 59 & hoog \\
\hline - & - & - & - \\
\hline - & - & - & - \\
\hline 125 & - & 46 & laag \\
\hline - & - & - & - \\
\hline 75 & zeer laag & 45 & laag \\
\hline 550 & laag & 49 & gemiddeld \\
\hline - & - & - & - \\
\hline 275 & - & 77 & zeer hoog \\
\hline 425 & gemiddeld & 52 & gemiddeld \\
\hline - & - & - & - \\
\hline 275 & hoog & 56 & gemiddeld \\
\hline - & - & - & - \\
\hline - & - & - & - \\
\hline 50 & - & 44 & laag \\
\hline 100 & - & 46 & laag \\
\hline 100 & laag & 35 & zeer laag \\
\hline 75 & - & 49 & gemiddeld \\
\hline 75 & laag & 60 & hoog \\
\hline 50 & - & 70 & zeer hoog \\
\hline 125 & zeer laag & 59 & hoog \\
\hline 37.300 & & 56 & \\
\hline
\end{tabular}


Tabel 2.5

Niet-werkende werkzoekenden per beroepssegment en bemiddelingstase, Limburg, april 1999

Beroepssegment

Elementaire beroepen

Lagere niet-specialistische beroepen

Lagere docenten sportvakken

Lagere agrarische beroepen

Lagere wiskundige. natuurwetenschappelijke beroepen

Lagere technische beroepen

Lagere transportberoepen

Lagere (para)medische beroepen

Lagere administratieve, commerciële beroepen e.d.

Lagere beveiligingsberoepen

Lagere verzorgende beroepen

Middelbare docenten transport-, sportvakken

Middelbare agrarische beroepen

Middelbare wiskundige, natuurwetenschappelijke beroepen

Middelbare technische beroepen

Middelbare transportberoepen e.d.

Middelbare (para)medische beroepen

Middelbare administratieve, commerciële beroepen e.d.

Middelbare juridische, bestuurlijke, beveiligingsberoepen

Middelbare taalkundige, culturele beroepen

Middelbare beroepen m.b.t. gedrag en maatschappij

Middelbare verzorgende beroepen e.d.

Hogere pedagogische beroepen

Hogere landbouwkundige beroepen

Hogere wiskundige, natuurwetenschappelijke beroepen

Hogere technische beroepen

Hogere transportberoepen

Hogere (para)medische beroepen

Hogere aam . commerciële, economische beroepen

Hogere juridische, bestuurlijke, beveiligingsberoepen

Hogere taalkundige, culturele beroepen

Hogere beroepen m.b.t. gedrag en maatschappij

Hogere verzorgende beroepen

Managers ( $\mathrm{HBO}$ werk- en denkniveau) e.d

Wetenschappelijke pedagogische beroepen

Wetenschappelijke landbouwkundige beroepen

Wetenschappelijke wiskundige, natuurwet. beroepen

Wetenschappelijke technische beroepen

Wetenschappelijke (para)medische beroepen e.d.

Wetenschappelijke economische, adm. beroepen e.d.

Wetenschappelijke juridische, bestuurlijke beroepen

Wetenschappelijke beroepen m.b.t. gedrag en maatschappij

Managers (wetenschappelijk werk-en denkniveau)

Totaal

Bron: Arbeidsvoorziening/ROA

$\%$ fase 1 typering $\%$ fase $2+3$

14

20

37

37

24

13

20

18

22

30

30

26

31

18

23

-

27

23

36

-

28

38

32

-

16

31

25

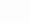

$-$

42

28

53

42

33

29

19 zeer laag

45

laag

hoog

gemiddeld

laag

gemiddeld

laag

gemiddeld

gemiddela

zeer hoog

gemiddeld

gemiddeld

laag

gemiddeld

-

gemiddeld

gemiddeld

hoog

gemiddeld

hoog

gemiddeld

-

laag

gemiddeld

gemiddeld

45

40

50

59

51

59

51

44

42

45

39

54

55

-

55

51

46

$-$

59

-

48

-

62

52

54

hoog

gemiddeld

zeer hoog

hoog

hoog

gemiddeld

47

47 
Tabel 2.6

Kenmerken niet-werkende werkzoekenden per beroepssegment, Limburg, april 1999

Beroepssegment

$\%$ vrouw $\%$ jong $\%$ oud

$(15-29) \quad(50-64)$

Elementaire beroepen

51

28

18

Lagere niet-specialistische beroepen

Lagere docenten sportvakken

Lagere agrarische beroepen

Lagere wiskundige, natuurwetenschappelijke beroepen

Lagere technische beroepen

Lagere transportberoepen

Lagere (para)medische beroepen

Lagere administratieve, commerciele beroepen e.d.

Lagere bevelligingsberoepen

Lagere verzorgende beroepen

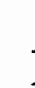

28

$-$

3

8

97

88

17

73

Middelbare docenten transport-, sportvakken

Middelbare agrarische beroepen

Middelbare wiskundige, natuurwetenschappelijke beroepen

Middelbare technische beroepen

Middelbare transportberoepen e.d.

Middelbare (para)medische beroepen

Middelbare administratieve, commercièle beroepen e.d.

Middelbare juridische, bestuurlijke, beveiligingsberoepen

Middelbare taalkundige, culturele beroepen

Middelbare beroepen m.b.t. gedrag en maatschappij

Middelbare verzorgende beroepen e.d.

Hogere pedagogische beroepen

Hogere landbouwkundige beroepen

Hogere wiskundige, natuurwetenschappelijke beroepen

Hogere technische beroepen

Hogere transportberoepen

Hogere (para)medische beroepen

Hogere administratieve, commerciéle, economische beroepen

Hogere juridische. bestuurlijke, beveiligingsberoepen

Hogere taalkundige. culturele beroepen

Hogere beroepen m.b.t gedrag en maatschappij

Hogere verzorgende beroepen

Managers (HBO werk- en denkniveau) e.d.

Wetenschappelijke pedagogische beroepen

Wetenschappelike landbouwkundige beroepen

Wotenschappelijke wiskundige, natuurwetenschappelijke beroepen

Wetenschappelijke technische beroepen

Wetenschappelijke (para)medische beroepen e.d.

Wetenschappelijke economische, administratieve beroepen e.d

Wetenschappelijke juridische, bestuurlijke beroepen

Wetenschappelijke beroepen m.b.t. gedrag en maatschappij

Managers (wetenschappelijk werk- en denkniveau)

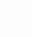


Tabel 2.7

Niet-werkende werkzoekenden per opleidingssector. Limburg, april 1999

\begin{tabular}{|c|c|c|c|c|}
\hline Opleidingssector & aantal & $\begin{array}{l}\text { typering } \\
\text { \% beroeps- } \\
\text { bevolking }\end{array}$ & $\begin{array}{r}\% \\
\text { langdurig } \\
\text { zoekend }\end{array}$ & typering \\
\hline Basisonderwijs & 6.500 & hoog & 73 & zeer hoog \\
\hline VMBO Theorie & 5.000 & hoog & 52 & gemiddeld \\
\hline VMBO Landbouw en natuurlijke omgeving & 400 & noog & 43 & laag \\
\hline VMBO Techniek & 5.200 & hoog & 52 & gemiddeld \\
\hline VMBO Economie & 3.000 & zeer hoog & 57 & gemiddeld \\
\hline VMBO Verzorging & 4.650 & zeer hoog & 64 & zeer hoog \\
\hline VMBO Openbare orde en veiligheid & 125 & - & 40 & zeer laag \\
\hline VMBO Totaal & 20.175 & hoog & 55 & gemiddeld \\
\hline HAVONWO & 1.850 & gemiddeld & 51 & gemiddeld \\
\hline MBO Landbouw en natuurlijke omgeving & 100 & zeer laag & 39 & zeer laag \\
\hline MBO Techniek & 2.675 & gemiddeld & 44 & laag \\
\hline MBO Dienstverlening en gezondheidszorg & 1.675 & gemiddeld & 55 & gemiddeld \\
\hline MBO Economie & 2.325 & gemiddeld & 45 & laag \\
\hline MBO Openbare orde en veiligheid & 50 & zeer laag & - & - \\
\hline MBO Totaal & 8.775 & gemiddeld & 47 & laag \\
\hline HBO Onderwijs en tolk en vertaler & 325 & laag & 61 & hoog \\
\hline HBO Landbouw & - & - & - & - \\
\hline HBO Techniek & 150 & zeer laag & 53 & gemiddeld \\
\hline HBO Paramedisch & 50 & zeer laag & - & - \\
\hline HBO Economie & 75 & zeer laag & 43 & laag \\
\hline HBO Sociaat-cultureel & 125 & laag & 60 & hoog \\
\hline HBO Kunst & 150 & gemiddeld & 69 & zeer hoog \\
\hline HBO Openbare orde en veiligheid & - & - & - & - \\
\hline HBO Totaal & 925 & laag & 57 & gemiddeld \\
\hline WO Totaal & 550 & laag & 55 & gemiddeld \\
\hline Totaal & 37.300 & & 56 & \\
\hline
\end{tabular}

Bron: Arbeidsvoorziening/ROA 
Tabel 2.8

Niet-werkende werkzoekenden per opleidingssector en bemıddelıngsfase, Limburg, april 1999

Opleidingssector

$\%$ fase

typering

$\%$ fase $2+3$

Basısonderwijs

8

zeer laag

40

VMBO Theorie

gemiddeld

VMBO Landbouw en natuurlijke omgeving

gemiddeld

gemiddeld

45

VMBO Techniek

VMBO Economie

gemiddeld

laag

VMIBO Openbare orde en veiligheid

gemiddeld

gemiddeld

VMBO Total

hoog

MBO Landbouw en natuurilike omgeving

31

hoog

hoog

gemiddeld

gemiddeld

MBO Dienstverlening en gezondheidszorg

MBO Economie

MBO Openbare orde en veiligheid

-

MBO Totaal

gemiddeld

44

58

46

55

48

HBO Onderwijs en tolk en vertaler

HBO Landbouw

HBO Techniek

gemiddeld

-

HBO Paramedisch

HBO Economie

gemiddeld

47

43

48

53

50

59

28

49

HBO Sociaal-cultureel

HBO Kunst

HBO Openbare orde en veiligheid

23

27

51

HBO Totaal

zeer hoog

gemiddeld

gemiddeld

4

40

20

19

-

24

gemiddeld

57

41

56

65

WO Totaal

22

gemiddeld

52

55

Totaal

19

47

Bron: Arbeidsvoorziening/ROA 
Tabel 2.9

Kenmerken niet-werkende werkzoekenden per opleidingssector, Limburg, april 1999

\begin{tabular}{|c|c|c|c|}
\hline Opleidingssector & $\%$ vrouw & $\begin{array}{c}\% \text { jong } \\
(15-29)\end{array}$ & $\begin{array}{l}\% \text { oud } \\
(50-64)\end{array}$ \\
\hline Basisonderwijs & 43 & 12 & 33 \\
\hline VMBO Theorie & 55 & 31 & 21 \\
\hline VMBO Landbouw en natuurlijke omgeving & 33 & 52 & 14 \\
\hline VMBO Techniek & 3 & 26 & 16 \\
\hline VMBO Economie & 71 & 21 & 13 \\
\hline VMBO Verzorging & 98 & 17 & 22 \\
\hline VMBO Openbare orde en veiligheid & - & 29 & - \\
\hline VMBO Totaal & 52 & 27 & 18 \\
\hline HAVONWO & 51 & 31 & 15 \\
\hline MBO Landbouw en natuurlijke omgeving & 37 & - & - \\
\hline MBO Technıek & 23 & 40 & 15 \\
\hline MBO Dienstverlening en gezondheidszorg & 80 & 32 & 17 \\
\hline MBO Economie & 52 & 46 & 12 \\
\hline MBO Openbare orde en veiligheid: & - & . & $=$ \\
\hline MBO Totaal & 48 & 37 & 15 \\
\hline HBO Onderwijs en tolk en vertaler & 61 & 22 & 26 \\
\hline HBO Landbouw & - & - & - \\
\hline HBO Techniek & - & 24 & 31 \\
\hline HBO Paramedisch & 83 & - & - \\
\hline HBO Economie & 45 & 40 & . \\
\hline HBO Sociaal-cultureel & 56 & 28 & - \\
\hline HBO Kunst & 43 & 17 & 19 \\
\hline HBO Openbare orde en veiligheid & - & - & - \\
\hline HBO Totaal & 47 & 24 & 24 \\
\hline WO Totaal & 40 & 25 & 18 \\
\hline Totaal & 49 & 27 & 20 \\
\hline
\end{tabular}

Bron: Arbeidsvoorziening/ROA 
Tabel 2.10

Discrepanties per bedriffssector. Limburg, april 1999

Bedriffssector

arbeidsmarktkrapte

typering

Landbouw en visserij

Voeding

Chemie

Metaal en elektrotechniek

Overige industrie

Energie

Bouw en onroerend goed

Handel

Transport en communicatie

Bank- en verzekeringswezen

Horeca, reparatie en zakelijke dienstverlening

Kwartaire diensten

0,80

1,47

1,60

1,81

1,78

1.62

1,91

2,84

2,20

1,66

2,30

2,60

1.70

laag

hoog

hoog

hoog

hoog

hoog

hoog

zeer hoog

zeer hoog

hoog

zeer hoog

zeer hoog

Overheid en onderwijs

1,99

Totaal

hoog

Bron: Arbeidsvoorziening/CBS/ROA 
Tabel 2.11

Discrepanties per beroepssegment, Limburg, april 1999

\section{Beroepssegment}

arbeidsmarktkrapte

typering

knelpunts-

indicator

Elementaire beroepen

1,38

hoog

0.12

Lagere niet-specialistische beroepen

Lagere docenten sportvakken

Lagere agrarische beroepen

Lagere wiskundige, natuurwet. beroepen

zeer hoog

-

Lagere technische beroepen

Lagere transportberoepen

hoog

hoog

zeer hoog

zeer hoog

zeer hoog

zeer hoog

0.12

Lagere adm., commercièle beroepen e.d.

9,63

2,54

3,89

Lagere beveiligingsberoepen

5,39

Lagere verzorgende beroepen

Middelbare docenten transport-, sportvakken

Middelbare agrarische beroepen

Middelbare wiskundige, natuurwet. beroepen

-

Middebare technische beroepen

Middelbare transportberoepen e.d.

hoog

1.46

Middelbare (para)medische beroepen

1,10

2.53

Middelbare adm., commerciële beroepen e.d.

1,66

Middelbare juridische. bestuurlijke, bev. beroepen

Middelbare taalkundige, culturele beroepen

Middelbare verzorgende beroepen e.d.

zeer hoog

hoog

zeer hoog

noog

Hogere pedagogische beroepen

Hogere landbouwkundige beroepen

Hogere wiskundige, nat. beroepen

Hogere technische beroepen

Hogere transportberoepen

Hogere (para)medische beroepen

Hogere adm., commerciële, ec. beroepen

Hogere juridische, bestuurijke, bev. beroepen

Hogere taalkundige, culturele beroepen

-

zeer hoog

zeer hoog

hoog

0,04

0,91

0.08

0,53

0,27

0,75

0.70

0,33

Hogere beroepen m.b.t. gedrag en maatschappij

Hogere verzorgende beroepen

Managers (HBO werk- en denkniveau) e.d

1,46

noog

0,36

-

-

$-$

zeer hoog

.

noog

0.20

1.79

-

- 
Tabel 2.12

Discrepanties per opleidingssector. Limburg, april 1999

\begin{tabular}{|c|c|c|c|}
\hline \multirow{2}{*}{$\begin{array}{l}\text { Opleidingstype } \\
\text { Basisonderwijs }\end{array}$} & arbeidsmarktkrapte & \multirow{2}{*}{$\begin{array}{l}\text { typering } \\
\text { zeer laag }\end{array}$} & \multirow{2}{*}{$\begin{array}{r}\begin{array}{r}\text { knelpunts- } \\
\text { indicator }\end{array} \\
-\end{array}$} \\
\hline & 0,35 & & \\
\hline VMBO Theorie & 0,68 & laag & - \\
\hline VMBO Landbouw en natuurlijke omgeving & 1,21 & hoog & 0,12 \\
\hline VMBO Techniek & 2,15 & zeer hoog & 0.59 \\
\hline VMBO Economie & 0,13 & zeer laag & - \\
\hline VMBO verzorging & 0,90 & laag & - \\
\hline VMBO Openbare orde en veiligherd & 2,08 & zeer hoog & 0,55 \\
\hline VMBO Totaal & 1,12 & hoog & 0,05 \\
\hline HAVONWO & 0,52 & laag & - \\
\hline MBO Landbouw en natuurlijke omgeving & 3.38 & zeer hoog & 2,15 \\
\hline MBO Techniek & 1,48 & hoog & 0,29 \\
\hline MBO Dienstverlening en gezondheidszorg & 2,33 & zeer hoog & 0,52 \\
\hline MBO Economie & 3,38 & zeer hoog & 1,31 \\
\hline MBO Openbare orde en veiligheid & . & $=$ & - \\
\hline MBO Totaal & 2,04 & zeer hoog & 0,58 \\
\hline HBO Onderwijs en tolk en vertaler & 4,45 & zeer hoog & 1,58 \\
\hline HBO Landbouw & - & - & - \\
\hline HBO Techniek & 9,15 & zeer hoog & 4,91 \\
\hline HBO Paramedisch & 12,50 & zeer hoog & 5,11 \\
\hline HBO Economie & 10,00 & zeer hoog & 8,71 \\
\hline HBO Sociaal-cultureel & 4,17 & zeer hoog & 1,12 \\
\hline HBO Kunst & - & - & - \\
\hline HBO Openbare orde en veiligheid & - & - & - \\
\hline HBO Totaal & 7,39 & zeer hoog & 2,94 \\
\hline Totaal & 1,99 & & 0,41 \\
\hline
\end{tabular}

Bron: Arbeidsvoorziening/CBS/ROA 
Tabel 3.1

Verwachte uitbreidingswraag per bedrifssector, Limburg, 2000 (percentage van de werkgelegenheid)

\begin{tabular}{lcl}
\hline Bedrifssector & $\%$ & typering \\
\hline Landbouw en visserij & 1,0 & gemiddeld \\
Voeding & 3,4 & erg hoog \\
Chemie & $-1,2$ & erg laag \\
Metaal en elektrotechniek & $-0,6$ & erg laag \\
Overige industrie & $-0,1$ & erg laag \\
Energie & $-1,0$ & erg laag \\
Bouw en onroerend goed & $-0,8$ & erg laag \\
Handel & 1,3 & gemiddeld \\
Transport en communicatie & 0,3 & laag \\
Bank en verzekeringswezen & $-0,3$ & erg laag \\
Horeca, reparatie en zakelijke dienstverlening & 3,2 & erg hoog \\
Kwartaire diensten & 1,8 & hoog \\
Overheid en onderwijs & $-0,8$ & erg laag \\
Totaal & & \\
\hline
\end{tabular}

Bron: ROATNO/Inro 
Tabel 3.2

Verwachte urtbreidingsvraag per beroepsgroep, Limburg. 2000 (percentage van de werkgelegenheid)

Leraar basisonderwijs

Docenten exacte. medische en verzorgende vakken ( 2 e graads)

Docenten exacte, medische en verzorgende vakken (1e graads)

Docenten landbouw en techniek (2e graads)

Docenten economisch-administratieve vakken (2e graads)

Docenten economisch-administratieve vakken (1e graads)

Docenten talen en expressie

Docenten letteren (1e graads)

Docenten sociale vakken (2e graads)

Docenten sociale vakken (1e graads)

Docenten $2 e$ graads zonder specialisatie

Onderwijskundig medewerkers

Onderwijskundigen en pedagogen

Rij-instructeurs

Zweminstructeurs

Sportinstructeurs

Tolken, vertalers en schrijvers

Bibliotheekassistenten

Bibliothecarissen

Grafisch ontwerpers

Kunstenaars

Geestelijken

Journalisten

Taalkundigen

Agrarische hulparbeiders

Agrarische arbeiders

Agrarische vakkrachten

Milieuhygienısten en agrarisch vertegenwoordigers

Landbouwmachinebestuurders en vissers

Agrarische bedrijfshoofden

Productiemedewerkers

Laboranten

Technisch analisten

Natuurwetenschappers

Concierges

Hoofden technische dienst

Werktuigbouwkundigen

Bouwwakkers

Aannemers en installateurs

Architecten en bouwkundig projectleiders

Weg- waterbouwkundigen

Weg- en waterbouwkundige arbeiders

Weg-en waterbouwkundige vakkrachten

Weg-en waterbouwkundig ontwerpers en projectleiders

Metaalarbeiciers

Bankwerkers en lassers

Bedrijfshoofden metaalbewerking

Assembleurs

Monteurs

Werktuigbouwkundig ontwerpers en hoofden technische dienst

Elektronicamonteurs

Monteurs en controleurs elektrotechnische producten

Elektromonteurs

Elektrotechnisch ontwerpers en bedrijfshoofden

Elektrotechnici

Grafisch productiepersoneel

Grafische vakkrachten

\begin{tabular}{|c|c|}
\hline \multicolumn{2}{|r|}{ gemiddeld } \\
\hline \\
\hline \multicolumn{2}{|r|}{$\begin{array}{l}\text { laag } \\
\text { gemiddeld }\end{array}$} \\
\hline \multirow{2}{*}{ - } & gemiddeld \\
\hline & gemiddeld \\
\hline \multicolumn{2}{|r|}{$\begin{array}{l}\text { gemiddeld } \\
\text { laag }\end{array}$} \\
\hline \multirow{2}{*}{-} & gemiddeld \\
\hline & gemiddeld \\
\hline \multirow{2}{*}{ - } & laag \\
\hline & gemiddeld \\
\hline \multirow{2}{*}{ - } & hoog \\
\hline & noog \\
\hline \multirow{2}{*}{ - } & gemiddeld \\
\hline & gemiddeld \\
\hline - & gemiddeld \\
\hline \multirow{2}{*}{ - } & erg laag \\
\hline & gemiddeld \\
\hline - & laag \\
\hline - & gemiddeld \\
\hline - & gemiddeld \\
\hline \multirow{2}{*}{ - } & hoog \\
\hline & erg hoog \\
\hline$-3,9$ & laag \\
\hline - & gemiddeld \\
\hline- & erg laag \\
\hline$-0,5$ & gemiddeld \\
\hline 2,9 & hoog \\
\hline & erg laag \\
\hline - & erg laag \\
\hline 27 & erg laag \\
\hline-2.1 & laag \\
\hline 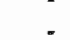 & erg laag \\
\hline-3.7 & laag \\
\hline 2,3 & hoog \\
\hline- & erg laag \\
\hline - & erg laag \\
\hline $20^{\circ}$ & erg laag \\
\hline & $\begin{array}{l}\text { noog } \\
\text { erc laag }\end{array}$ \\
\hline$-4,2$ & laag \\
\hline 1,7 & gemiddeld \\
\hline- & erg laag \\
\hline$-3,9$ & laag \\
\hline 0,4 & gemiddeld \\
\hline 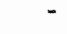 & erg laag \\
\hline b & hoog \\
\hline $22^{\circ}$ & erg laag \\
\hline & $\begin{array}{l}\text { hoog } \\
\text { erg laag }\end{array}$ \\
\hline - & erg laag \\
\hline - & erg laag \\
\hline 1,6 & gemiddeld \\
\hline
\end{tabular}




$\begin{array}{lll}\text { Beroepsgroep } & \% & \text { typering }\end{array}$

Mechanisch operators

Procesoperators

Procestechnologen

Materiaalkundigen

Confectie-arbeiders

Schoen- en kleermakers

Laders en lossers

Chauffeurs

Schippers en conducteurs

Vliegers, scheepskapiteins en leidinggevenden transport

Stewards

Verpleeghulpen en leerling-verpleegkundigen

Verplegenden en daktersassistenten

Therapeuten en verpleegkundigen

Artsen

Apothekersassistenten en medisch laboranten

Medisch analisten

Apothekers

Afdelingshoofden zorginstelling

Kantoorhulpen, inpakkers en colporteurs

Ondersteunende administratieve hulpkrachten

Bedrijfshoofden

Economen

Productieplanners

Organisatie-adviseurs

Organisatiedeskundigen

Receptionisten en administratieve employés

Boekhouders en secretaresses

Assistent accountants

Accountants

Verzekeringsagenten

Commercieel employés

Commercieel medewerkers

Technisch-commercieel employés

Technisch-bedrijfskundig medewerkers

Juridisch en fiscaal medewerkers

Juridisch, bestuurlijk medewerkers

Juristen

Admınistratieve transportemployes

Leidinggevenden

Managers

Medisch secretaresses

Programmeurs

Systeemanalisten

Informatici

Technisch systeemanalisten

Activiteitenbegeleiders en medewerkers arbeidsbemiddeling

Medewerkers sociaal-cultureel werk en personeel en arbeid

Hoofden sociaal-cultureel werk en personeel en arbeid

Sociaal-wetenschappelijk medewerkers

Sociaal-wetenschappelijk onderzoekers

Interieurverzorgers

Verkopers

Winkeliers

Hulpkrachten horeca en verzorging

Ziekenverzorgenden

Verzorgend personeel

Café- en snackbarhouders

\begin{tabular}{|c|c|}
\hline$-5,3$ & erg laag \\
\hline - & erg laag \\
\hline$=$ & erg laag \\
\hline - & erg laag \\
\hline-3.5 & laag \\
\hline - & erg hoog \\
\hline 4,1 & erg hoog \\
\hline$-0,7$ & gemiddeld \\
\hline - & erg laag \\
\hline$\cdot$ & laag \\
\hline- & hoog \\
\hline - & gemiddeld \\
\hline$-0,8$ & gemiddeld \\
\hline-0.1 & gemiddeld \\
\hline 0,6 & gemiddeld \\
\hline 0,9 & gemiddeld \\
\hline - & gemiddeld \\
\hline - & gemiddeld \\
\hline - & gemiddeld \\
\hline 4.1 & erg hoog \\
\hline - & erg laag \\
\hline- & hoog \\
\hline$=$ & erg laag \\
\hline 5,3 & erg hoog \\
\hline - & erg noog \\
\hline - & gemiddeld \\
\hline 3.4 & hoog \\
\hline 0.7 & gemiddeld \\
\hline 3,5 & hoog \\
\hline 0,7 & gemiddeld \\
\hline- & erg hoog \\
\hline$-1,7$ & gemiddeld \\
\hline 3,9 & erg hoog \\
\hline$\bullet$ & laag \\
\hline- & noog \\
\hline-0.7 & gemiddeld \\
\hline - & laag \\
\hline-0.5 & gemiddeld \\
\hline - & laag \\
\hline$-0,3$ & gemiddeld \\
\hline 0.5 & gemiddeld \\
\hline$\sim$ & hoog \\
\hline 1.1 & gemiddeld \\
\hline 5.8 & erg hoog \\
\hline • & laag \\
\hline- & erg laag \\
\hline 2,1 & hoog \\
\hline$-3,6$ & laag \\
\hline - & hoog \\
\hline - & laag \\
\hline - & hoog \\
\hline 4,2 & erg hoog \\
\hline 6,5 & erg hoog \\
\hline$-2,4$ & laag \\
\hline$-2,9$ & laag \\
\hline 4,4 & erg hoog \\
\hline 1,3 & gemiddeld \\
\hline - & gemiddeld \\
\hline
\end{tabular}


Tabel 3.2 (vervolg)

Verwachte utbreidingsuraag per beroepsgroep, Limburg, 2000 (percentage van de werkgelegenheid)

Beroepsgroep

$\%$

typering

Bedrijfshootden horeca

1,1

gemiddeld

Bakkers en slagers

Aspirant politieagenten, soldaten en beveiligingshulpkrachten

$-$

Politieagenten, onderofficieren en beveiligingsemployés

$-3,3$
$-2,6$

Politie-inspecteurs en officieren

Brandweerlieden

erg laag

laag

laiag

- laag

Totaal

0,7

Bron: ROA 
Verwachte vervangingsvraag per beroepsgroep. Limburg, 2000 (percentage van de werkgelegenheid)

typering

Leraar basisonderwijs

Docenten exacte, medische en verzorgende vakken ( 2 e graads)

Docenten exacte, medische en werzorgende vakken (le graads)

Docenten landbouw en techniek (2e graads)

Docenten economisch-administratieve vakken (2e graads)

Docenten economisch-administratieve vakken (1e graads)

Docenten talen en expressie

Docenten letteren (1e graads)

Docenten sociale vakken (2e graads)

Docenten sociale vakken ("e graads)

Docenten 2 e graads zonder specialisatie

Onderwijskundig medewerkers

Onderwijskundigen en pedagogen

Rij-instructeurs

Zweminstructeurs

Sportinstructeurs

Tolken, vertalers en schrijvers

Bibliotheekassistenten

Bibliothecarissen

Grafisch ontwerpers

Kunstenaars

Geestelijken

Journalisten

Taalkundigen

Agrarische hulparbeiders

Agrarische arbeiders

Agrarische vakkrachten

Milieuhygienisten en agrarisch vertegenwoordigers

Landbouwmachinebestuurders en vissers

Agrarische bedrijtshoofden

Productiemedewerkers

Laboranten

Technisch analisten

Natuurwetenschappers

Concierges

Hoofden technusche dienst

Werktuigbouwkundigen

Bouwvakkers

Aannemers en installateurs

Architecten en bouwkundig projectleiders

Weg-en waterbouwkundigen

Weg-en waterbouwkundige arbeiders

Weg-en waterbouwkundige vakkrachten

Weg- en waterbouwkundig ontwerpers en projectleiders

Metaalarbeiders

Bankwerkers en lassers

Bedrijfshoofden metaalbewerking

Assembleurs

Monteurs

Werktuigbouwkundig ontwerpers en hoofden technische dienst

Elektronicamonteurs

Monteurs en controleurs elektrotechnische producten

Elektromonteurs.

Elektrotechnisch ontwerpers en bedriffshoofden

Elektrotechnici

Grafisch productiepersoneel

Grafische vakkrachten

Mechanisch operators

\begin{tabular}{|c|c|}
\hline 4,0 & gemiddeld \\
\hline - & hoog \\
\hline - & erg hoog \\
\hline * & erg hoog \\
\hline- & erg hoog \\
\hline$=$ & gemiddeld \\
\hline 6,4 & erg hoog \\
\hline - & hoog \\
\hline - & erg hoog \\
\hline - & erg hoog \\
\hline- & hoog \\
\hline - & hoog \\
\hline - & gemiddeld \\
\hline - & hoog \\
\hline - & gemiddeld \\
\hline - & gemiddeld \\
\hline - & gemiddeld \\
\hline - & gemiddeld \\
\hline - & hoog \\
\hline- & erg laag \\
\hline- & gemiddeld \\
\hline - & hoog \\
\hline- & laag \\
\hline - & gemiddeld \\
\hline - & gemiddeld \\
\hline 4,0 & gemiddeld \\
\hline - & gemiddeld \\
\hline - & gemiddeld \\
\hline - & gemiddeld \\
\hline 4,1 & hoog \\
\hline 3,0 & gemiddeld \\
\hline - & gemiddeld \\
\hline - & hoog \\
\hline- & gemiddeld \\
\hline 5,5 & erg hoog \\
\hline - & hoog \\
\hline - & gemiddeld \\
\hline 3.7 & gemıddeld \\
\hline 3,3 & gemiddeld \\
\hline- & hoog \\
\hline- & hoog \\
\hline- & gemiddeld \\
\hline 4.0 & gemiddeld \\
\hline - & gemiddeld \\
\hline 3.9 & gemiddeld \\
\hline 3,2 & gemiddeld \\
\hline 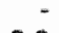 & erg hoog \\
\hline 3,3 & gemiddeld \\
\hline 3,1 & gemiddeld \\
\hline - & hoog \\
\hline - & hoog \\
\hline$=$ & gemiddeld \\
\hline 3,7 & gemiddeld \\
\hline - & hoog \\
\hline- & laag \\
\hline 5 & gemiddeld \\
\hline 3,3 & gemiddeld \\
\hline 4,2 & hoog \\
\hline
\end{tabular}


Tabel 3.3 (vervolg)

Verwachte vervangingsvraag per beroepsgroep. Limburg, 2000 (percentage van de werkgelegenheid)

Beroepsgroep

$\%$

typering

Procesoperators

Procestechnologen

Materiaalkundigen

Confectie-arbeiders

gemiddeld

hoog

lakers

gemiddeld

Laders en lossers

erg hoog

Chauffeurs

Schippers en conducteurs

Vliegers, scheepskapiteins en leidinggevenden transport

Stewards

Verpleeghulpen en leerling-verpleegkundigen

hoog

2,1

3,4

erg laag

Verplegenden en doktersassistenten

gemiddeld

gemiddeld

gemiddeld

gemiddeld

gemiddeld

Therapeuten en verpleegkundigen

hoog

Artsen

4,0

3,0

Apothekersassistenten en medisch laboranten

4,0

Medisch analisten

Apothekers

Afdelingshoofden zorginstelling

Kantoorhulpen, inpakkers en colporteurs

Ondersteunende administratieve hulpkrachten

Bedrijfshoofden

Economen

Productieplanners

Organisatie-adviseurs

Organisatiedeskundigen

Receptionisten en administratieve employès

gemiddeld

gemiddeld

gemiddeld

gemiddeld

gemiddeld

$2,3 \quad$ laag

hoog

gemiddeld

laag

2.3

laag

erg laag

laag

Boekhouders en secretaresses

6,2

2,5

erg hoog

Assistent accountants

Accountants

Verzekeringsagenten

laag

gemiddeld

laag

Commercieel employés

Commercieel medewerkers

Technisch-commercieel employes

Technisch-bedrijfskundig medewerkers

gemiddeld

gemiddeld

$$
\text { laag }
$$

gemiddeld

Juridisch en fiscaal medewerkers

gemiddeld

Juridisch, bestuurlijk medewerkers

gemiddeld

Juristen

erg hoog

Administratieve transportemployés

laag

Leidinggevenden

gemiddeld

Managers

Medisch secretaresses

gemiddeld

hoog

Programmeurs

Systemanalisten

Informatici

Technisch systeemanalisten

Activiteitenbegeleiders en medewerkers arbeidsbemiddeling

gemiddeld

erg laag

1,7

1,7

erg laag

Medewerkers sociaal-cultureel werk en personeel en arbeid

erg laag

erg laag

Hoofden sociaal-cultureel werk en personeel en arbeid

Sociaal-wetenschappelijk medewerkers

Sociaal-wetenschappelijk onderzoekers

Interieurverzorgers

$$
\text { erg laag }
$$

2,2

3,1

gemiddeld

gemiddeld

Verkopers

Winkeliers

Hulpkrachten horeca en verzorging

Ziekenverzorgenden

Verzorgend personeel

Café - en snackbarhouders

Bedrijfshoofden horeca

\section{hoog}

laag 
Tabel 3.3 (vervolg)

Verwachte vervangingsvraag per beroepsgroep, Limburg, 2000 (percentage van de werkgelegenheid)

Beroepsgroep

$\% \quad$ typering

Bakkers en slagers

Aspirant politieagenten, soldaten en beveiligingshulpkrachten

Politieagenten, onderofficieren en beveiligingsemployès

gemiddeld

Politie-inspecteurs en officieren

Brandweerlieden

gemiddeld

gemiddeld

gemiddeld

hoog

Totaal

3,6

Bron: ROA 
Tabel 3.4

Verwachte baanopeningen per beroepsgroep. Limburg, 2000 (percentage van de werkgelegenheid)

Leraar basisonderwijs

Docenten exacte, medische en verzorgende vakken (2e graads)

Dacenten exacte, medische en verzorgende vakken (le graads)

Docenten landbouw en techniek (2e graads)

Docenten economisch-administratieve vakken (2e graads)

Docenten economisch-administratteve vakken (1e graads)

Docenten talen en expressie

Docenten letteren (1e graads)

Docenten sociale vakken (2e graads)

Docenten sociale vakken (1e graads)

Docenten $2 e$ graads zonder specialisatie

Onderwijskundig medewerkers

Onderwijskundigen en pedagogen

Rij-instructeurs

Zweminstructeurs

Sportinstructeurs

Tolken, vertalers en schrijvers

Bibliotheekassistenten

Bibliothecarissen

Grafisch ontwerpers

Kunstenaars

Geestelijken

Journalisten

Taalkundigen

Agrarische hulparbeiders

Agrarische arbeiders

Agrarische vakkrachten

Milieuhygiënisten en agrarisch vertegenwoordigers

Landbouwmachinebestuurders en vissers

Agrarische bedrijfshoofden

Productiemedewerkers

Laboranten

Technisch analisten

Natuurwetenschappers

Concierges

Hoofden technische dienst

Werktuigbouwkundigen

Bouwrakkers

Aannemers en installateurs

Architecten en bouwkundig projectleiders

Weg-en waterbouwkundigen

Weg en waterbouwkundige arbeiders

Weg-en waterbouwkundige vakkrachten

Weg-en waterbouwkundig ontwerpers en projectleiders

Metaalarbeiders

Bankwerkers en lassers

Bedrijfshoofden metaalbewerking

Assembleurs

Monteurs

Werktuigbouwkundig ontwerpers en hoofden technische dienst

Elektronicamonteurs

Monteurs en controleurs elektrotechnische producten

Elektromonteurs

Elektrotechnisch ontwerpers en bedriffshoofden

Elektrotechnici

Grafisch productiepersoneel

Grafische vakkrachten

Mechanisch operators
4,0

gemiddeld

gemiddeld

hoog

hoog

hoog

gemiddeld

hoog

gemidideld

hoog

hoog

gemiddeld

hoog

hoog

hoog

gemidideld

gemiddeld

gemiddeld

gemiddeld

gemiddeld

erg laag

gemiddeid

gemiddeld

laag

gemiddeld

hoog

4.0

gemiddeld

gemiddeld

gemiddeld

gemiddeld

4.1

5,9

gemiddeld

hoog

gemiddeld

gemiddeld

gemidideld

gemiddeld

hoog

gemiddald

gemiddeld

gemiddeld

gemiddela

gemiddeld

gemiddeld

hoog

gemiddeld

gemiddeld

gemiddeld

hoog

gemiddeld

gemiddeld

gemiddeld

hoog

gemiddeld

hoog

gemiddeld

laag

gemiddeld

gemiddeld

gemiddeld 
Tabel 3.4 (vervolg)

Verwachte baanopeningen per beroepsgroep. Limburg, 2000 (percentage van de werkgelegentheid)

Procesoperators

Procestechnologen

Materiaalkundigen

Confectie-arbeiders

Schoen- en kleermakers

Laders en lossers

Chauffeurs

Schippers en conducteurs

Vliegers, scheepskapiteins en leidinggevenden transpiort

Stewards

Verpleeghulpen en leerling-verpleegkundigen

Verplegenden en doktersassistenten

Therapeuten en verpleegkundigen

Artsen

Apothekersassistenten en medisch laboranten

Medisch analisten

Apothekers

Afdelingshoofden zorginstelling

Kantoorhulpen, inpakkers en colporteurs

Ondersteunende administratieve hulpkrachten

Bedrijfshoofden

Economen

Productieplanners

Organisatie-adviseurs

Organisatiedeskundigen

Receptionisten en adminıstratieve employés

Boekhouders en secretaresses

Assistent accountants

Accountants

Verzekeringsagenten

Commercieel employés

Commercieel medewerkers

Technisch-commercieel employés

Technisch-bedrijfskundig medewerkers

Jundisch en fiscaal medewerkers

Juridisch, bestuurlijk medewerkers

Juristen

Administratieve transportemployés

Leidinggevenden

Managers

Medisch secretaresses

Programmeurs

Systeemanalisten

informatici

Technisch systeemanalisten

Activiteitenbegeleiders en medewerkers arbeidsbemiddeling

Medewerkers sociaal-cultureel werk en personeel en arbeid

Hoofden sociaal-cultureel werk en personeel en arbeid

Sociaal-wetenschappelijk medewerkers

Sociaal-wetenschappelijk onderzoekers

Interieurverzorgers

Verkopers.

Winkeliers

Hulpkrachten horeca en verzorging

Ziekenverzorgenden

Verzorgend personeel

Café- en snackbarhouders

Bedrijfshoofden horecal

\begin{tabular}{|c|c|}
\hline - & erg laag \\
\hline$=$ & gemiddeld \\
\hline * & gemiddeld \\
\hline 5.4 & gemiddeld \\
\hline$=$ & erg hoog \\
\hline 6.2 & hoog \\
\hline 3,4 & gemiddeld \\
\hline = & gemiddeld \\
\hline - & gemiddeld \\
\hline - & hoog \\
\hline- & gemiddeld \\
\hline 4,6 & gemiddeld \\
\hline 4,0 & gemiddeld \\
\hline 3,6 & gemiddeld \\
\hline 4,9 & gemiddeld \\
\hline - & gemiddeld \\
\hline$=$ & gemiddeld \\
\hline- & hoog \\
\hline 6,4 & hoog \\
\hline$\cdot$ & gemiddeld \\
\hline - & hoog \\
\hline$=$ & laag \\
\hline 7,6 & hoog \\
\hline- & erg hoog \\
\hline- & laag \\
\hline 9,6 & erg hoog \\
\hline 3,2 & gemiddeld \\
\hline 6,3 & hoog \\
\hline 3,3 & gemiddeld \\
\hline- & erg hoog \\
\hline 3,1 & gemiddeld \\
\hline 6,4 & hoog \\
\hline - & gemiddeld \\
\hline 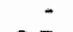 & gemiddeid \\
\hline 3,7 & gemiddeld \\
\hline - & hoog \\
\hline 2.7 & latag \\
\hline- & gemiddeld \\
\hline 3.8 & gemiddeld \\
\hline 5,0 & gemiddeld \\
\hline “ & gemıdideld \\
\hline 2,8 & gemudideld \\
\hline 7.5 & hoog \\
\hline - & erg laag \\
\hline- & erg laag \\
\hline 4,3 & gemıddeld \\
\hline 3,1 & gemiddeld \\
\hline$*$ & hoog \\
\hline$=$ & gemiddeld \\
\hline- & gemiddeld \\
\hline 7,6 & hoog \\
\hline 10,4 & ergl hoog \\
\hline 4,1 & gemiddeld \\
\hline 4,8 & gemiddeld \\
\hline 6.9 & hoog \\
\hline 4,9 & gemiddeld \\
\hline 56 & og \\
\hline 5,6 & mido \\
\hline
\end{tabular}


Tabel 3.4 (vervolg)

Verwachte baanopeningen per beroepsgroep. Limburg. 2000 (percentage van de werkgelegenheid)

Beroepsgroep $\quad \% \quad$ typering

Bakkers en slagers

Aspirant politieagenten, soldaten en beveiligingshulpkrachten

3,3

Politieagenten, onderofficieren en beveiligingsemployes

Politie-inspecteurs en officieren

Brandweerlieden

erg laag

gemiddeld

- $\quad$ gemiddeld

Totaal

5.4

Bron: ROA 
Tabel 3.5

Verwachte arbeidsmarktinstroom van schoolverlaters naar beroepsgroep. Limburg, 2000 (percentage van de werkgelegenheid)

instroom typering

$\%$

Rij-instructeurs

Zweminstructeurs

Sportinstructeurs

Bibliotheekassistenten

Grafisch ontwerpers

Agrarische hulparbetders

Agrarische arbeiders

Agrarische vakkrachten

Landbouwmachinebestuurders en vissers

Agrarische bedriffshoofden

Productiemedewerkers

Laboranten

Conciêrges

Hoofden technische dienst

Bouwvakkers

Aannemers en installateurs

Weg-en waterbouwkundige arbeiders

Weg-en waterbouwkundige vakkrachten

Metaalarbeiders

Bankwerkers en lassers

Assembleurs

Monteurs

Elektronicamonteurs

Monteurs en controleurs elektrotechnische producten

Elektromonteurs

Grafisch productiepersoneel

Grafische vakkrachten

Mechanisch operators

Procesoperators

Confectie-arbeiders

Schoen-en kleermakers

Laders en lossers

Chauffeurs

Schippers en conducteurs

Stewards

Verpleeghulpen en leerling-verpleegkundigen

Verplegenden en doktersassistenten

Apothekersassistenten en medisch laboranten

Kantoorhulpen, inpakkers en colporteurs

Ondersteunende administratteve hulpkrachten

Productieplanners

Receptionisten en adminıstratieve employés

Boekhouders en secretaresses

Verzekeringsagenten

Commercieel employes

Technisch-commercieel employés

Juridisch en fiscaal medewerkers

Administratieve transportemployès

Medisch secretaresses

Programmeurs

Activiteitenbegeleiders en medewerkers arbeidsbemiddeling

Interieurverzorgers

Verkopers

Winkeliers

Hulpkrachten horeca en verzorging

Ziekenverzorgenden

\section{laag}

erg hoog

gemiddeld

hoog

erg hoog

gemiddeld

gemiddeld

hoog

erg hoog

gemiddeld

hoog

gemiddeld

gemiddeld

gemiddeld

gemiddeld

hoog

gemiddeld

gemiddeld

gemiddeld

gemiddeld

laag

gemiddeld

gemiddeld

gemiddeld

hoog

4,1

gemiddeld

erg hoog

gemiddeld

erg laag

gemiddeld

hoog

erg hoog

gemiddeld

hoog

erg hoog

hoog

hoog

gemiddeld

hoog

laag

erg hoog

hoog

hoog

erg hoog

hoog

gemiddeld

gemiddeld

gemiddeld

hoog

erg hoog

erg hoog

hoog

hoog

gemiddeld

hoog

hoog 
Tabel 3.5 (vervolg)

Verwachte arbeidsmarktinstroom van schoolverlaters naar beroepsgroep, Limburg, 2000 (percentage van de werkgelegenheid)

Beroepsgroep

instroom

typering

$\%$

Verzorgend personeel

Caté-en snackbarhouders

Bedriffshoofden horeca

Bakkers en slagers

Aspirant politieagenten, soldaten en beveiligingshulpkrachten

Politieagenten, onderofficieren en bevelligingsemployes

Brandweerlieden

$4,2 \quad$ hoog

- gemiddeld

4.1 hoog

- erg laag

6,3 erg hoog

$3,0 \quad$ gemiddeld

- gemiddeld

Totaal

4,2

Bron: ROA 
Tabel 3.6

Indicator Toekomstige Arbeidsmarktpositie naar Beroep (ITAB) en Indicator Toekomstige Knelpunten in de personeelsvoorziening naar Beroep (ITKB), Limburg, 2000

ITAB typering ITKB typering

Rij-instructeurs

Zweminstructeurs

Sportinstructeurs

Bibliotheekassistenten

Grafisch ontwerpers

Agrarische hulparbeiders

Agrarische arbeiders

Agrarische vakkrachten

Landbouwmachinebestuurders en vissers

Agrarische bedriffshoofden

Productiemedewerkers

Laboranten

Conciërges

Hoofden technısche dienst

Bouwvakkers

Aannemers en installateurs

Weg- en waterbouwkundige arbeiders

Weg-en waterbouwkundige vakkrachten

Metaalarbeiders

Bankwerkers en lassers

Assembleurs

Monteurs

Elektronicamonteurs

Monteurs en controleurs elektrotechnische producten

Elektromonteurs

Grafisch productiepersoneel

Grafische vakkrachten

Mechanisch operators

Procesoperators

Confectie-arbeiders

Schoen- en kleermakers

Laders en lossers

Chauffeurs

Schippers en conducteurs

Stewards

Verpleeghulpen en leerling-verpleegkundigen

Verplegenden en doktersassistenten

Apothekersassistenten en medisch laboranten

Kantoorhulpen, inpakkers en colporteurs

Ondersteunende admınistratieve hulpkrachten

Productieplanners

Receptıonısten en admınıstratıeve employés

Boekhouders en secretaresses

Verzekeringsagenten

Commercieel employés

Technisch-commercieel employés

Juridisch en fiscaal medewerkers

Administratieve transportemployés

Medisch secretaresses

Programmeurs

Activiteitenbegeleiders en medewerkers arbeidsbemiddeling

Interieurverzorgers

Verkopers

Winkeliers

Hulpkrachten horeca en verzorging

Ziekenverzorgenden

Verzorgend personeel

(20)


Tabel 36 (vervolg)

Indicator Toekomstige Arbeidsmarktpositie naar Beroep (ITAB) en Indıcator Toekomstige Knelpunten in de personeelswoorziening naar Beroep (ITKB), Limburg, 2000

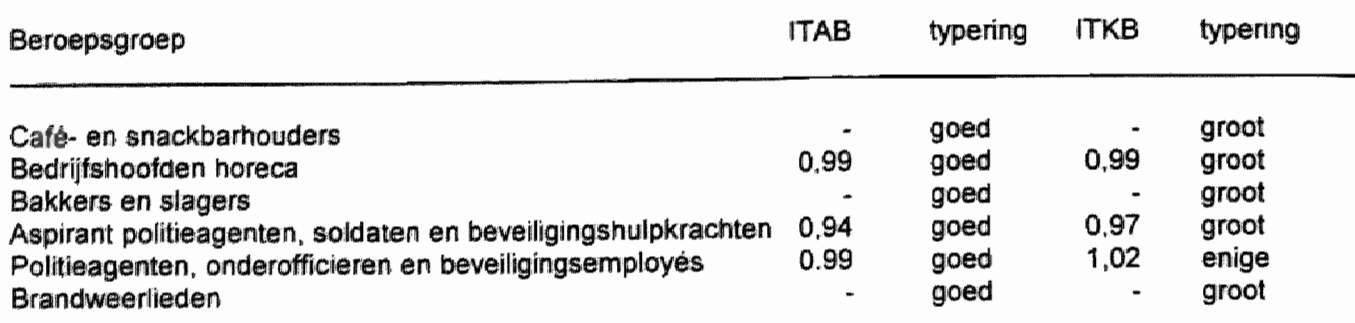

Bron: ROA 
Verwachte uitbreidingswraag per opleidingstype, Limburg, 2000 (percentage van de werkgelegenheid)

$\begin{array}{lll} & & \text { typering }\end{array}$

\section{Basisonderwijs}

VMBO theorie

VMBO landbouw en natuurlijke omgeving

VMBO bouwtechniek

VMBO installatietechniek

VMBO metaal: mechanische techniek

VMBO voertuigentechniek

VMBO elektrotechniek

VMBO grafische techniek

VMBO brood en banket

VMBO consumptief en levensmiddelentechniek

VMBO transport en logistiek

VMBO administratie, handel en mode

VMBO (uiterlijke) verzorging

VMBO beveiliging

HAVONWO

$\mathrm{MBO}$ landbouw en veeteelt

MBO milieu en groene ruimte

MBO laboratorium

MBO bouw

MBO grond-, weg- en waterbouw

$M B O$ installatietechniek

MBO werktuigbouw en mechanische techniek

MBO fijnmechanische techniek

MBO motorvoertuigentechniek

MBO viegtuigtechniek

MBO operationele techniek

MBO elektrotechniek

MBO grafische techniek

MBO procestechniek

MBO brood en banket

MBO levensmiddelentechniek/vleesverwerking

$M B O$ vervoer en logistiek

MBO dokters-, tandarts- en dierenartsassistent

$\mathrm{MBO}$ apothekersassistent

$M B O$ verpleging

MBO gezondheidstechniek

$M B O$ sociaal-cultureel

$M B O$ verzorging

$M B O$ uiterijke verzorging

MBO horeca

$M B O$ beweging en therapie

MBO administratie

MBO handel

MBO secretariaat

MBO toerisme en recreatie

$M B O$ openbare orde en veiligheid

$\mathrm{HBO}$ lerarenopleiding basisonderwijs

HBO lerarenopleiding talen

$\mathrm{HBO}$ lerarenopleiding natuur en techniek

$\mathrm{HBO}$ lerarenopleiding economie en maatschappij

$\mathrm{HBO}$ lerarenopleiding lichamelijke opvoeding

$\mathrm{HBO}$ lerarenopleiding medisch en verzorging

$\mathrm{HBO}$ lerarenopleiding expressie

$\mathrm{HBO}$ tolk en vertaler

$\mathrm{HBO}$ landbouw en veeteelt

HBO milieukunde en levensmiddelentechnologie

$\mathrm{HBO}$ laboratorium
$-2,9$

0.7

$-4,4$

$-2.0$

$-3.5$

$-3,1$

$-0,3$

$-$

$+$

$-2,9$

$-2,1$

1, 0

2,7

1,7

-

2,7

2,7

2.3

0.0

18

1.8

2

2.2

$-1.9$

4,2

$-$

2,4

-

0,9

2,9

$-0,3$

2.7

3,7

$-0.4$

0,8

0.0

2. 3

$-0.5$

1,1

$-4,3$

$-0,8$

1.7

:

$-1,9$

$-1.9$

-

$-3,2$ laag

gemiddeld

erg laag

laag

laag

erg laag

larg

laag

erg laag

erg laag

laag

laag

laag

gemiddeld

gemiddeld

gemiddeld

gemiddeld

gemiddeld

erg laag

gemiddeld

gemiddeld

gemiddeld

laag

laag

gemiddeld

laag

gemiddeid

gemiddeld

laag

hoog

laag

gemiddeld

gemiddeld

gemiddeld

hoog

gemiddeld

hoog

gemiddeld

laag

gemiddeld

hoog

laag

gemiddeld

gemiddeld

gemiddeld

gemiddeld

laag

gemiddeld

erg laag

laag

gemiddeld

laag

laag

laag

gemiddeld

erg hoog

laag

erg laag 
Tabel 3.7 (vervolg)

Verwachte uitbreidingsvraag per opleidingstype, Limburg, 2000 (percentage van de werkgelegenheid)

Opleidingstype

HBO bouwkunde

HBO civiele techniek

HBO werkturgbouwkunde

HBO elektrotechniek

$\mathrm{HBO}$ informatica

HBO chemische technologie

HBO vervoer en logustiek

HBO verpleegkunde

HBO (fysio)therapie

$\mathrm{HBO}$ voeding

$H B O$ accountancy en bedrijfseconomie

HBO commerciele economie

$\mathrm{HBO}$ toerisme en recreatie

HBO recht en bestuur

HBO secretariaat

$\mathrm{HBO}$ bedrijfskunde

HBO communicatie en journalistiek

HBO maatschappelijk werk en hulpverlening

$\mathrm{HBO}$ personeel en arbeid

HBO bibliotheek en documentatie

HBO uitvoerende en beeldende kunsten

HBO openbare orde en veiligheid

WO letteren

WO theologie

WO landbouw en milieukunde

WO wiskunde en natuurwetenschappen

WO bouwkunde

WO civiele techniek

WO werktuigbouwkunde

WO elektrotechniek

WO informatica en bestuurlijke informatrekunde

WO (dier)geneeskunde

WO tandheelkunde

WO farmacie

WO econom(etr)ie

WO bedriffskunde

WO accountancy en belastingen

WO rechten en bestuurskunde

WO sociale wetenschappen

WO kunstwetenschappen
$\%$

typering

gemiddeld

laag

gemiddeld

gemiddeld

erg hoog

laag

gemiddeld

gemiddeld

hoog

hoog

gemiddeld

hoog

hoog

hoog

gemiddeld

hoog

erg hoog

laag

laag

gemiddeld

gemiddeld

laag

gemiddeld

laag

gemiddeld

laag

erg laag

erg laag

laag

gemiddeld

erg hoog

laag

gemiddeld

laag

hoog

hoog

hoog

gemiddeld

gemiddeld

gemiddeld

Totaal

0.7

Bron. ROA 
Verwachte vervangingsvraag per opleidingstype, Limburg, 2000 (percentage van de werkgelegenheid)

$\begin{array}{lll}\text { Opleidingstype } & \% & \text { typering }\end{array}$

Basisonderwijs

VMBO theorie

VMBO landbouw en natuurijike omgeving

VMBO bouwtechniek

VMBO installatietechniek

VMBO metaal. mechanische techniek

VMBO voertuigentechniek

VMBO elektrotechniek

VMBO grafische techniek

VMBO brood en banket

VMBO consumptief en levensmiddelentechniek

VMBO transport en logistiek

VMBO administratie, handel en mode

VMBO (uiterlijke) verzorging

VMBO beveiliging

HAVONWO

MBO landbouw en veeteelt

MBO milieu en groene ruimte

$M B O$ laboratorium

MBO bouw

MBO grond-, weg- en waterbouw

MBO installatietechniek

MBO werktuigbo'uw en mechanische techniek

MBO fijnmechanische techniek

MBO motorvoertuigentechniek

MBO vliegtuigtechniek

MBO operationele techniek

MBO elektrotechniek

MBO grafische techniek

MBO procestechniek

MBO brood en banket

MBO levensmiddelentechniek/vleesverwerking

MBO vervoer en logistiek

MBO dokters- tandarts- en dierenartsassistent

MBO apothekersassistent

$M B O$ verpleging

MBO gezondheidstechniek

MBO socialal-cultureel

MBO verzorging

MBO uiterlijke verzorging

MBO horeca

MBO beweging en therapie

MBO administratie

MBO handel

MBO secretariaat

MBO toerisme en recreatie

MBO openbare orde en veiligheid

$\mathrm{HBO}$ lerarenopleiding basisonderwijs

$\mathrm{HBO}$ lerarenopleiding talen

$\mathrm{HBO}$ lerarenopleiding natuur en techniek

$\mathrm{HBO}$ lerarenopleiding economie en maatschappil

$\mathrm{HBO}$ lerarenopleiding lichamelijke opwoeding

$\mathrm{HBO}$ lerarenopleiding medisch en verzorging

HBO lerarenopleiding expressie

HBO tolk en vertaler

$\mathrm{HBO}$ landbouw en veeteelt

HBO milieukunde en levensmiddelentechnologie

$\mathrm{HBO}$ laboratorium
4.4

5,9

3,6

4,5

5,5

2,9

6.4

-

-

3.9

5,6

6.3

6.1

4,9

-

2.9

3.1

5.3

$3, \overline{2}$

$-$

3,3

4,9

2.3

-

3,4

.

3.6

4,2

5,3

4.7

2.9

4.5

3.4

4. 3

4.1

3,2

5,0

6,6

4,6

5,0

-

6,2

-

5,9 gemiddeld

hoog

gemiddeld

gemiddeld

erg hoog

hoog

laag

eng hoog

erg hoog

hoog

hoog

gemiddeld

hoog

erg hoog

gemiddeld

erg hoog

hoog

laag

gemiddeld

laag

gemiddeld

laag

hoog

gemiddeld

laag

gemiddeld

laag

gemiddeld

hoog

erg laag

gemiddeld

gemiddeld

gemiddeld

gemiddeld

erg hoog

gemiddeld

laag

gemiddeld

hoog

gemiddeld

laag

gemiddeld

gemiddeld

gemiddeld

gemiddeld

erg laag

laag

hoog

erg hoog

gemiddeld

hoog

hoog

hoog

erg hoog

erg laag

laag

laag

hoog 
Taber 3.8 (vervolg)

Verwachte vervangingswraag per opleidingstype, Limburg, 2000 (percentage van de werkgelegenheid)

\begin{tabular}{|c|c|c|}
\hline Opleidingstype & $\%$ & typering \\
\hline HBO bouwkunde & - & gemiddeld \\
\hline HBO civiele techniek & $\cdot$ & gemiddeld \\
\hline HBO werktuigbouwkunde & 5,2 & hoog \\
\hline HBO elektrotechniek & 4.5 & gemiddeld \\
\hline HBO informatica & 3,2 & laag \\
\hline HBO chemische technologie & - & erg hoog \\
\hline $\mathrm{HBO}$ vervoer en logistiek & - & gemiddeld \\
\hline $\mathrm{HBO}$ verpleegkunde & 3.9 & gemiddeld \\
\hline HBO (fysio)therapie & 2,4 & erg laag \\
\hline HBO voeding & - & laag \\
\hline HBO accountancy en bedriffseconomie & 3,6 & gemiddeld \\
\hline HBO commercielé economie & 2,1 & erg laag \\
\hline HBO toerisme en recreatie & - & laag \\
\hline HBO recht en bestuur & - & laag \\
\hline HBO secretariaat & 8,9 & erg hoog \\
\hline $\mathrm{HBO}$ bedrifiskunde & 2.1 & erg laag \\
\hline HBO communicate en journalistiek & - & erg laag \\
\hline HBO maatschappellijk werk en huipverlening & 4.5 & gemiddeld \\
\hline HBO personeel en arbeld & - & gemiddeld \\
\hline HBO bibliotheek en documentatie & - & hoog \\
\hline HBO uitvoerende en beeldende kunsten & 3.9 & gemiddeld \\
\hline HBO openbare orde en veiligheid & - & erg hoog \\
\hline WO letteren & $\cdot$ & laag \\
\hline WO theologie & - & hoog \\
\hline WO landbouw en milieukunde & - & erg laag \\
\hline WO wiskunde en natuurwetenschappen & 3.7 & gemiddeld \\
\hline WO bouwkunde & - & gemiddeld \\
\hline WO civiele techniek & - & hoog \\
\hline WO werktuigbouwkunde & - & laag \\
\hline WO elektrotechniek & - & laag \\
\hline WO informatica en bestuurlijke informatiekunde & - & erg laag \\
\hline WO (dier)geneeskunde & 4,1 & gemiddeld \\
\hline WO tancheelkunde & - & gemiddeid \\
\hline WO farmacie & - & laag \\
\hline WO econom(etr)le & 3,0 & laag \\
\hline WO bedrijfskunde & - & erg laag \\
\hline WO accountancy en belastingen & - & gemiddeld \\
\hline WO rechten en bestuurskunde & 3.4 & gemiddeld \\
\hline WO sociale wetenschappen & 3.3 & gemiddeld \\
\hline WO kunstwetenschappen & - & erg laag \\
\hline Totaral & 4.4 & \\
\hline
\end{tabular}

Bron ROA 
Verwachte baanopeningen per opleidingstype, Limburg, 2000 (percentage van de werkgelegenheid)

Basisonderwijs

VMBO theorie

VMBO landbouw en natuurlijke omgeving

VMBO bouwtechniek

VMBO installatietechniek

VMBO metaal: mechanische techniek

VMBO voertuigentechnie $k$

VMBO elektrotechniek

VMBO grafische techniek

VMBO brood en banket

VMBO consumptief en levensmiddelentechniek

VMBO transport en logistiek

VMBO administratie, handel en mode

VMBO (uiterlijke) verzorging

VMBO beveiliging

HAVOMWO

MBO landbouw en veeteelt

MBO milieu en groene ruimte

MBO laboratorium

MBO bouw

MBO grond-, weg- en waterbouw

$M B O$ installatietechniek

MBO werktuigbouw en mechanische techniek

MBO fijnmechanische techniek

MBO motorvoertuigentechniek

MBO vliegtuigtechniek

MBO operationele techniek

MBO elektrotechniek

MBO grafische techniek

MBO procestechniek

MBO brood en banket

MBO levensmiddelentechniek/vleesverwerking

$M B O$ vervoer en logistiek

MBO dokters-, tandarts- en dierenartsassistent

MBO apothekersassistent

$M B O$ verpleging

MBO gezondheidstechniek

MBO sociaal-cultureel

$M B O$ verzorging

MBO uiterlijke verzorging

MBO horeca

MBO beweging en therapie

MBO administratie

MBO handel

MBO secretariaat

MBO toerisme en recreatie

MBO openbare orde en veiligheid

$H B O$ lerarenopleiding basisonderwijs

$\mathrm{HBO}$ lerarenopleiding talen

HBO lerarenopleiding natuur en techniek

HBO lerarenopleiding economie en maatschappij

HBO lerarenopleiding lichamelijke opvoeding

$\mathrm{HBO}$ lerarenopleiding medisch en verzorging

HBO lerarenopleiding expressie

$\mathrm{HBO}$ tolk en vertaler

HBO landbouw en veeteelt

HBO milieukunde en levensmiddelentechnologie

$\mathrm{HBO}$ laboratorium
$\%$

4,4

typering

\section{laag}

hoog

$\begin{array}{ll}3,6 & \text { laag } \\ 4,5 & \text { laag }\end{array}$

hoog

5,5

2,9

gemiddeld

erg laag

gemiddeld

gemiddeld

gemiddeld

gemiddeld

laag

gemiddeld

hoog

gemiddeld

erg hoog

hoog

gemiddeld

erg laag

gemiddeid

gemiddeld

gemiddeld

gemiddeld

laag

gemiddeld

laag

gemiddeld

gemiddeld

gemiddeld

hoog

laag

laag

gemiddeld

gemiddeld

erg hoog

laag

hoog

hoog

gemiddeld

hoog

hoog

laag

laag

laag

gemiddeld

gemiddeld

erg laag

gemiddeld

hoog

laag

hoog

gemiddeld

gemiddeld

gemiddeld

laag

erg hoog

erg laag

gemiddeld 
Tabel 3.9 (vervolg)

Verwachte baanopeningen per opleidingstype, Limburg. 2000 (percentage van de werkgelegenheid)

Opleidingstype

$\%$

typering

HBO bouwkunde

HBO civiele techniek

$\mathrm{HBO}$ werktuigbouwkunde

(1)

$\mathrm{HBO}$ elektrotechniek

$\mathrm{HBO}$ informatica

$\mathrm{HBO}$ chemische technologie

$H B O$ vervoer en logistiek

$H B O$ verpleegkunde

HBO (fysio)therapie

$H B O$ voeding

$\mathrm{HBO}$ accountancy en bedrijfseconomie

HBO commerciéle economie

$\mathrm{HBO}$ toerisme en recreatie

$\mathrm{HBO}$ recht en bestuur

$\mathrm{HBO}$ secretariaat

HBO bedrijfskunde

HBO communicatie en journalistiek

HBO maatschappelijk werk en hulpverlening

HBO personeel en arbeid

HBO bibliotheek en documentatie

$H B O$ uitvoerende en beeldende kunsten

$\mathrm{HBO}$ openbare orde en veiligheid

WO letteren

WO theologie

WO lanabouw en milieukunde

WO wiskunde en natuurwetenschappen

Wo bouwkunde

WO civiele techniek

WO werktuigbouwkunde

WO elektrotechniek

WO informatica en bestuurlijke informatiekunde

WO (dier)geneeskunde

WO tandheelkunde

WO farmacie

WO econom(etr)le

WO bedrifskunde

WO accountancy en belastıngen

WO rechten en bestuurskunde

WO sociale wetenschappen

WO kunstwetenschappen

laag

erg laag

gemiddeld

gemiddeld

erg hoog

hoog

laag

hoog

hoog

hoog

gemiddeld

gemiddeld

hoog

hoog

erg hoog

gemiddeld

erg hoog

laag

laag

erg hoog

gemiddeld

gemiddeld

gemiddeld

gemiddeld

erg laag

laag

gemiddeld

gemiddeld

erg laag

erg laag

erg hoog

laag

gemiddeld

erg laag

erg hoog

hoog

hoog

erg laag

gemiddeld

erg laag

Totaal

5,8

Bron ROA 
Tabel 3.10

Verwachte arbeidsmarktinstroom van schoolverlaters per opleidingstype, Limburg, 2000 (percentage van de werkgelegenheld)

$\begin{array}{lll}\text { Opleidingstype } & \% & \text { typering }\end{array}$

\author{
Basisonderwijs \\ VMBO theorie \\ VMBO landbouw en natuurlijke omgeving \\ VMBO bouwtechniek \\ VMBO installatietechniek \\ VMBO metaal: mechanische techniek \\ VMBO voertuigentechniek \\ VMBO elektrotechniek \\ VMBO grafische techniek \\ VMBO brood en banket \\ VMBO consumptief en levensmiddelentechniek \\ VMBO transport en logistiek \\ VMBO administratie, handel en mode \\ VMBO (uiterlijke) verzorging \\ VMBO beveiliging \\ HAVOMWO \\ MBO landbouw en veeteelt \\ MBO milieu en groene rumte \\ $M B O$ laboratorium \\ MBO bouw \\ MBO grond-, weg- en waterbouw \\ MBO installatietechniek \\ MBO werktuigbouw en mechanische techniek \\ MBO fijnmechanische techniek \\ MBO motorvoertuigentechniek \\ MBO vliegtuigtechniek \\ MBO operationele techniek \\ MBO elektrotechniek \\ MBO grafische techniek \\ MBO procestechniek \\ MBO brood en banket \\ MBO levensmiddelentechniek/vleesverwerking \\ $M B O$ vervoer en logistiek \\ MBO dokters-, tandarts- en dierenartsassistent \\ MBO apothekersassistent \\ $M B O$ verpleging \\ MBO gezondheidstechniek \\ MBO sociaal-cultureel \\ $M B O$ verzorging \\ MBO uiterlijke verzorgıng \\ MBO horeca \\ $M B O$ beweging en therapie \\ $M B O$ admınistratie \\ MBO handel \\ MBO secretariaat \\ MBO toerisme en recreatie \\ MBO openbare arde en veiligheid
}

Totaal
4,2

4,4

4,4

4,0

2.1

3,5

3,2

-

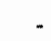

1.4

6.1

3,4

;

6.9
2.4

2.4

3,6

5,0

4,0

2,5

.

3,1

3,8

2.4

$=$

2.4

-

1.4

7,7

3,4

4,8

5,1

6.9

4.3

3.1

4.9

1,8

4,2 gemideld

gemiddeld

gemiddeld

gemiddeld

erg noog

laag

gemıddeld

gemiddeld

gemiddeld

gemiddeld

hoog

laag

noog

gemiddeld

erg hoog

hoog

laag

hoog

gemiddeld

gemiddeld

gemiddeld

gemiddeld

gemiddeld

laag

laag

laag

hoog

gemiddeld

gemiddeld

laag

gemiddeld

laag

laag

erg hoog

erg hoog

erg laag

erg laag

erg hoog

gemiddeld

gemiddeld

hoog

hoog

gemideld

gemiddeld

gemiddeld

noog

laag

Bron: ROA 
Tabel 3.11

Inolicator Toekomstige Arbeidsmarktperspectıeven (ITA) en Indicator Toekomstige Knelpunten in de Personeelsvoorziening (ITKP) naar opleiding, Limburg, 2000

\begin{tabular}{|c|c|c|c|c|}
\hline Opleidingstype & ITA & typering & ITKP & typering \\
\hline Basisonderwijs & 1.01 & redelijk & 1,03 & enige \\
\hline VMBO theorie & 0,99 & goed & 0,99 & groot \\
\hline VMBO landbouw en natuurlijke omgeving & 1,00 & redelijk & 1,05 & enige \\
\hline VMBO bouwtechniek & 0.93 & goed & 0,95 & groot \\
\hline VMBO installatietechniek & - & goed & - & enige \\
\hline VMBO metaal mechanische techniek & 0,97 & goed & 1,00 & entige \\
\hline VMBO voertuigentechniek & 1.01 & redelijk & 1,04 & enige \\
\hline VMBO elektrotechniek & 0,97 & goed & 0,97 & groot \\
\hline VMBO grafische techniek & - & goed & - & enige \\
\hline VMBO brood en banket & - & goed & $=$ & enige \\
\hline VMBO consumptief en levensmiddelentechnıek & - & redelijk & - & enige \\
\hline VMBO transport en logistiek & 0,76 & zeer goed & 0,78 & zeer groot \\
\hline VMBO administratie, handel en mode & 1,05 & matig & 1,08 & vrijwel geen \\
\hline VMBO (uiterlijke) verzorging & 0.97 & goed & 0,97 & groot \\
\hline VMBO beveiliging & - & goed & - & groot \\
\hline HAVONWO & 0,99 & goed & 0,99 & groot \\
\hline MBO landbouw en veeteelt & 0,95 & goed & 0,95 & groot \\
\hline MBO millieu en groene ruimte & - & goed & - & groot \\
\hline MBO laboratorium & - & redelijk & - & vrijwel geen \\
\hline MBO bouw & 0,99 & goed & 0.99 & groot \\
\hline MBO grond-, weg-en waterbouw & - & goed & - & groot \\
\hline MBO installatietechnık & 1.00 & redelijk & 1,00 & enige \\
\hline MBO werktuigbouw en mechanische techniek & 0,95 & goed & 0.95 & groot \\
\hline MBO fijninechanische techniek & 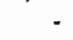 & goed & - & groot \\
\hline MBO motorvoertuigentechniek & 0.98 & goed & 0,98 & groot \\
\hline MBO vliegtuigtechniek & - & goed & - & groot \\
\hline MBO operationele techniek & - & redelijk & - & enige \\
\hline MBO elektrotechniek & 0.98 & goed & 0.98 & groot \\
\hline MBO grafische techniek & 0.99 & goed & 1,00 & enige \\
\hline MBO procestechniek & 0,96 & goed & 0.96 & groot \\
\hline MBO brood en banket & - & goed & - & enige \\
\hline MBO levensmiddelentechniek/vleesverwerking & - & goed & - & groot \\
\hline MBO vervoer en logistiek & 0,98 & goed & 0,98 & groot \\
\hline MBO dokters-, tandarts-en dierenartsassistent & " & redelijk & . & enige \\
\hline MBO apothekersassistent & - & goed & - & groot \\
\hline MBO verpleging & 0,97 & goed & 0,97 & groot \\
\hline MBO gezondheidstechniek & - & goed & - & groot \\
\hline MBO sociaal-cultureel & 0.94 & goed & 0.94 & groot \\
\hline MBO verzorging & 0.98 & goed & 0,98 & groot \\
\hline MBO uiterlijke verzorging & 0.98 & goed & 0,98 & groot \\
\hline MBO horeca & 0.97 & goed & 0,97 & groot \\
\hline MBO beweging en therapie & 1.04 & redelijk & 1,04 & enige \\
\hline MBO administratie & 1,00 & redelijk & 1.00 & enige \\
\hline MBO handel & 0.92 & goed & 0.92 & groot \\
\hline MBO secretariaat & 0.98 & gloed & 0.98 & groot \\
\hline MBO toerisme en recreatie & + & goed & - & groot \\
\hline MBO openbare orde en veiligheid & 0,99 & goed & 0.99 & groot \\
\hline
\end{tabular}

Bron: ROA 
Tabel 4.1

Verwachte uitbreidingsvraag per bedrifssector. Limburg, 1999-2004 (percentage van de werkgelegenheid)

\begin{tabular}{lcl} 
Bedrijfssector & $\%$ & typering \\
\hline Landbouw en visserij & 4 & gemiddeld \\
Voeding & 3 & gemiddeld \\
Chemie & -4 & erg laag \\
Metaal en elektrotechniek & -3 & erg laag \\
Overige industrie & -2 & erg laag \\
Energie & -3 & erg laag \\
Bouw en onroerend goed & -3 & erg laag \\
Handel & 4 & gemiddeld \\
Transport en communicatie & 0 & erg laag \\
Bank en verzekeringswezen & -1 & erg laag \\
Horeca. reparatie en zakelijke dienstverlening & 16 & erg hoog \\
Kwartaire diensten & 6 & gemiddeld \\
Overheid en onderwijs & -2 & erg laag \\
Totaal & 3 & \\
\hline
\end{tabular}

Bron: ROATNO/Inro 
Tabel 42

Verwachte uitbreidingsvraag per beroepsgroep. Limburg. 1999-2004 (percentage van de werkgelegenheid)

Beroepsgroep

$\%$

typering

Leraar basisonderwijs

Docenten exacte, medische en verzorgende vakken ( 2 e graads)

1

Docenten exacte, medische en verzorgende vakken (1e graads)

Docenten landbouw en techniek (2e graads)

Docenten economisch-administratieve vakken (2e graads)

Docenten economisch-administratieve vakken (1e graads)

Docenten talen en expressie

Docenten letteren (1e graads)

Docenten sociale vakken (2e graads)

Docenten sociale vakken (1e graads)

Docenten ze graads zonder specialisatie

Onderwijskundig medewerkers

Onderwijskundigen en pedagogen

Rij-instructeurs

Zweminstructeurs

Sportinstructeurs

Tolken, vertalers en schrijvers

Bibliotheekassistenten

Bibliothecarissen

Grafisch ontwerpers

Kunstenaars

Geestelijken

Journalisten

Taalkundigen

Agrarische hulparbeiders

Agrarische arbeiders

Agrarische vakkrachten

Milieuhygienısten en agrarisch vertegenwoordigers

Landbouwmachinebestuurders en vissers

Agrarische bedrijfshoofden

Productiemedewerkers

Laboranten

Technisch analisten

Natuurwetenschappers

Concierges

Hoofden technische dienst

Werktuigbouwkundigen

Bouwvakkers

Aannemers en installateurs

Architecten en bouwkundig projectleiders

Weg- en waterbouwkundigen

Weg-en waterbouwkundige arbeiders

Weg-en waterbouwkundige vakkrachten

Weg-en waterbouwkundig ontwerpers en projectleiders

Metaalarbeiders

Bankwerkers en lassers

Bedrijfshoofden metaalbewerking

Assembleurs

Monteurs

Werktuigbouwkundig ontwerpers en hoofden technische dienst

Elektronicamonteurs

Monteurs en controleurs elektrotechnische producten

Elektromonteurs

Elektrotechnisch ontwerpers en bedrijfshoofden

Elektrotechnici

Grafisch productiepersoneel

Grafische vakkrachten

Mechanisch operators

gemiddeld

laag

gemiddeld

gemiddeld

laag

gemiddeld

laag

gemiddeld

laag

gemiddeld

gemiddeld

hoog

hoog

gemiddeld

gemiddeld

gemiddeld

gemiddeld

laag

gemiddeld

gemiddeld

gemidideld

noog

gemiddeld

gemiddeld

gemiddeld

laag

gemiddeld

laag

laag

gemiddeld

gemiddeld

erg laag

erg laag

laag

erg laag

laag

erg laag

erg laag

laag

laag

erg laag

erg laag

laag

erg laag

erg laag

laag

laag

erg laag

erg laag

erg laag

laag

erg laag

laag

erg laag

erg laag

erg laag

laag

erg laag 


$\begin{array}{lll}\text { Beroepsgroep } & \% & \text { typering }\end{array}$

Procesoperators

Procestechnologen

Materiaalkundigen

Confectie-arbeiders

Schoen-en kleermakers

Laders en lossers

Chauffeurs

Schippers en conducteurs

Vhegers, scheepskapiteins en leidinggevenden transport

Stewards

Verpleeghulpen en leerling-verpleegkundigen

Verplegenden en doktersassistenten

Therapeuten en verpleegkundigen

Artsen

Apothekersassistenten en medisch laboranten

Medisch analisten

Apothekers

Afdelingshoofden zorginstelling

Kantoorhulpen, inpakkers en colporteurs

Ondersteunende administratieve hulpkrachten

Bedrijfshoofden

Economen

Productieplanners

Organısatie-adviseurs

Organisatiedeskundigen

Receptionisten en administratieve employés

Boekhouders en secretaresses

Assistent accountants

Accountants

Verzekeringsagenten

Commercieel employés

Commercieel medewerkers

Technisch-commercieel employés

Technisch-bedrijfskundig medewerkers

Juridisch en fiscaal medewerkers

Juridisch, bestuurlijk medewerkers

Juristen

Administratieve transportemployes

Leidinggevenden

Managers

Medisch secretaresses

Programmeurs

Systeemanalisten

- $\quad$ erg laag

- $\quad$ erg laag

-32 erg laag

Informatici

Technisch systeemanalisten

Activiteitenbegeleiders en medewerkers arbeidsbemiddeling

laag

gemiddeld

hoog

gemıddeld

gemiddeld

gemiddeld

gemiddeld

gemiddeld

gemiddeld

gemiddeld

gemiddeld

gemiddeld

laag

erg hoog

laag

erg hoog

erg hoog

hoog

erg hoog

gemiddeld

erg hoog

hoog

erg hoog

gemiddeld

erg hoog

gemiddeld

hoog

gemiddeld

gemıddeld

gemiddeld

laag

germiddeld

gemiddeld

hoog

gemiddeld

erg hoog

gemiddeld

erg laag

Medewerkers sociaal-cultureel werk en personeel en arbeid

hoog

gemiddeld

hoog

Hoofden sociaal-cultureel werk en personeel en arbeid

gemiddeld

hoog

Sociaal-wetenschappelijk onderzoekers

Interieurverzorgers

gemiddeld

Verkopers

erg hoog

Winkeliers -10

Hulpkrachten horeca en verzorging $\quad-12$

Ziekenverzorgenden

gemiddeld

laag

erg hoog

gemiddeld

laag

Café- en snackbarhouders

Bedrijfshoofden horeca

gemiddeld 
Tabel 4.2 (vervolg)

Verwachte uitbreidingsvraag per beroepsgroep, Limburg, 1999-2004 (percentage van de werkgielegenheid)

$\begin{array}{lll}\text { Beroepsgroep } & \% & \text { typering }\end{array}$

Bakkers en slagers

Aspirant politieagenten, soldaten en beveiligingshulpkrachten

Politieagenten. onderofficieren en beveiligingsemployes

erg laag

Politie-inspecteurs en officieren

Brandweerlieden

gemiddeld

gemiddeld

gemiddeld

Totaal

laag

3

Bron ROA 
Tabel 4.3

Verwachte vervangingsvraag per beroepsgroep, Limburg, $1999-2004$ (percentage van de werkgelegenheid)

\section{Beroepsgroep}

Leraar basisonderwijs

Docenten exacte, medische en verzorgende vakken (2e graads)

Docenten exacte, medische en verzorgende vakken (1e graads)

Docenten landbouw en techniek (2e graads)

Docenten economisch-administratieve vakken (2e graads)

Docenten economisch-administratieve vakken (1e graads)

Docenten talen en expressie

Docenten letteren (1e graads)

Docenten sociale vakken (2e graads)

Docenten sociale vakken (1e graads)

Docenten 2e graads zonder specialisatie

Onderwijskundig medewerkers

Onderwijskundigen en pedagogen

Rij-instructeurs

Zweminstructeurs

Sportinstructeurs

Tolken, vertalers en schrijvers

Bibliotheekassistenten

Bibliothecarissen

Grafisch ontwerpers

Kunstenaars

Geestelijken

Journalisten

Taalkundigen

Agrarische hulparbeiders

Agrarische arbeiders

Agrarische vakkrachten

Milieuhygiënisten en agrarisch vertegenwoordigers

Landbouwmachinebestuurders en vissers

Agrarische bedrijfshoofden

Productiemedewerkers

Laboranten

Technisch analisten

Natuurwetenschappers

Cancierges

Hoofden technische dienst

Werktuigbouwkundigen

Bouwvakkers

Aannemers en installateurs

Architecten en bouwkundig projectleiders

Weg-en waterbouwkundigen

Weg-en waterbouwkundige arbeiders

Weg-en waterbouwkundige vakkrachten

Weg- en waterbouwkundig ontwerpers en projectleiders

Metaalarbeiders

Bankwerkers en lassers

Bedrijfshoofden metaalbewerking

Assembleurs

Monteurs

Werktuigbouwkundig ontwerpers en hoofden technische dienst

Elektronicamonteurs

Monteurs en controleurs elektrotechnische producten

Elektromonteurs

Elektrotechnisch ontwerpers en bedrijfshoofden

Elektrotechnici

Grafisch productiepersoneel

Grafische vakkrachten

Mechanisch operators

typering

19

-

$-$

30

$-$

$-$

$-$

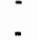

$-$

-

$-$

$-$

$-$

$-$

$-$

$-$

-

-

- gemiddeld

hoog

hoog

erg hoog

hoog

gemiddeld

hoog

hoog

hoog

hoog

hoog

hoog

gemiddeld

hoog

gemiddeld

gemiddeld

gemiddeld

gemiddeld

hoog

erg laag

gemiddeld

gemiddeld

laag

gemiddeld

laag

gemiddeid

laag

gemiddeld

gemiddeld

gemiddeld

laag

gemiddeld

gemiddeld

gemiddeld

hoog

gemiddeld

gemiddeld

gemiddeld

gemiddeld

gemiddelo

hoog

gemiddeld

gemiddeid

laag

germiddeld

gemiddeld

hoog

gemiddeid

gemiddeld

hoog

gemiddeld

gemiddeld

gemiddeld

hoog

laag

gemiddeld

gemiddeld

gemiddeld 
Tabel 4.3 (vervolg)

Verwachte vervangingsvraag per beroepsgroep, Limburg, 1999-2004 (percentage van de werkgelegenheid)

Beroepsgroep

$\%$

Procesoperators

Procestechnologen

Materiaalkundigen

Confectie-arbeiders

Schoen-en kleermakers

Laders en lossers

Chauffeurs

Schippers en conducteurs

Vliegers, scheepskapiteins en leidinggevenden transport

Stewards

Verpleeghulpen en leerling-verpleegkwndigen

Verplegenden en doktersassistenten

Therapeuten en verpleegkundigen

Artsen

Apothekersassistenten en medisch laboranten

Medisch analisten

Apothekers

Afdelingshoofden zorginstelling

Kantoorhulpen, inpakkers en colporteurs

Ondersteunende administratieve hulpkrachten

Bedrijfshoofden

Economen

Productieplanners

Organisatie-adviseurs

Organisatiedeskundigen

Receptionisten en administratieve employes

Boekhouders en secretaresses

Assistent accountants

Accountants

Verzekeringsagenten

Commercieel employés

Commercieel medewerkers

Technisch-commercieel employes

Technisch-bedriffskundig medewerkers

Juridisch en fiscaal medewerkers

Juridisch, bestuurlijk medewerkers

Juristen

Administratieve transportemployés

Lerdinggevenden

Managers

Medisch secretaresses

Programmeurs

Systeemanalisten

Informatici

Technisch systeemanalisten

Activiteitenbegeleiders en medewerkers arbeidsbemiddeling

Medewerkers sociaal-cultureel werk en personeel en arbeid

Hoofden sociaal-cultureel werk en personeel en arbeid

Sociaal-wetenschappelijk medewerkers

Sociaal-wetenschappelijk onderzoekers

Interieurverzorgers

Verkopers

Winkeliers

Hulpkrachten horeca en verzorging

Ziekenverzorgenden

Verzorgend personeel

Café- en snackbarhouders

Bedrijfshoofden horeca
14

-

25

$-$

11

17

.

-

?

22

20

15

19

-

-

-

11

-

$-$ typering

laag

hoog

gemiddeld

hoog

hoog

erg laag

gemiddeld

gemiddeld

laag

laag

laag

hoog

gemiddeld

gemiddeld

gemiddeld

gemiddeld

laag

erg hoog

erg laag

hoog

gemiddeld

laag

erg laag

erg laag

laag

hoog

laag

laag

laag

gemiddeld

laag

laag

gemiddeld

gemiddeld

gemiddeld

hoog

laag

gemiddeld

gemiddeld

gemiddeld

gemiddeld

erg laag

erg laag

erg laag

erg laag

erg laag

gemiddeld gemiddeld

hoog

laag

gemiddeld gemiddeld gemiddeld hoog

laag

gemiddeld

hoog

gemiddeld 
Tabel 4.3 (vervolg)

Verwachte vervangingsvraag per beroepsgroep, Limburg, 1999-2004 (percentage van de werkgelegenheid)

Beroepsgroep

Bakkers en slagers

Aspirant politieagenten, soldaten en beveiligingshulpkrachten

Politieagenten, onderofficieren en beveiligingsemployes

Politie-inspecteurs en officieren

Brandweerlieden

Totaal

Bron: ROA
$\% \quad$ typering

gemiddeld

gemiddeld

gemiddeld laag

hoog

15

18

- hoog


Verwachte baanopeningen per beroepsgroep, Limburg, 1999-2004 (percentage van de werkgetegenheid)

$\%$

20

Leraar basisonderwijs

Docenten exacte, medische en verzorgende vakken (2e graads)

Docenten exacte, medische en verzorgende vakken (1e graads)

Docenten landbouw en techniek (2e graads)

Docenten economisch-administratieve vakken (2e graads)

Docenten economisch-administratieve vakken (1e graads)

Docenten talen en expressie

Docenten letteren (1e graads)

Docenten sociale vakken (2e graads)

Docenten sociale vakken (1e graads)

Docenten $2 \mathrm{e}$ graads zonder specialisatie

Onderwijskundig medewerkers

Onderwijskundigen en pedagogen

Rii-instructeurs

Zweminstructeurs

Sportinstructeurs

Tolken, vertalers en schrijvers

Bibliotheekassistenten

Bibliothecarissen

Grafisch ontwerpers

Kunstenaars

Geestelijken

Journalisten

Taalkundigen

Agrarische hulparbeiders

Agrarische arbeiders

Agrarische vakkrachten

Milieuhygienisten en agrarisch vertegenwoordigers

Landbouwmachinebestuurders en vissers

Agrarische bedrijfshoofden

Productiemedewerkers

Laboranten

Technisch analisten

Natuurwetenschappers

Concierres

Hoofden technische dienst

Werktuigbouwkundigen

Bouwvakkers

Aannemers en installateurs

Architecten en bouwkundig projectleiders

Weg- en waterbouwkundigen

Weg- en waterbouwkundige arbeiders

Weg-en waterbouwkundige vakkrachten

Weg-en waterbouwkundig ontwerpers en projectleiders

Metaalarbeiders

Bankwerkers en lassers

Bedriffshoofden metaalbewerking

Assembleurs

Monteurs

Werktuigbouwkundig ontwerpers en hoofden technische dienst

Elektronicamonteurs

Monteurs en controleurs elektrotechnische producten

Elektromonteurs

Elektrotechnisch ontwerpers en bedrijfshoofden

Elektrotechnici

Grafisch productiepersoneel

Grafische vakkrachten

Mechanisch operators typering

gemiddeld

gemiddeld

gemiddeld

hoog

gemiddeld

gemiddeld

gemıddeld

gemiddeld

gemiddeld

gemiddeld

gemiddeld

hoog

gemiddeld

gemiddeld

gemiddeld

gemiadeld

gemiddeld

gemiddeld

gemiddeld

laag

gemiddeld

gemiddeld

laag

gemiddeld

laag

gemiddeld

laag

gemiddeld

gemiddeld

gemiddeld

laag

gemiadeld

gemiddeld

gemiddeld

gemiddeld

gemiddeld

gemiddeld

gemiddeld

gemiddeld

gemiddeld

gemiddeld

gemiddeld

gemiddeld

laag

gemiddeld

gemiddeld

gemiddeld

gemiddeld

gemiddeld

gemiddeld

gemiddeld

gemiddeld

gemiddeld

gemiddeld

laag

gemiddeld

gemiddeld

gemiddeld 


Beroepsgroep $\quad \% \quad$ typenng

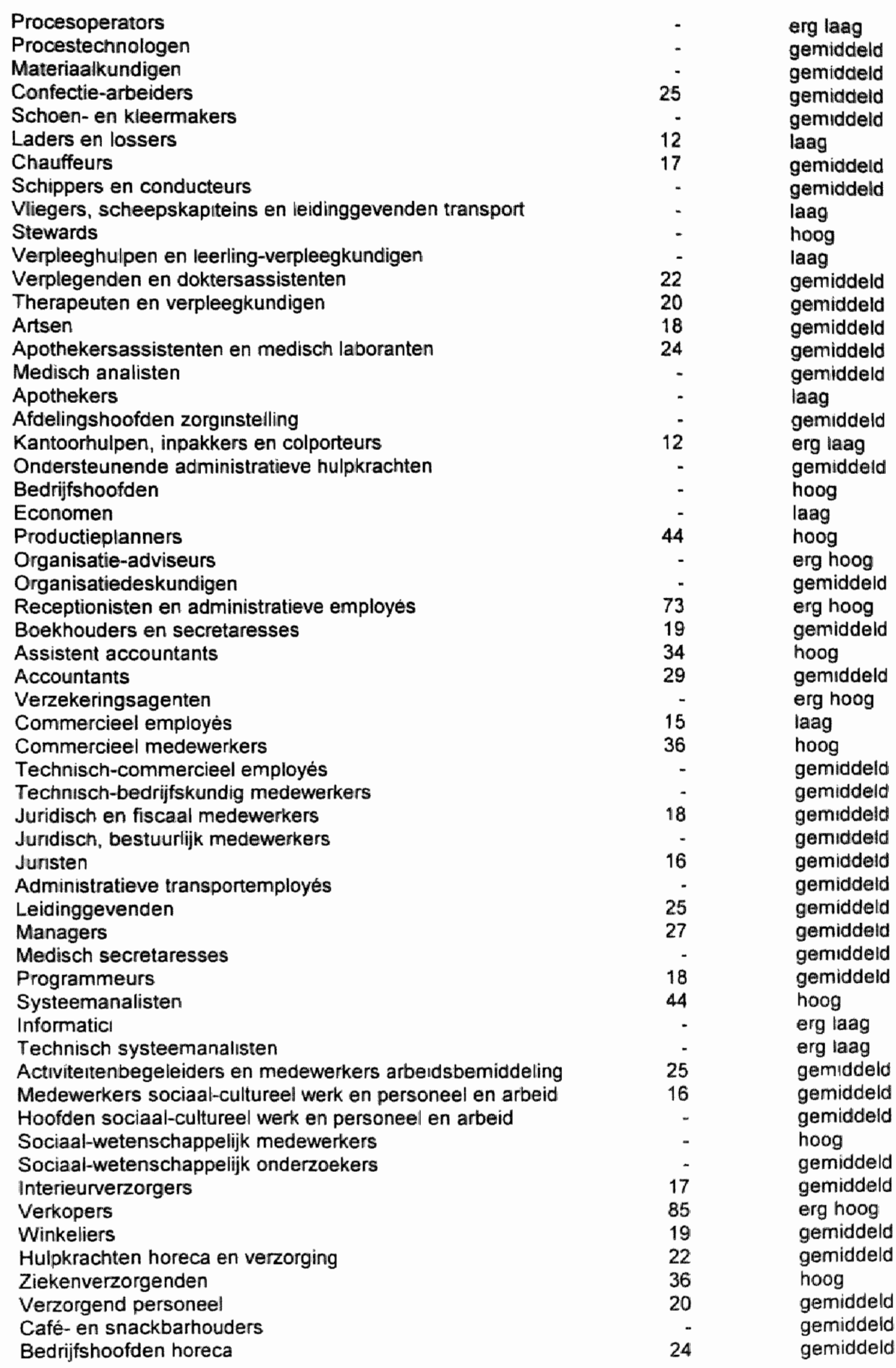


Tabel 4.4 (vervolg)

Verwachte baanopeningen per beroepsgroep. Limburg. 1999-2004 (percentage van de werkgelegenheid)

Beroepsgroep

Bakkers en slagers

Aspirant politteagenten, soldaten en beveiligingshulpkrachten

Politieagenten, onderofficieren en beveiligingsemployés

Politie-inspecteurs en officieren

Brandweerlieden

Totaal

Bron: ROA typering

erg laag

gemiddeld gemiddeld

laag

gemiddeld
15

18. 
Tabel 4.5

Verwachte uitbreidingsvraag per opleidingstype, Limburg. 1999-2004 (percentage van de werkgelegenheid)

\begin{tabular}{|c|c|c|}
\hline Oplerdingstype & $\%$ & typering \\
\hline Basisonderwijs & -21 & erg laag \\
\hline VMBO theorie & 8 & gemiddeld \\
\hline VMBO landbouw en natuurlijke omgeving & -26 & erg laag \\
\hline VMBO bouwtechniek & -21 & erg laag \\
\hline VMBO installatietechniek & - & erg laag \\
\hline VMBO metaal: mechanische techniek & -30 & eng laag \\
\hline VMBO voertuigentechniek & -27 & eng laag \\
\hline VMBO elektrotechniek & -16 & eng laag \\
\hline VMBO grafische techniek & $\cdot$ & erg laag \\
\hline VMBO brood en banket & - & erg laag \\
\hline VMBO consumptief en levensmiddelentechniek & $\cdot$ & laag \\
\hline VMBO transport en logistiek & -19 & erg laag \\
\hline VMBO administratie, handel en mode & -5 & laag \\
\hline VMBO (uiterlijke) verzorging & 6 & gemiddeld \\
\hline VMBO beveiliging & - & hoog \\
\hline HAVOMWO & 17 & gemiddeld \\
\hline MBO landbouw en veeteelt & 11 & gemiddeld \\
\hline MBO milieu en groene ruimte & - & hoog \\
\hline MBO laboratorium & - & erg laag \\
\hline MBO bouw & -2 & laag \\
\hline MBO grond-, weg-en waterbouw & - & laag \\
\hline MBO installatietechniek & -9 & laag \\
\hline MBO werktuigbouw en mechanische techniek & -15 & laag \\
\hline MBO fijnmechanische techniek & - & laag \\
\hline MBO motorvoertuigentechniek & -6 & laag \\
\hline MBO vliegtuigtechniek & - & erg laag \\
\hline MBO operationele techniek & - & gemiddeld \\
\hline MBO elektrotechniek & -6 & laag \\
\hline MBO grafische techniek & -23 & erg laag \\
\hline MBO procestechniek & 5 & gemiddeld \\
\hline MBO brood en banket & - & erg laag \\
\hline MBO levensmiddelentechniek/vleesverwerking & - & laag \\
\hline MBO vervoer en logistiek & 8 & gemiddeld \\
\hline MBO dokters- tandarts- en dierenartsassistent & - & gemiadeld \\
\hline MBO apothekersassistent & - & hoog \\
\hline MBO verpleging & 4 & gemiddeld \\
\hline MBO gezondheidstechniek & - & hoog \\
\hline MBO sociaal-cultureel & 19 & gemiddeld \\
\hline MBO verzorging & 0 & laag \\
\hline MBO uiterlijke verzorging & 17 & gemiddeld \\
\hline MBO horeca & 16 & gemiddeld \\
\hline MBO beweging en therapie & 2 & gemiddeld \\
\hline $\mathrm{MBO}$ administratie & 8 & gemiddeld \\
\hline MBO handel & 4 & gemiddeld \\
\hline MBO secretariaat & 18 & gemiddeld \\
\hline MBO toerisme en recreatie & - & hoog \\
\hline MBO openbare orde en veiligheid & -3 & laag \\
\hline HBO lerarenopleiding basisonderwijs & 8 & gemiddeld \\
\hline HBO lerarenopleiding talen & -17 & erg laag \\
\hline HBO lerarenopleiding natuur en techniek & -3 & laag \\
\hline HBO lerarenopleiding economie en maatschappij & 11 & gemiddeld \\
\hline HBO lerarenopleiding lichamelijke opvoeding & - & laag \\
\hline HBO lerarenopleiding medisch en verzorging & - & laag \\
\hline HBO lerarenopleiding expressie & -6 & laag \\
\hline HBO tolk en vertaler & - & gemiddeld \\
\hline HBO landbouw en veeteelt & . & erg hoog \\
\hline HBO milieukunde en levensmiddelentechnologie & - & gemiddeld \\
\hline HBO laboratorium & -7 & laag \\
\hline
\end{tabular}


Tabel 4.5 (vervolg)

Verwachte uitbreidingsvraag per opleidingstype, Limburg. 1999-2004 (percentage van de werkgelegenheid)

Opleidingstype

$\% \quad$ typering

HBO bouwkunde

gemiddeld

HBO civiele techniek

laag

HBO werktuigbouwkunde

gemiddeld

$\mathrm{HBO}$ elektrotechniek

gemiddeld

$\mathrm{HBO}$ informatica

$\mathrm{HBO}$ chemische technologie

erg hoog

$H B O$ vervoer en logistiek

$\mathrm{HBO}$ verpleegkunde

gemiddeld

gemiddeld

gemiddeld

HBO (fysio)therapie

gemiddeld

$\mathrm{HBO}$ voeding

$H B O$ accountancy en bedriffseconomie

noog

gemiddeld

$\mathrm{HBO}$ commerciele economie

hoog

$\mathrm{HBO}$ toerisme en recreatie

noog

$\mathrm{HBO}$ recht en bestuur

$\mathrm{HBO}$ secretariaat

hoog

gemiddeld

HBO bedrijfskunde

hoog

HBO communicatle en journalistiek

erg hoog

HBO maatschappelijk werk en hulpverlening

gemiddeld

HBO personeel en arbeid

$\mathrm{HBO}$ bibliotheek en documentatie

HBO uitvoerende en beeldende kunsten

gemiddeld

hoog

$\mathrm{HBO}$ openbare orde en veiligheid

WO letteren

WO theologie

WO landbouw en millieukunde

WO wiskunde en natuurwetenschappen

WO bouwkunde

WO civiele techniek

WO werktuigbouwkunde

WO elektrotechniek

WO informatica en bestuurlijke informatiekunde

WO (dier)geneeskunde

WO tandheelkunde

WO farmacie

WO econom(etr)ie

WO bedrijfskunde

WO accountancy en belastingen

WO rechten en bestuurskunde

WO sociale wetenschappen

gemiddeld

gemiddeld

gemiddeld

laag

gemiddeld

laag

erg laag

laag

laag

gemiddeld

erg hoog

laag

gemiddeld

gemiddeld

erg hoog

erg hoog

hoog

gemiddeld

WO kunstwetenschappen

gemıddeld

gemiddeld

Totaal

Bron: ROA 


Opleidingstype $\quad \% \quad$ typering

Basisonderwijs

VMBO theorie

VMBO landbouw en natuurlijke omgeving

VMBO bouwtechniek

VMBO installatietechniek

VMBO metaal: mechanische techniek

VMBO voertuigentechniek

VMBO elektrotechniek

VMBO grafische techniek

VMBO brood en banket

VMBO consumptief en levensmiddelentechniek

VMBO transport en logistiek

VMBO administratie, handel en mode

VMBO (uiterlijke) verzorging

VMBO beveiliging

HAVONWO

MBO landbouw en veeteelt

MBO milieu en groene ruimte

$M B O$ laboratorium

MBO bouw

MBO grond-. weg-en waterbouw

MBO installatietechniek

$M B O$ werktuigbouw en mechanische techniek

MBO fijnmechanische techniek

MBO motorvoertuigentechniek

MBO vliegtuigtechniek

MBO operationele techniek

MBO elektrotechniek

MBO grafische techniek

MBO procestechniek

$\mathrm{MBO}$ brood en banket

MBO levensmiddelentechniek/vleesverwerking

MBO venver en logistiek

MBO diokters-, tandarts- en dierenartsassıstent

MBO apothekersassistent

MBO verpleging

MBO gezondheidstechniek

MBO sociaal-cultureel

$M B O$ verzorging

MBO uiterlijke verzorging

MBO horeca

MBO beweging en therapie

MBO administratie

MBO handel

MBO secretariaat

MBO toerisme en recreatie

MBO openbare orde en veiligheid

HBO lerarenopleiding basisonderwijs

$\mathrm{HBO}$ lerarenopleiding talen

HBO lerarenopleiding natuur en techniek

$\mathrm{HBO}$ lerarenopleiding economie en maatschappij

HBO lerarenopleiding lichamelijke opvoeding

$\mathrm{HBO}$ lerarenopleiding medisch en verzorging

$\mathrm{HBO}$ lerarenopleiding expressie

$\mathrm{HBO}$ tolk en vertaler

$\mathrm{HBO}$ landbouw en veeteelt

HBO milieukunde en levensmiddelentechnologie

HBO laboratorium gemiddeld

hoog

gemiddeld

gemiddeld

erg hoog

hoog

laag

erg hoog

erg hoog

hoog

hoog

gemiddeld

hoog

erg hoog

gemiddeld

erg hoog

gemiddeld

laag

gemiddeld

laag

hoog

laag

hoog

gemiddeld

laag

gemiddeld

laag

gemiddeld

hoog

erg laag

gemiddeld

gemiddeld

gemiddeld

laag

erg hoog

gemiddeld

laag

gemiddeid

noog

gemiddeld

laag

gemiddeld

gemiddela

gemiddeld

gemiddeld

erg laag

laag

hoog

erg hoog

gemiddeld

hoog

hoog

hoog

erg hoog

erg laag

laag

laag

hoog 
Tabel 4.6 (vervolg)

Verwachte vervangingsvraag per opleidingstype, Limburg. 1999-2004 (percentage van de werkgelegenheid)

$\%$

HBO bouwkunde

$\mathrm{HBO}$ civiele techniek

$\mathrm{HBO}$ werkturgbouwkunde

HBO elektrotechniek

$\mathrm{HBO}$ informatica

$\mathrm{HBO}$ chemische technologie

$H B O$ venoer en logistiek

$\mathrm{HBO}$ verpleegkunde

$\mathrm{HBO}$ (fysio)theraple

$H B O$ voeding

HBO accountancy en bedriffseconomie

$\mathrm{HBO}$ commerciele economie

$\mathrm{HBO}$ toerisme en recreatie

$\mathrm{HBO}$ recht en bestuur

HBO secretariaat

HBO bedriffskunde

HBO communicatie en journalistiek

HBO maatschappelijk werk en hulpverlening

HBO personeel en arbeid

HBO bibliotheek en documentatie

HBO uitvoerende en beeldende kunsten

$\mathrm{HBO}$ openbare orde en veiligheid

WO letteren

WO theologie

WO landbouw en milieukunde

WO wiskunde en natuurwetenschappen

WO bouwkunde

WO civiele techniek

WO werkturgbouwkunde

WO elektrotechniek

WO informatica en bestuurlijke informatiekunde

WO (dier)geneeskunde

WO tandheeikunde

WO farmacie

WO econom(etr)ie

WO bedriffskunde

WO accountancy en belastingen

WO rechten en bestuurskunde

WO sociale wetenschappen

WO kunstwetenschappen typering

gemiddeld

gemiddeld

hoog

gemiddeld

gemiddeld

erg hoog

gemiddeld

gemiddeld

laag

gemiddeld

gemiddeld

laag

laag

laag

erg hoog

erg laag

erg laag

gemiddeld

gemiddeld

hoog

gemiddeld

hoog

laag

hoog

erg laag

gemiddeld

gemiddeld

hoog

erg laag

laag

erg laag

gemiddeld

gemiddeld

erg laag

laag

erg laag

gemiddeld

gemiddeld

gemiddeld

erg laag

Totaal

Bron: ROA 


$\begin{array}{lll}\text { Opleidingstype } & \% & \text { typering }\end{array}$

Basisonderwijs
VMBO theorie
VMBO landbouw en natuurlijke omgeving
VMBO bouwtechniek
VMBO installatietechniek
VMBO metaal: mechanische techniek
VMBO voertuigentechniek
VMBO elektrotechniek
VMBO grafische techniek
VMBO brood en banket
VMBO consumptief en levensmiddelentechniek
VMBO transport en logistiek
VMBO administratte, handel en mode
VMBO (uiterlijke) verzorging
VMBO beveiliging
HAVONWO
MBO landbouw en veeteelt
MBO milieu en groene ruimte
MBO laboratorium
MBO bouw

MBO grond-, weg- en waterbouw

MBO installatietechniek

MBO werktuigbouw en mechanische techniek

MBO fijnmechanische techniek

MBO motorvoertuigentechniek

MBO vliegtuigtechniek

MBO operationele techniek

MBO elektrotechniek

MBO grafische techniek

MBO procestechniek

MBO brood en banket

MBO levensmiddelentechniek/vieeswerwerking

$M B O$ vervoer en logistiek

MBO dokters-, tandlarts- en dierenartsassistent

MBO apothekersassistent

$M B O$ verpleging

MBO gezondheidstechniek

MBO sociaal-cultureel

$M B O$ verzorging

$M B O$ uiterlijke verzorging

MBO horeca

MBO beweging en therapie

MBO administratie

MBO handel

MBO secretariaat

MBO toerisme en recreatie

MBO openbare orde en veiligheid

HBO lerarenopleiding basisonderwijs

HBO lerarenopleiding talen

$\mathrm{HBO}$ lerarenopleiding natuur en techniek

$\mathrm{HBO}$ lerarenopleiding economie en maatschappij

HBO lerarenopleiding lichamelijke opvoeding

$\mathrm{HBO}$ lerarenopleiding medisch en verzorging

HBO lerarenopleiding expressie

$\mathrm{HBO}$ tolk en vertaler

$\mathrm{HBO}$ landbouw en veeteelt

HBO milieukunde en levensmiddelentechnologie

HBO laboratorium
22

36

18

22

27

14

31 laag

hoog

laag

laag

hoog

gemiddeld

erg laag

gemiddeld

gemiddeld

gemıddeld

gemiddeld

laag

gemiddeld

hoog

hoog

erg hoog

gemiddeld

hoog

laag

erg laag

gemiddeld

erg laag

gemiddeld

laag

erg laag

laag

laag

erg laag

gemiddeld

erg laag

laag

laag

gemiddeld gemiddeld

erg hoog

laag gemiddeld hoog

gemiddeld hoog

gemiddela gemiddeld gemiddeld gemiddeld hoog

hoog

erg laag

gemiddeld gemiddeld laag

hoog gemiddeld gemiddeld gemiddeld gemiddeld org hoog gerniddeld gemiddeld 
HBO bouwkunde

HBO civiele techniek

HBO werkturgbouwkunde
HBO elektrotechniek

laag

laag

HBO informatica

HBO chemische technologie

$H B O$ vervoer en logistiek

$\mathrm{HBO}$ verpleegkunde

gemiddeld

gemiddeld

HBO (fysio)therapie

erg hoog

$H B O$ voeding

HBO accountancy en bedriffseconomie

$\mathrm{HBO}$ commerciële economie

HBO toerisme en recreatie

$\mathrm{HBO}$ recht en bestuur

HBO secretariaat

$\mathrm{HBO}$ bedrijfskunde

HBO communicatie en journalistiek

HBO maatschappelijk werk en hulpverlening

hoog

gemiddeld

36

31

hoog

gemiddeld

hoog

39

hoog

hoog

hoog

hoog

hoog

HBO personeel en arbeid

$\mathrm{HBO}$ bibliotheek en documentatie

$H B O$ uitvoerende en beeldende kunsten

erg hoog

29

gemiddeld

gemiddeld

$\mathrm{HBO}$ apenbare orde en veiligheid

WO letteren

Wo theologie

WO landbouw en milieukunde

WO wiskunde en natuurwetenschappen

WO bouwkunde

WO civiele techniek

WO werktuigbouwkunde

WO elektrotechniek

WO informatica en bestuurlijke informatiekunde

WO (dier)geneeskunde

WO tandheelkunde

Wo farmacie

WO econom(etr)ie

WO bedrijtskunde

WO accountancy en belastingen

WO rechten en bestuurskunde

erg hoog

25

gemiddeld

gemiddeld

gemiddeld

gemiddeld

laag

laag

laag

laag

erg laag

gemiddeld

erg hoog

WO sociale wetenschappen

WO kunstwetenschappen

laag

gemiddeld

erg laag

erg hoog

erg hoog

erg hoog

laag

gemiddeld

erg laag

Totaal

29

Bron ROA 
Tabel 4.8

Verwachte arbeidsmarktinstroom van schoolverlaters per opleidingstype, Limburg, 1999-2004 (percentage van de werkgelegenheid)

$\begin{array}{lll}\text { Opleidingstype } & \% & \text { typering }\end{array}$

Basisonderwijs

VMBO theorie 24

VMBO landbouw en natuurtijke omgeving 24

VMBO bouwtechniek 22

VMBO installatietechniek

VMBO metaal: mechanische techniek

VMBO voertuigentechniek 19

VMBO elektrotechniek $\quad 17$

VMBO grafische techniek

VMBO brood en banket

VMBO consumptief en levensmiddelentechniek

VMBO transport en logistiek

VMBO administratie, handel en mode

VMBO (uiterlijke) verzorging

gemiddeld

VMBO beveiliging

HAVONWO

$M B O$ landbouw en veeteelt

MBO milieu en groene ruimte

MBO laboratorium

MBO bouw

MBO grond-, weg- en waterbouw

MBO installatietechniek

MBO werktuigbouw en mechanische techniek

MBO fijnmechanische techniek

MBO motorvoertuigentechniek

$M B O$ vliegtuigtechniek

MBO operationele techniek

MBO elektrotechniek

MBO grafische techniek

gerniddeld

gemiddeld

gemiddeld

erg hoog

laag

gemiddeld

gemiddeld

gemiddeld

hoog

hoog

laag

hoog

gemiddeld

erg hoog

hoog

laag

hoog

gemiddeld

gemiddeld

gemiddeld

gemiddeld

gemıddeld

laag

laag

erg laag

noog

MBO procestechniek

MBO brood en banket

MBO levensmiddelentechniek/vleesverwerking

$M B O$ vervoer en logistiek

MBO dokters-. tandarts-en dierenartsassistent

MBO apothekersassistent

$M B O$ verpleging

MBO gezondheidstechniek

MBO sociaal-cultureel

$M B O$ verzorging

MBO uiterlijke verzorging

MBO horeca

$M B O$ beweging en therapte

$M B O$ administratie

MBO handel

MBO secretariaat

gemiddeld

gemiddeld

laag

gemiddeld

laag

laag

13

erg hoog

erg hoog

laag

laag

erg hoog

gemiddeld

gemiddeld

hoog

hoog

gemiddeld

gemiddeld

gemiddeld

MBO toerisme en recreatie

hoog

MBO openbare orde en veiligheid

laag

Totaal

23

Bron: ROA 
Tabel 4.9

Indicator Toekomstige Arbeldsmarktperspectieven (ITA) en Indicator Toekomstige Knelpunten in de Personeelsvoorziening (ITKP) naar opleiding, Limburg, 1999-2004

\begin{tabular}{|c|c|c|c|c|}
\hline Opleudingstype & ITA & typering & ITKP & typering \\
\hline Basisonderwijs & 1,02 & redelijk & 1,23 & geen \\
\hline VMBO theorie & 0.94 & goed & 0.94 & groot \\
\hline VMBO landbouw en natuurlijke omgeving & 1.07 & matig & 1.37 & geen \\
\hline VMBO bouwtechniek & 1.07 & matig & 1.29 & geen \\
\hline VMBO installatietechniek & • & redelijk & - & geen \\
\hline VMBO metaal: mechanische techniek & 0,87 & goed & 1,14 & vrijwel geen \\
\hline VMBO voertuigentechniek & 1.04 & redelijk & 1,36 & geen \\
\hline VMBO elektrotechniek & 0,90 & goed & 1,02 & enige \\
\hline VMBO grafische techniek & - & goed & - & geen \\
\hline VMBO brood en banket & - & goed & - & geen \\
\hline VMBO consumptief en levensmiddelentechniek & - & matig & 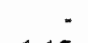 & geen \\
\hline VMBO transport en logistiek & 0,96 & goed & 1,15 & vrijwel geen \\
\hline VMBO administratse, handel en mode & 1,11 & matig & 1,15 & geen \\
\hline VMBO (uiterijjke) verzorging & 0,89 & goed & 0,89 & groot \\
\hline VMBO bevelliging & - & matig & - & vrijwel geen \\
\hline HAVONWO & 0,96 & goed & 0,96 & groot \\
\hline MBO landbouw en veeteelt & 0,84 & zeer goed & 0,84 & zeer groot \\
\hline MBO milieu en groene ruimte & - & goed & - & groot \\
\hline MBO laboratorium & - & matig & - & geen \\
\hline MBO bouw & 1,04 & redelijk & 1,06 & vrijwel geen \\
\hline MBO grond-, weg- en waterbouw & - & redelijk & - & vrijwel geen \\
\hline MBO installatietechniek & 1.11 & matig & 1,20 & geen \\
\hline MBO werktuigbouw en mechanische techniek & 1.00 & redelijk & 1,14 & vrijwel geen \\
\hline MBO fijnmechanische techniek & - & goed & - & vrijwel geen \\
\hline MBO motorvoertuigentechniek & 0,98 & goed & 1,03 & enige \\
\hline MBO vliegtuigtechniek & - & goed & - & vrijwel geen \\
\hline MBO operationele techniek & - & slecht & - & geen \\
\hline MBO elektrotechniek & 1,00 & goed & 1.05 & vrijwel geen \\
\hline MBO grafische techniek & 0,97 & goed & 1,19 & geen \\
\hline MBO procestechniek & 0.97 & goed & 0,97 & groot \\
\hline MBO brood en banket & - & goed & - & geen \\
\hline MBO levensmIddelentechniek/vleesverwerking & - & goed & - & groot \\
\hline MBO vervoer en logistiek & 0,92 & goed & 0.92 & groot \\
\hline MBO dokters- tandarts-en dierenartsassistent & - & matig & - & vrijwel geen \\
\hline MBO apothekersassistent & - & redelijk & - & enige \\
\hline MBO verpleging & 0,88 & goed & 0.88 & groot \\
\hline MBO gezondheidstechniek & & zeer goed & - & zeer groot \\
\hline MBO sociaal-cultureel & 1,06 & matig & 1,06 & vrijwel geen \\
\hline MBO verzorging & 0.95 & goed & 0,95 & groot \\
\hline MBO uiterlijke verzorging & 0,91 & goed & 0,91 & groot \\
\hline MBO horeca & 1.00 & goed & 1.00 & groot \\
\hline MBO beweging on therapie & 1.13 & matig & 1.13 & vrijwel geen \\
\hline MBO administratie & 1.00 & redelijk & 1.00 & enige \\
\hline MBO handel & 0,95 & goed & 0,95 & groot \\
\hline MBO secretariaat & 0.93 & goed & 0,93 & groot \\
\hline MBO toerisme en recreatie & - & redelijk & - & enige \\
\hline MBO openbare orde en veiligheid & 0,95 & goed & 0,97 & groot \\
\hline
\end{tabular}

Bron: ROA 
conjuncturu- typering gevoeligheid spreidingsindex typering

20.56

19,08

6.18

4,82

6,60

10,66

15.24

9.53

12.67

6.51

11,61

11,48

2,17

14,42

11.03

3.84

16,78

4,61

3,93

6,38

3,78

6.81

2,37

9,05

9.52

4,09

5.42

5.30

7.07

5.21

3.71

6.01

7.23

11.03

2.55

1,67

3.17

1,83

9,58

6.54

3.41

7.95

9.34

6.06

12.86

3,75

4,82

21,32

7,53

5.56

2,71

6,52

laag

hoog

hoog

hoog

hoog

hoog

hoog

hoog

laag

hoog

laag

laag

laag

laag

laag

laag

laag

laag

hoog

laag

laag erg hoog

erg hoog

gemiddeld

gemiddeld

gemiddeld

gemiddeld

erg hoog

gemiddeld

gemiddeld

erg laag

gemiddeld

gemiddeld

gemiddeld

gemiddeld

gemiddeld

erg laag

erg laag

erg laag

erg laag

gemiddeld

gemıddeld

erg laag

gemiddeld

gemiddeld

gemiddeld

erg hoog

gemiddeld

gemiddeld

gemiddeld

gemiddeld

laag erg hoog

gemiddeld

gemiddeld

erg laag

gemiddeld

Bron: ROA 